OCCASIONAL PAPER
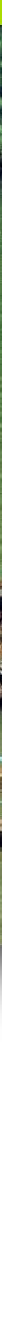

\title{
Forest use and timber markets in the Ecuadorian Amazon
}

Edited by

Elena Mejía

Pablo Pacheco
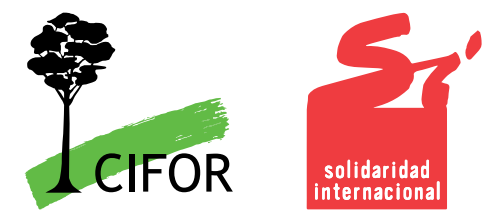



\section{Forest use and timber markets in the Ecuadorian Amazon}

Edited by

Elena Mejía

CIFOR

Pablo Pacheco

CIFOR 
Occasional Paper 111

(c) 2014 Center for International Forestry Research (CIFOR)

Content in this publication is under a Creative Commons Attribution-NonCommercial-NoDerivs 3.0 Unported License: http://creativecommons.org/licenses/by-nc-nd/3.0/deed.es

ISBN 978-602-1504-14-7

Mejía E and Pacheco P. 2014. Forest use and timber markets in the Ecuadorian Amazon. Occasional Paper 111. Bogor, Indonesia: CIFOR.

Translation of: Mejía E y Pacheco P. 2013. Aprovechamiento forestal y mercados de la madera en la Amazonía Ecuatoriana. Occasional Paper 97. Bogor, Indonesia: CIFOR.

Photos: Tomas Munita/CIFOR

Villagers make a timber raft to transport wood downstream on the Arajuno River, Ecuador.

This document has been produced with the financial assistance from the European Union through the EU--funded project PRO-FORMAL (http://www.cifor.org/proformal). The views expressed herein are those of the authors and can in no way be taken to reflect the official opinion of the European Union or CIFOR.

\author{
CIFOR \\ Jl. CIFOR, Situ Gede \\ Bogor Barat 16115 \\ Indonesia \\ $\mathrm{T}+62(251) 8622-622$ \\ $F+62(251) 8622-100$ \\ E cifor@cgiar.org
}

\title{
cifor.org
}

We would like to thank all donors who supported this research through their contributions to the CGIAR Fund. For a list of Fund donors please see: https://www.cgiarfund.org/FundDonors

Any views expressed in this book are those of the authors. They do not necessarily represent the views of CIFOR, the authors' institutions or the financial sponsors. 


\section{Contents}

List of acronyms vii

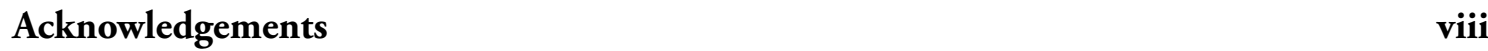

Introduction 1

Overview: Forestry sector and forest policies $\quad 4$

2.1 Land use, population and the forestry sector 4

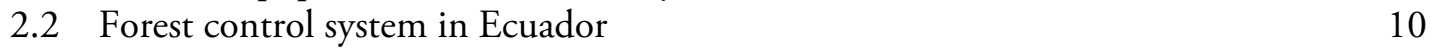

$\begin{array}{ll}2.3 & \text { Regulation and implementation costs } \\ & 11\end{array}$

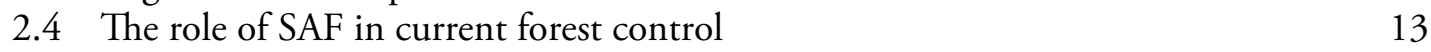

2.5 Implications of control on small-scale timber harvesting 15

$\begin{array}{ll}\text { Actors, intermediation and forest control in the Amazon } & \mathbf{1 6}\end{array}$

$\begin{array}{ll}3.1 \text { Characteristics of intermediation actors } & 16\end{array}$

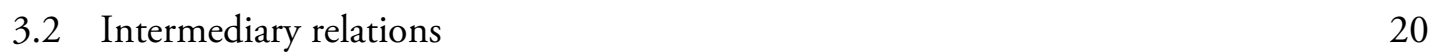

$\begin{array}{ll}3.3 & \text { Trust relations and conflicts with the authority } \\ 3.4 & 22\end{array}$

$\begin{array}{ll}3.4 & \text { Actors' strategies to evade the control system } \\ 3.5 & 23\end{array}$

$\begin{array}{ll}3.5 & \text { Evasion of other harvesting regulations } \\ 3.6 & 26\end{array}$

3.6 SAF effectiveness in the context of intermediation 27

Domestic timber market $\quad 28$

4.1 Timber harvesting per forest type and species $\quad 28$

4.2 Main timber trade flows $\quad 32$

4.3 A description of suppliers and buyers 38

4.4 Timber establishments in four cities 44

Timber harvesting by smallholders in Napo and Orellana $\quad 47$

5.1 The case of Napo: Analysis of smallholders' strategies 48

5.2 Differentiated strategies for timber harvesting $\quad 52$

$\begin{array}{ll}\text { 5.3 The case of Orellana: Analysis of smallholders' strategies } & 58\end{array}$

$\begin{array}{lll}5.4 & \text { Differentiated strategies for timber harvesting } & 61\end{array}$

5.5 Summary of findings with regards to timber harvesting by smallholders 66

Small-scale timber harvesting

6.1 Characteristics of timber operations and the actors involved 70

$\begin{array}{ll}\text { 6.2 Legality costs in timber harvesting programs } & 72\end{array}$

6.3 Decisions related to timber harvesting, productivity and quality 73

$\begin{array}{ll}\text { 6.4 Costs and benefits of small-scale timber harvesting } & 75\end{array}$

6.5 Comparison of smallholders' benefits 80

$\begin{array}{lr}\text { Conclusions } & 82\end{array}$

$\begin{array}{lr}\text { References } & 85\end{array}$

$\begin{array}{lr}\text { Annex } & 89\end{array}$ 


\section{List of tables, figures, maps and boxes}

\section{Tables}

1. Land use in agricultural production units in $2010 \quad 6$

2. Changes in the rural population of Ecuador for 2001-2010 6

3. Economic indicators for selected years (in USD million) 7

4. Main origins, types of forest and timber destination 8

5. Improvements from SAF I to SAF II at user level 13

6. Payments for the legalization of standing trees or foothill forests

$\begin{array}{ll}\text { 7. Key informants interviewed } & 17\end{array}$

8. Typology of intermediaries 18

9. Type of executor $\quad 18$

10. Type of intermediaries and payments made to the smallholder 19

11. Conflict between actors in timber harvesting 22

12. Difference in land use change after a PAFSI 25

13. Forest use by region and forest type in 2011 (in thousand $\mathrm{m}^{3}$ ) 29

14. Amazon: Use by type of program in 2011 (in thousand $\mathrm{m}^{3}$ ) 29

15. Amazon: Use by type of program and species in 2011

16. Ecuador: Destination and origin of the mobilized timber in 2011

17 Main mobilized species in the Amazon and their destinations 34

18. Executors by category and size 39

19. Buyers by size and category 39

20. Type of forest program executors and buyers according to category in $2011 \quad 40$

21. Executors by category and buyers by size $\quad 42$

22. Amazon: Type of forest program executors and buyers according to category in $2011 \quad 43$

23. Amazon: Executors by category and buyers by size 44

24. Comparison of purchase and processing volumes 46

25. Characteristics of colonist and Kichwa households 48

26. Land use (in hectares) in colonist and Kichwa plots 49

27. Deforestation in Kichwa and colonist plots for 2006-2012 50

28. Kichwa and colonist income for August 2011-September $2012 \quad 50$

29. Description of forest income from timber and non-timber products for
August 2011-September 2012

30. Characteristics of the different groups of households according to their timber
harvesting strategies

31. Harvesting characteristics according to predominant type 54

32. Characteristics of the sale of timber according to the form of harvesting 55

33. Characteristics of the amount of timber sold with and without a harvesting program and according to ethnic groups and harvesting strategies in Napo between 2011 and $2012 \quad 55$

34. Costs and benefits of small smallholders for August 2011-September 2012 (in USD) 56

35. Harvesting by type of species and land use (in m3) 57

36. Characteristics of colonist, Kichwa and Shuar households 58

37. Land use in hectares in colonist and indigenous (Kichwa and Shuar) plots 59

38. Deforestation in Kichwa and colonist plots for 2006-2012 59

39. Colonist and indigenous (Kichwa and Shuar) income for February 2011-July $2012 \quad 60$ 
40. Description of forest income from timber and non-timber products for

February 2011-July 2012

41. Types according to household attributes and the strategy of forest resources harvesting 62

42. Characteristics of harvesting by form of harvesting

43. Characteristics of the sale of timber according to the form of harvesting

44. Characteristics of the amount of timber sold with and without a harvesting program according to ethnic groups and harvesting strategies in Orellana

45. Costs and benefits of small smallholders for February 2011-July 2012 (in USD)

46. Use by type of species and land use $\left(\right.$ in $\left.\mathrm{m}^{3}\right)$

47. Comparative information between Napo and Orellana

48. Identified types and number of selected cases ${ }^{\text {a }} 70$

49. Characteristics of the operations 71

50. Costs associated with timber legalization in USD 72

51. Legalization costs in the area under study for different volumes of harvested timber $\quad 73$

52. Differences between average waste of cutting and sawing 74

53. Average yield in studied species 75

54. Average costs and sale price of harvested species (in USD $/ \mathrm{m}^{3}$ ) 76

55. Average costs and sale prices of harvested species in the case studies (in USD/product) 78

\section{Figures}

1. Timber harvesting by forest formation between 2007 and $2011\left(\mathrm{~m}^{3}\right)$.

2. Amazon: Legalization costs in the period 2005-2012 (in USD $/ \mathrm{m}^{3}$ ).

3. Forest control system, based on information gathered in the web page of the Ministry of Environment of Ecuador.

4. Intermediaries in timber trade, based on information obtained from interviews between May and September 2012.

5. Amazon: Harvested volume (in $\mathrm{m}^{3}$ ) by forest type and province.

6. Amazon: Transported timber according to province of origin and 10 main destinations (thousand $\mathrm{m}^{3}$ ).

7. Transported volume by executor size and forest formation (thousand $\mathrm{m} 3$ ). 41

8. Transported volume by buyer size and forest formation (thousand $\mathrm{m}^{3}$ ). 41

9. Main suppliers of timber of the interviewed establishments. 45

10. Main buyers of timber of the interviewed establishments. 45

11. Role of forestry income in family security mechanisms in crisis or contingency situations. 51

12. Percentage of the total cost for August 2011-September 2012.

13. Role of forestry income in family security mechanisms in crisis or contingency situations. 61

14. Percentage of the total cost for February 2011-July 2012.

15. Distribution of costs per cubic meter by item and smallholders' share for eight case studies of small-scale timber harvesting with and without PAFSI (in USD).

16. Difference of income and costs between formal and informal artisanal operations with smallholder or intermediary intervention $\left(\mathrm{USD} / \mathrm{m}^{3}\right)$.

17. Distribution of benefits among harvesting actors $\left(\mathrm{USD} / \mathrm{m}^{3}\right)$. Personal compilation based on field data gathered between March and August 2012.

\section{Maps}

1. Geographic area of study and location of the surveyed communities. 2

2. Land use cover in Ecuador by region and province. 5

3. Ecuador: Timber trade at the province level elaborated according to data from SAF, Ministry of Environment of Ecuador (2011)

4. Amazon: Major timber trade flows at the province level, elaborated according to information from SAF, Ministry of Environment of Ecuador (2011).

5. Origin of timber with final destination in Huaquillas, elaborated according to information from SAF, Ministry of Environment of Ecuador (2011). 


\section{Boxes}

1. Timber "laundering" process 23

2. Land use change after PAFSI implementation 25

3. Trade of timber with final destination in Huaquillas 35

4. Chainsaw operators in timber harvesting 74

5. Participation of women in forest harvesting activities: Invisible labor-Kichwa women 77 


\section{List of acronyms}

CAPEIPI Chamber of Small and Medium-sized Enterprises of Pichincha (Cámara de la Pequeña y Mediana Empresa de Pichincha)

CAPIA Chamber of Small Industries of Azuay (Cámara de la Pequeña Industria del Azuay)

CLIRSEN Centre for the Integrated Surveying of Natural Resources by means of Remote Sensing (Centro de Levantamientos Integrados de Recursos Naturales por Sensores Remotos)

DNF National Forestry Directorate (Dirección Nacional Forestal)

FAO Food and Agriculture Organization of the United Nations

FCB Balsa Logging Form (Formulario de Corta para Balsa)

FCP Pigüe Logging Form (Formulario de Corta para Pigüe)

ITTO International Tropical Timber Organization

MAE Ministry of Environment of Ecuador (Ministerio del Ambiente del Ecuador)

PAFAP Forest Harvesting Plan for Planted Trees (Programa de Aprovechamiento Forestal para Árboles Plantados)

PAFCL Forest Harvesting Program for Legal Land Conversion (Programa de Aprovechamiento Forestal en Conversión Legal)

PAFEP Forest Harvesting Program for Planted Forests (naturally regenerating trees) / Logging Program for Pioneer Species (Programa de Aprovechamiento Forestal para Bosques Cultivados (árboles de regeneración natural) / Programa de Corta de Especies Pioneras)

PAFPL Forest Harvesting Program for Planted Forests (Programa de Aprovechamiento Forestal para Bosques Cultivados)

PAFSI Simplified Forest Harvesting Plan (Plan de Aprovechamiento Forestal Simplificado)

PAFSU Sustainable Forest Harvesting Plan (Plan de Aprovechamiento Forestal Sustentable)

PCAR Logging Program for Relict Trees (Programa de Corta para Corta de Árboles Relictos)

SAF Forest Administration System (Sistema de Administración Forestal)

SCF Forest Control System (Sistema de Control Forestal)

SENPLADES National Secretariat of Planning and Development (Secretaría Nacional de Planificación y Desarrollo | Ecuador)

SGS Société Générale de Surveillance

SNDCF Decentralized National Forest Control System (Sistema Nacional Descentralizado de Control Forestal)

SNTCF Outsourced National Forest Control System (Sistema Nacional Terciarizado de Control Forestal)

SRI Internal Revenue Service (Servicio de Rentas Internas del Ecuador) 


\section{Acknowledgements}

The authors wish to thank the valuable collaboration of several people who have contributed in the process of information compilation, mainly in the provinces of Napo and Orellana, without whom the elaboration of this study would not have been possible. Our acknowledgement is mainly directed to members of the Kichwa, Shuar and mestizo communities in these provinces. We further acknowledge the Ministry of Environment (Ministerio del Medio Ambiente, MAE), both at its Quito office as in Napo and Orellana offices for the support they offered with information and discussions that have contributed to improve our analysis. We would also like to thank GIZ Ecuador for its support throughout the research process, as well as the State Technical University of Quevedo (Universidad Técnica Estatal de Quevedo) and the Technical University of the North (Universidad Técnica del Norte). This research would not have been possible without the financial support of the European Union. This research was carried out as part of the CGIAR Research Program on Forests, Trees and Agroforestry (CRP-FTA), a collaborative program aimed at enhancing the management and use of forests, agroforestry and tree genetic resources across the landscape from forests to farms. 


\section{Introduction}

Several studies have analyzed the situation of the forestry sector in Ecuador, with different focus. For instance, Owen and Thiel (2006) assess the influence of policies on the economic dynamics of the forestry sector. Ibarra et al. (2008) explore the implications of forestry legislation in small-scale forest management by smallholders. Añazco et al. (2010) adopt a more comprehensive perspective to consider the current problems faced by the forestry sector and indicate the challenges to advance towards sustainable forest management. Unlike these, the analysis here is centered in the dynamics of timber harvesting in the Amazon undertaken by smallholders, colonists and indigenous people, and their relations with the domestic timber market. The most relevant studies on related issues were focused on describing the internal uses and trade flows of timber (Wunder, 1996), as well as the timber value chains with a national perspective (Ministerio del Ambiente del Ecuador, 2011).

This document is part of a broader comparative study that explores options to articulate into the formal timber sector a relatively large sector of small-scale timber producers, linked to the domestic market, that usually undertake their harvesting operations informally. This is a relevant issue in Ecuador since an important part of timber harvesting in native forests, particularly in the Amazon, is carried out with chainsaws in small size plots that are under control of smallholders and indigenous communities. Likewise, a significant amount of timber is harvested, for several reasons, outside any forest regulation, which has several implications on smallholder' livelihoods and the forestry sector's economy. For a better insight into the persistence and implications of informal timber harvesting, it is important to understand the characteristics of the timber operations, the conditions under which these operations take place, the interactions between the different actors, and the arrangements for benefit sharing.
The analysis here provides elements that highlight the importance of the domestic market and smallscale timber harvesting, and the legal, institutional and economic conditions that shape this type of forest use. In addition, the efforts made in Ecuador to improve governance conditions in the forest sector are worth highlighting, particularly those aimed at simplifying the forest regulations and the implementation of a system for verification of forest legality associated with a forestry advisory scheme (by independent forestry advisors) as well as controls in the different stages of the value chain. Ecuador, unlike other countries in the Amazon basin, does not penalize timber harvesting with chainsaws. These efforts have been decisive to advance towards more sustainable forest management, but better options are still needed in order to integrate smallholders into the formal domestic timber market.

The remaining challenges are related to the need to reduce the institutional barriers that make it difficult for a group of small producers to conduct formal harvesting operations, through continue adapting the forest regulations to the needs of smallholders and indigenous populations. In addition, it is important to improve the distribution of the economic benefits between the different actors that participate in the harvesting, which can probably be achieved by providing improved financial services to the local forest users, as well as by enhancing transparency in timber markets. In this sense, it is important to transition from a vision that gives priority to forest control to another that also encourages sustainable forest use practices but within more integrated perspectives of agricultural land, forests and landscapes management.

The analysis here focuses on different levels. Chapter 2 introduces the main elements of the context of forest governance in Ecuador. Chapter 3, which complements the previous one, is based 
on interviews to key agents in the domestic timber market, mainly timber producers and intermediaries in the provinces of Orellana and Napo. It also describes how these actors relate to the markets, their arrangements, and the implications for forest control. Chapter 4 focuses on national dynamics of timber harvesting and the main timber flows according to official statistics from the Forest Administration System (SAF for its acronym in Spanish) of the Ministry of Environment(MAE for its acronym in Spanish), which covers legal timber flows. Chapter 5 is centered in the provinces of Orellana and Napo and is based on data from household surveys for a better understanding of their decisions of land use and forest management as part of more general livelihood strategies. This analysis is complemented by case studies on the different forms of timber harvesting operations and benefit distribution associated with these different types of timber operations (chapter 6).

The analysis of intermediation networks in formal and informal harvesting in chapter 3 is based on interviews to the different actors that take part in timber harvesting and marketing, including: traders, intermediaries, forestry advisors, forestry technicians, chainsaw operators, and community authorities. The more general analysis on the dynamics of domestic timber markets in chapter 4 is based on official SAF information provided by MAE for 2011, the last year with available data from SAF at the time of the analysis. This information only presents timber mobilization by origin and destination with legal origin, i.e. they have a permit for timber harvesting and transport permits, so it does not reflect informal timber flows. In spite of this limitation, since the data only presents the legal part of the overall harvested volume, they provide a relatively complete picture of the volumes mobilized along the main timber roads and to the most important consumption centers. This information is complemented by other information that can be publicly accessed from the Internal Revenue Service (SRI for its acronym in Spanish) to determine the types of harvesting program implementers and buyers in accordance with their Single Tax Payer Registry (RUC for its acronym in Spanish). The combination of these data makes it possible to offer a more complete perspective regarding the main characteristics of timber trade flows associated with the different types of timber sellers and buyers for Ecuador as a whole.

Chapter 5 discusses smallholders' decisions on land use and forest management. It is based on 243 semistructured household surveys in 21 communities located in the provinces of Orellana and Napo. The

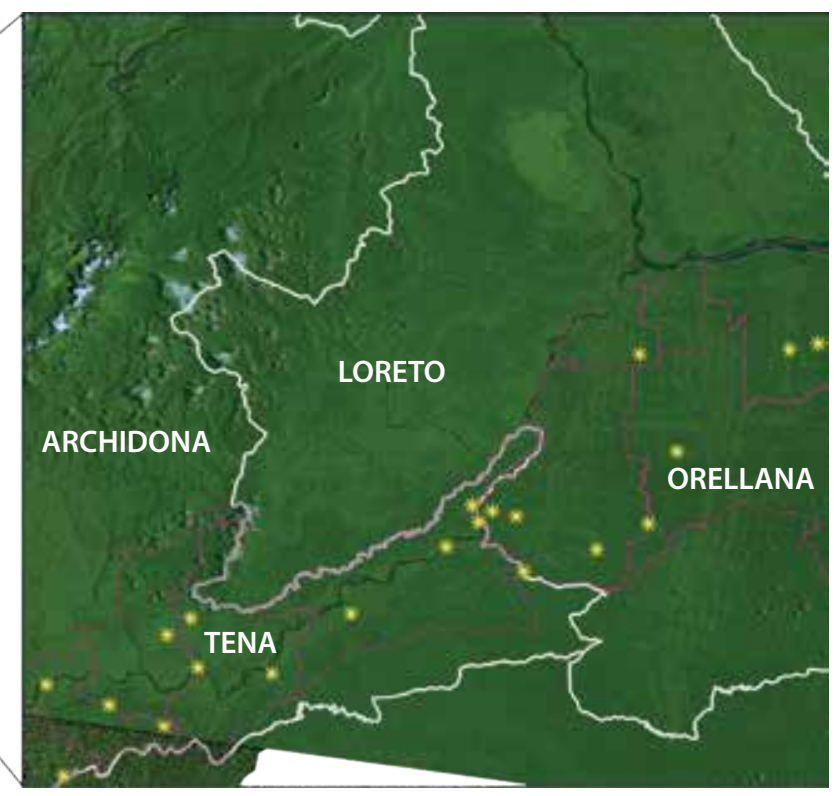

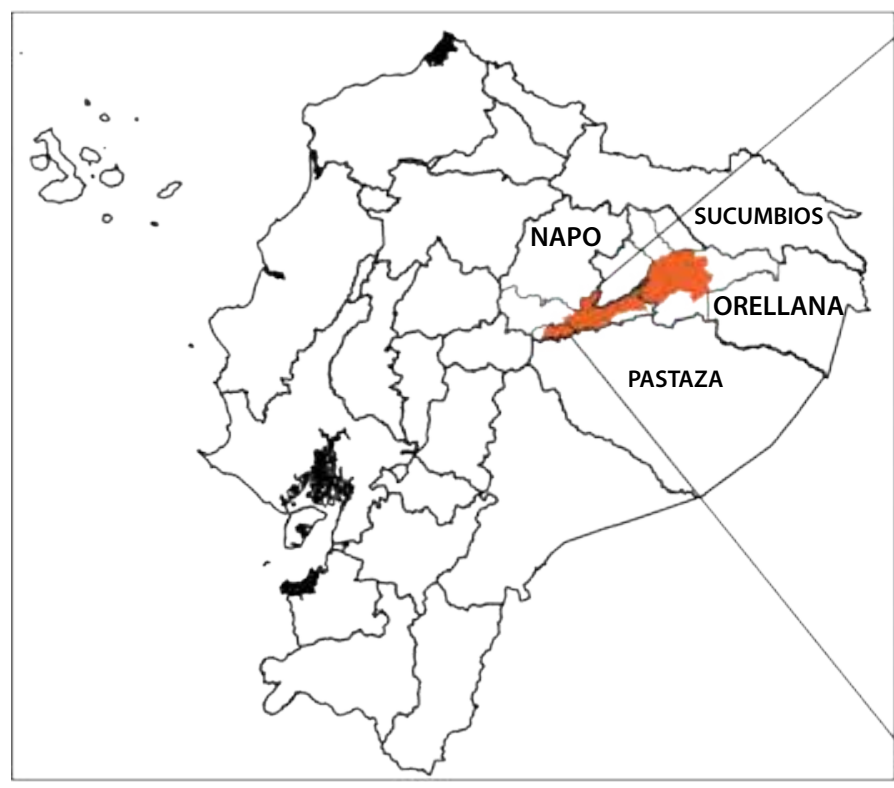

Map 1. Geographic area of study and location of the surveyed communities. The yellow stars correspond to selected communities and the red lines to the parishes where the study was carried out. Personal compilation based on the information of the technical office of MAE in the province of Napo. 
household selection was made in two stages: first, the communities were identified by purposive sampling based on communities' ethnic origin, size and location, and afterwards, the households to be interviewed were identified by simple random sampling. Field data were collected for seven months from February to September 2012. Map 1 provides details of the location of the communities selected for information gathering. In turn, the analysis of forest harvesting operations in chapter 6 is based on eight selected case studies in the provinces of Orellana and Napo according to a typology that considers the legality of the harvesting and smallholder participation in timber logging. The methods for data collection were based on the monitoring of logging operations by intermediaries and smallholders, where productivity and cost/benefit information was gathered. This study was conducted from March to August 2012. 


\title{
Overview: Forestry sector and forest policies
}

\author{
Elena Mejía and Pablo Pacheco
}

\subsection{Land use, population and the forestry sector}

The Republic of Ecuador has an area of $256,370 \mathrm{~km}^{2}$. It has four clearly differentiated geographical regions, namely: the coast (Costa) along the Pacific coastline of the country, the Highlands (Sierra) covering the Andean mountain range going across the center of the country north to south, the east (Oriente) involving the lowlands in the Amazon region, and the island region of Galapagos islands. The country is administratively divided into 24 provinces, which in turn are divided into cantons and parishes. The Amazon is the largest region, taking up $45 \%$ of the overall area of the country $\left(115,613 \mathrm{~km}^{2}\right) .{ }^{1}$ This region is comprised of lowlands that are mostly covered with dense tropical forests stretching to the bottom of the Andes, with vegetation containing important biodiversity (Map 2).

The vegetation cover in Ecuador strongly depends on the geographical regions. In the Amazon, native forests prevail, home to great biodiversity (Mena, et al., 2011). Over time, forests have been reduced, although information on this trend is mixed. A study performed by CLIRSEN (2003) states that forest cover was 11.68 million hectares in 2000 . FAO (2010) estimated forest cover at 11.84 million hectares for the same year, which seems to have been reduced to 9.86 million hectares in 2010. Nevertheless, these data consider a linear growth in deforestation of 197,000 hectares/ year between 1990 and 2010, which resulted in annual deforestation rates of around $1.5 \%$. However, according to a study by the Ministry of Environment of Ecuador (Ministerio del Ambiente del Ecuador, 2012), recent deforestation is significantly lower, since it was 89,900 hectares

1 The Ecuadorian Amazon encompasses six provinces (north to south): Sucumbíos, Orellana, Napo, Pastaza, Morona Santiago and Zamora Chinchipe. in $1990-2000(0.71 \%$ year $)$ and 77,600 hectares between $2000-2008$ (0.66\% year). According to this source, the Coast has the highest deforestation rate, then the Andes eastern hillside, followed by the Amazon.

There is partial information on land uses in territories occupied by agricultural landholdings. According to the Survey of Surface and Continuous Agricultural Production (ESPAC for its acronym in Spanish), over a total area of 11.74 million hectares taken up by agricultural landholdings ${ }^{2}$, the largest areas were intervened in the Highlands and in the Coast. It is not surprising that the main land uses in these landholdings are associated with permanent and temporary crops, but especially pastures, which take up almost half of the overall area. Besides, agricultural landholdings in the Amazon region alone account for more than half of the forest area $(55 \%)$, a proportion that is lower in the Highlands $(27.5 \%)$ and Coast (21.7\%) (Table 1). INEC's last Agricultural Census (2011) estimates that $85 \%$ of the Amazon population depends on agriculture ${ }^{3}$.

The intervention and use of natural resources, which has an influence on land use, is strongly associated with the intensity of human occupation in different regions, as can be seen in Table 2. The Highlands is the most populated region, with a net absolute growth in population, with high density due to agricultural land use. Population in the

2 Provinces are the economic units with a land extension of $500 \mathrm{~m}^{2}$ or more, totally or partly devoted to agricultural production, which develop their activities under a directorate or single management irrespective of their form of tenure or INEC geographical location. 2010. ESPAC methodological synthesis. Quito, Ecuador: National Institute of Statistics and Censuses (Instituto Nacional de Estadísticas y Censos, INEC).

3 The National Development Bank (Banco Nacional de Fomento) grants $70 \%$ of loans for agricultural purposes, 55\% of which are destined for livestock purchase and 35\% for permanent crops. 


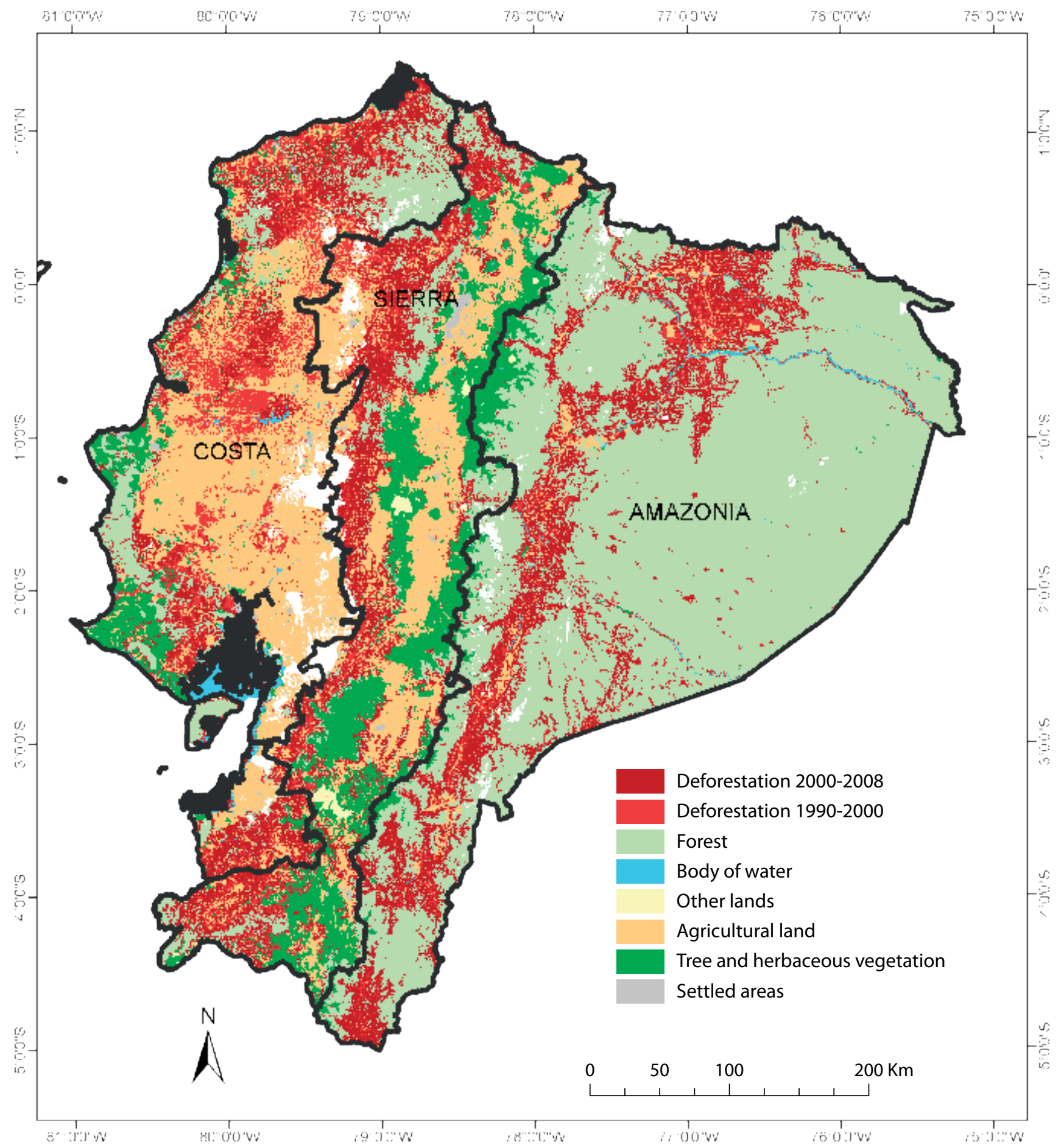

Map 2. Land use cover in Ecuador by region and province. The information of soil use comes from the analysis of the deforestation baseline elaborated by the Ministry of Environment (MAE 2012). The Galápagos Islands are not included.

Coast tends to decrease in absolute terms, which consequently reduces the share of rural population to almost one fourth of the total population in 2010. In spite of this, the population density due to land use has remained over time, also because of the slow expansion of crop land uses in this region in absolute terms. Finally, the Amazon region undergoes a higher growth in rural population, yet rural population tends to decrease in relative terms due to a higher growth rate in the urban population. The population per unit of cultivated area also tends to increase in relative terms in this region (Table 2). 
Table 1. Land use in agricultural production units in 2010

\begin{tabular}{|c|c|c|c|c|c|c|}
\hline & Crops & Pastures & Moorlands & Forests & Other uses & Total (a) \\
\hline \multicolumn{7}{|c|}{ Land use by region (in thousand ha) } \\
\hline Highlands & 769 & 2135 & 502 & 1176 & 98 & 4679 \\
\hline Coast & 1641 & 1882 & 2 & 44 & 105 & 4573 \\
\hline Amazon & 155 & 904 & 36 & 1385 & 14 & 2493 \\
\hline Total & 2565 & 4920 & 539 & 3504 & 217 & 11745 \\
\hline \multicolumn{7}{|c|}{ Percentage by row } \\
\hline Highlands & 18.9 & 49.5 & 1.4 & 27.5 & 2.7 & 100 \\
\hline Coast & 33.6 & 42.6 & 0 & 21.7 & 2.1 & 100 \\
\hline Amazon & 6 & 36.2 & 1.6 & 55.3 & 1 & 100 \\
\hline Total & 22 & 43.7 & 0.9 & 31.4 & 2.1 & 100 \\
\hline
\end{tabular}

Note: a) Totals have been adjusted to correct errors observed in the original data base.

Source: Data obtained from Ecuador en Cifras (http://www.ecuadorencifras.com), Area and Continuing Agricultural Production Survey (Encuesta de Superficie y Producción Agropecuaria Continua, ESPAC), INEC (2011).

Table 2. Changes in the rural population of Ecuador for 2001-2010

\begin{tabular}{lccccccc}
\hline \multirow{2}{*}{ Region $^{\mathrm{a}}$} & \multicolumn{2}{c}{$\begin{array}{c}\text { Rural population } \\
\text { (thousand) }\end{array}$} & $\begin{array}{c}\text { Change in rural } \\
\text { population (\%) }\end{array}$ & $\begin{array}{c}\text { Rural population/ } \\
\text { total (\%) }\end{array}$ & $\begin{array}{c}\text { Rural population/ } \\
\text { total agricultural area } \\
\text { (inhabitants/ha) }\end{array}$ \\
\cline { 2 - 8 } & 2001 & 2010 & $2001-2010$ & 2001 & 2010 & $\mathbf{2 0 0 1}$ & 2010 \\
\hline Highlands & 2448 & 2487 & 1,6 & 44.8 & 39.9 & 0.85 & 0.86 \\
Coast & 1849 & 1820 & $(1,6)$ & 30.5 & 26.0 & 0.52 & 0.52 \\
Amazon & 354 & 390 & 9.4 & 64.5 & 55.1 & 0.33 & 0.37 \\
Total & 4650 & 4697 & 1.0 & 38.5 & 33.7 & $\mathbf{0 . 6 2}$ & $\mathbf{0 . 6 3}$ \\
\hline
\end{tabular}

Source: Data obtained from Ecuador en Cifras (http://www.ecuadorencifras.com), Area and Continuing Agricultural Production Survey (Encuesta de Superficie y Producción Agropecuaria Continua, ESPAC), INEC (2011).

Ecuador has a relatively vigorous economy, which relies strongly on oil exploration and exports. In 2011, total GDP rose to around USD 78 billion, most of which are associated with the oil and manufacturing sectors. The contribution of the agricultural, livestock and forestry sectors to total GDP is around 9-9.5\% between 2007 and 2011 (Table 3). The contribution of the forestry sector to total GDP is unknown; however, Owen and Thiel (2006) estimated that it reached $1 \%$ of GDP in 2006, a trend that may have remained in the following years.

The low contribution of the forestry sector to the overall economy, in relative terms, is also reflected in the export structure, given that forestry exports only reach $1 \%$ of total exports (Banco Central del Ecuador, 2012). They amounted to USD 148 million in 2007 and USD 228 million in 2011. Nevertheless, forest product imports are relatively fewer, although they have tended to increase, amounting to USD 58 million in 2011. The limited importance of imports in Ecuador results in a positive forest trade balance (excluding pulp, paper and cardboard). In spite of its limited formal contribution to the domestic economy, the forest industry in Ecuador has a key role in income and job creation.

The forestry sector in Ecuador is mainly oriented towards the domestic market, although the briquette and plywood industry is intended for foreign markets (Sierra, 2001). Although the native forests of the Coast were the main source of timber in the past, due to their gradual reduction over time, this supply has been replaced by forest 
Table 3. Economic indicators for selected years (in USD million)

\begin{tabular}{|c|c|c|c|c|c|}
\hline & 2007 & 2008 & 2009 & 2010 & 2011 \\
\hline \multicolumn{6}{|l|}{ Gross domestic product (GDP) } \\
\hline Total GDP & 51008 & 61763 & 61550 & 67856 & 78189 \\
\hline GDP agriculture and forestry & 4772 & 5537 & 5807 & 6427 & 7189 \\
\hline GDP agriculture and forestry/total (\%) & 9.4 & 9.0 & 9.4 & 9.5 & 9.2 \\
\hline \multicolumn{6}{|l|}{ Foreign trade } \\
\hline Total exports & 13800 & 18818 & 13863 & 17490 & 22345 \\
\hline Forestry exports & 148 & 176 & 155 & 206 & 228 \\
\hline Forestry exports/total (\%) & 1.1 & 0.9 & 1.1 & 1.2 & 1 \\
\hline Forestry imports & 24 & 36 & 37 & 52 & 58 \\
\hline Forestry trade balance & 124 & 139 & 118 & 154 & 170 \\
\hline
\end{tabular}

Source: Own elaboration based on ECLAC (2011) and COMTRADE (2011).

plantations established in the same region as well as in the Highlands. Although the contribution in relative terms of native forests to timber domestic supply is not significant and tends to diminish over time, the supply of timber from native forests in absolute terms has increased gradually, though slowly. This is partly accounted for by the greater road integration in the Amazon, which facilitates access to native forests, together with the expansion of urban demand, which has also fostered consumption of timber from native forests (Wunder, 2005; Barbieri, et al., 2009).

The domestic timber market in Ecuador is quite vigorous, with multiple timber trade flows between production and consumption areas, as have been described by the Ministry of Environment of Ecuador (2011). Table 4 presents some of the characteristics of the sector at a national level. There are not many reliable data on the timber volumes harvested before 2007. Official estimates suggest that the volumes of authorized timber have increased over time, ranging from 2.2 to 2.8 million $\mathrm{m}^{3}$ between 2007 and 2011 . Figure 1 shows the magnitude of forest use in the different regions of Ecuador for this period. It is worth highlighting that most timber authorizations have been granted to forest plantations, followed by those issued for native forests, farms in agroforestry systems and pioneer formations. Between 2007 and 2011 , on average, approximately $49.8 \%$ of the harvesting was authorized in the Coast, whereas about $33.7 \%$ and $16.4 \%$ was authorized in the Highlands and the Amazon, respectively.
Further, the construction sector contributed 2.338 billion to the national GDP in 2010 (Banco Central del Ecuador, 2012); especially in the cities of Guayaquil and Quito, where the timber demand is also concentrated, as shown by the SAF data analyzed here. Since 2010, the real estate sector has soared, thus increasing timber demand for doors, floors and windows; however, it is unknown whether timber originates from legal supply. It is important to highlight that until 2000, according to ITTO (2002), there was an excess of demand for and limited supply of timber. Currently, it is believed that forest plantations have started to meet this demand as indicated by the trends in this chapter and in the ITTO 2011 country report. However, this has not meant that native forest timber harvesting has declined. For example, harvesting of species like chuncho, seike (Cedrelinga cateiniforme) used for doors and floors has increased.

Middleton (2007) argues that small-scale artisanal production in the forestry sector in Ecuador is disappearing from the market due to competition from the industry for timber supplies from intermediaries ${ }^{4}$ (depots). According to this author, artisan producers prefer local networks - generally informal ones-from which they obtain timber for their work; however, furniture imports from Brazil and Chile, along with large-scale timber industries, make domestic prices not competitive for them.

4 This observation was also made in the printed version of The Economist "The courts versus the rainforest". Available at http://www.economist.com/node/2180363 
Table 4. Main origins, types of forest and timber destination

\begin{tabular}{|c|c|c|c|c|c|}
\hline Place & Forest type & $\begin{array}{l}\text { Primary } \\
\text { processing }\end{array}$ & Primary industry & Secondary industry & Market \\
\hline \multirow{4}{*}{$\begin{array}{l}\text { Northern } \\
\text { Amazon } \\
\text { (Sucumbíos } \\
\text { and Orellana) }\end{array}$} & \multirow[t]{2}{*}{ Native forest } & Sawn timber & Sawmill & $\begin{array}{l}\text { Woodworking, } \\
\text { furniture making, } \\
\text { broom factory }\end{array}$ & $\begin{array}{l}\text { Local-national } \\
\text { Colombia-Peru } \\
\text { border. }\end{array}$ \\
\hline & & Roundwood & Plywood industry & $\begin{array}{l}\text { Woodworking, } \\
\text { furniture making, } \\
\text { broom factory }\end{array}$ & $\begin{array}{l}\text { National } \\
\text { International }\end{array}$ \\
\hline & \multirow[t]{2}{*}{$\begin{array}{l}\text { Plantation } \\
\text { Pioneer } \\
\text { formations } \\
\text { Agroforestry }\end{array}$} & Roundwood & $\begin{array}{l}\text { Plywood industry } \\
\text { Balsa sawmill } \\
\text { Pallet factory } \\
\text { Sawmill-depot }\end{array}$ & $\begin{array}{l}\text { Artisanal industry } \\
\text { Depot and } \\
\text { assembly plant }\end{array}$ & International \\
\hline & & Sawn timber & $\begin{array}{l}\text { Pallet factory } \\
\text { Sawmill-depot }\end{array}$ & $\begin{array}{l}\text { Depot and } \\
\text { assembly plant } \\
\text { Woodworking and } \\
\text { furniture making }\end{array}$ & Local-national \\
\hline \multirow[t]{3}{*}{$\begin{array}{l}\text { Central } \\
\text { Amazon } \\
\text { (Napo and } \\
\text { Pastaza) }\end{array}$} & \multirow[t]{2}{*}{ Native forest } & Roundwood & $\begin{array}{l}\text { Balsa sawmill (fixed- } \\
\text { portable) } \\
\text { Plywood industry } \\
\text { Fruit box factory } \\
\text { Pallet factory } \\
\text { Sawmill-depot }\end{array}$ & $\begin{array}{l}\text { Depot and } \\
\text { assembly plant }\end{array}$ & National \\
\hline & & Sawntimber & Sawmill-depot & $\begin{array}{l}\text { Wood working and } \\
\text { furniture making }\end{array}$ & Local-national \\
\hline & $\begin{array}{l}\text { Plantation } \\
\text { Pioneer } \\
\text { formations } \\
\text { Agroforestry }\end{array}$ & Sawntimber & $\begin{array}{l}\text { Sawmill-depot } \\
\text { Fruit box factory } \\
\text { Pallet factory }\end{array}$ & $\begin{array}{l}\text { Wood working and } \\
\text { furniture making }\end{array}$ & Local-national \\
\hline \multirow{4}{*}{$\begin{array}{l}\text { Southern } \\
\text { Amazon } \\
\text { (Morona } \\
\text { Santiago- } \\
\text { Zamora } \\
\text { Chinchipe) }\end{array}$} & \multirow[t]{2}{*}{ Native forest } & $\begin{array}{l}\text { Sawn timber } \\
\text { (land-river } \\
\text { transport) }\end{array}$ & Sawmill & $\begin{array}{l}\text { Woodworking and } \\
\text { furniture making } \\
\text { Broom factory }\end{array}$ & $\begin{array}{l}\text { Local-national } \\
\text { Colombia-Peru } \\
\text { border }\end{array}$ \\
\hline & & $\begin{array}{l}\text { Roundwood } \\
\text { (land-river } \\
\text { transport) }\end{array}$ & $\begin{array}{l}\text { Plywood industry } \\
\text { Furniture industry }\end{array}$ & & Local-national \\
\hline & \multirow[t]{2}{*}{$\begin{array}{l}\text { Plantation } \\
\text { Pioneer } \\
\text { formations } \\
\text { Agroforestry }\end{array}$} & Roundwood & $\begin{array}{l}\text { Balsa sawmill (fixed- } \\
\text { portable) } \\
\text { Fruit box factory } \\
\text { Pallet factory } \\
\text { Sawmill-depot }\end{array}$ & $\begin{array}{l}\text { Artisanal } \\
\text { Depot }\end{array}$ & $\begin{array}{l}\text { Local-national } \\
\text { International }\end{array}$ \\
\hline & & Sawn timber & $\begin{array}{l}\text { Sawmill-depot } \\
\text { Fruit box factory }\end{array}$ & $\begin{array}{l}\text { Woodworking and } \\
\text { furniture making } \\
\text { Depot and } \\
\text { assembly plant }\end{array}$ & Local-national \\
\hline
\end{tabular}


Several studies highlight the importance of replacing native forest with plantations (Izko, 2009; PNC-ONU-REDD Ecuador, 2013). Timber harvesting at the national level tended to increase proportionately in all forest formations in 2010 and 2011 (Figure 1). Although there is a clear long-term trend to reduce pressure on native forests through increased supply of timber from plantations and pioneer formations, simultaneously, the authorized volumes of native forests, especially in the Amazon, have tended to remain stable or increase slightly, which could be due to the fact that there are no plantations that could substitute the demand for native forest species.

Forest plantations cover an estimated area of 220,000 hectares (Ecuador Forestal, 2007). Around two thirds of them consist of pine (Pinus sp.) and eucalyptus (Eucalyptus sp.) plantations which are located in the Highlands, while those located in the Coast are composed of a greater diversity of species such as balsa Ochroma pyramidale, teak Tectona sp., melina Gmelina sp. and laurel Cordia alliodora (Owen and Thiel, 2006).

With the improvement recently seen in roads infrastructure in Ecuador, market integration, particularly in the case of the Amazon, between the production zones and the main urban markets has improved. Sector policies have had strong influence on increasing the pressures on forests, especially in the Amazon region, due to oil and mining exploitation and the expansion of the road system by provincial, municipal and the central government, which have somehow fostered the arrival of colonist immigrants and promoted the conversion of forests to agricultural land (Thiel and Trelles, 2008). In addition, greater property fragmentation may have led to an increase in the pressure on forests (Holand, et al., 2013).

In Ecuador, the overall timber demand and supply is not well known since official data only cover timber from authorized harvesting operations. Although SAF records timber volumes originated in legal sources, informally marketed volumes are unknown. The timber market combines timber from formal and informal harvesting. Regarding prices, apart from the estimates of the Ministry of Environment of Ecuador (2011), official prices are unknown. Likewise, the seasonality of supply and demand has not been clearly explored, although based on anecdotal evidence, there seems to be a clear upward trend in supply, especially of timber from the Amazon region, from October to December.

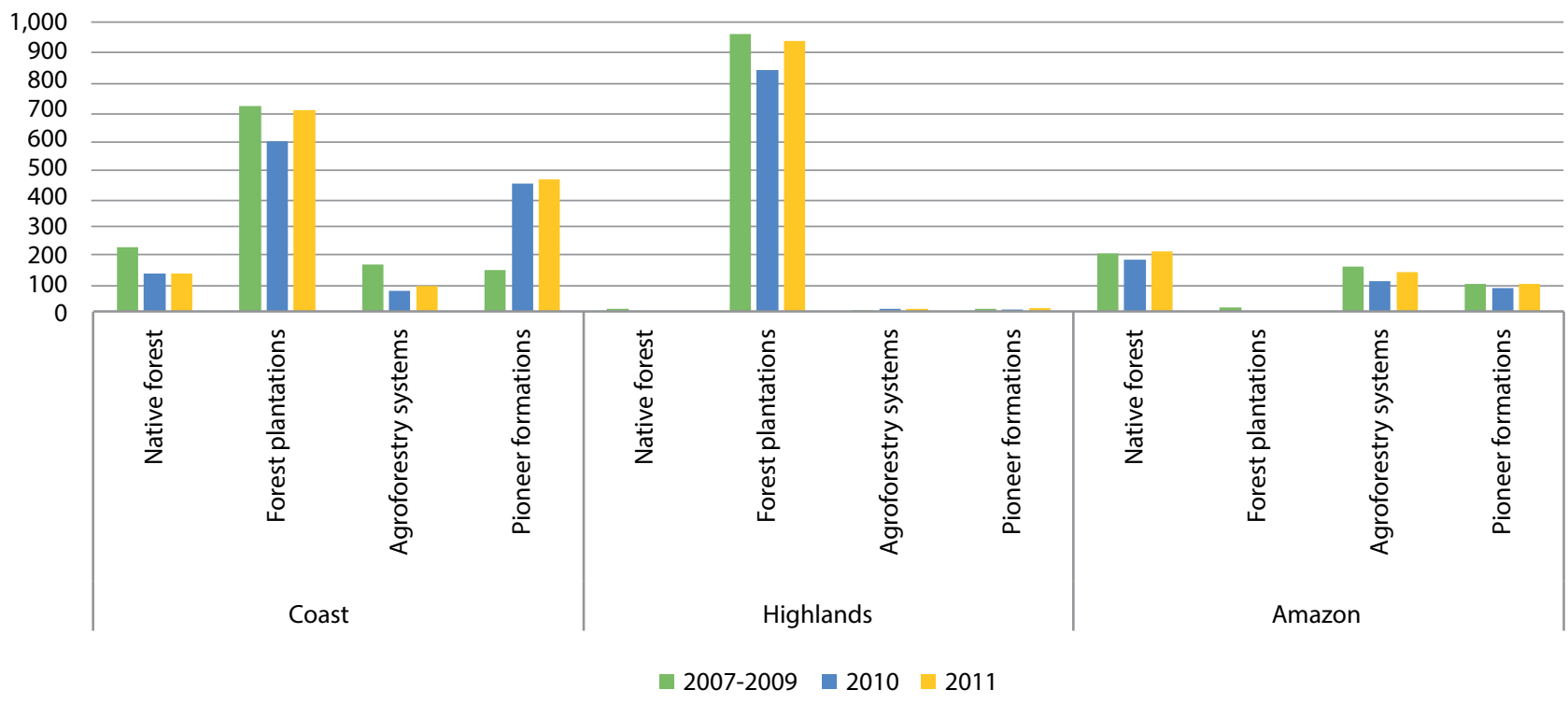

Figure 1. Timber harvesting by forest formation between 2007 and $2011\left(\mathrm{~m}^{3}\right)$. Personal compilation based on the Ministry of Environment of Ecuador (2011), SAF 2010 and 2011. 


\subsection{Forest control system in Ecuador}

Forest governance in Ecuador has primarily relied on forest control, especially until 2008 when the incentive program labeled Forest Partner (Socio Bosque) was started, and in 2011 when the Forestry Advisory system began. Before, between 2000 and 2006, the governance model was characterized by fostering outsourcing and decentralization of monitoring capacities in the Ministry of Environment to private third parties or local governments (Ministerio del Ambiente del Ecuador, 2006; Navarro, et al., 2009). In 2007 it was acknowledged that these strategies had resulted in weak institutions, and that they had failed to address the existing problems for forest management and control ${ }^{5}$, so MAE took over these duties again (SENPLADES, 2009). During this period, an intense participative process of forest policy making and regulation was developed.

In 2001, MAE coordinated the process with different groups of the private sector and the civil society to develop an independent forest control system. In this framework and due to the political/institutional instability in Ecuador resulting from lack of staff, limited financial resources and corruption, the Outsourced National Forest Control System (SNTCF for its acronym in Spanish) was promoted, through which the responsibilities of monitoring and public administration of operations to thirds parties were delegated (FAO, 2006; Navarro, et al., 2009).

This system was based on three components. The first was the establishment of a control body called Green Surveillance (Vigilancia Verde), with participation of the Government and the civil society, to monitor timber trade flows from production areas to the main markets. The second was the creation of a system of forest control by independent forestry advisors, called Forestry Advisory (Regencia Forestal), which is in charge of monitoring the legality of timber harvesting, and

5 SENPLADES 2010 report states that the main problems were: 1 . Absence of land management oriented towards sustainable development and management of forests; 2. Long and expensive procedures to legalize timber harvesting and transport; 3. High costs of legal forest use for smallholders and communities; 4 . Lack of a national system of forest control that effectively regulates the areas destined for permanent forest use and areas with a potential for forest plantations; 5. Lack of a forest register; 6 . Absence of a system of inspection of control processes. through which transparency in technical service provision and compliance with forest regulations in harvesting operations was guaranteed. The third was the handover of the administrative and inspection services to a private company. This was strongly questioned, leading to the failure of the initiative. In 2002, MAE entrusted SGS with the supervision of the forest control system. Nevertheless, in 2003 the Supreme Court of Ecuador declared that the new outsourced forest control system was inconsistent with the country's constitutional law. In 2004 the MAE and SGS agreement was cancelled (Navarro, et al., 2009).

A process of analysis and consultations started in 2006 to promote a new control system that resulted in the creation of the Decentralized National Forest Control System (SNDCF for tis acronym in Spanish), where the central Government, through MAE, assumed a governing role for setting forest control policies and running SNDCF at a national level. In turn, the provincial governments took over the responsibilities of approving the logging and harvesting plans and programs and issuing licenses, transport permits and in situ checking timber harvesting implementation. MAE was in charge of forest administration in regional districts, technical offices and all decentralized jurisdictions (Ibarra et al. 2007). This process made little progress as a result of: 1) minimum capacities of local governments to implement forest administration and control and 2) inability of the central government to monitor decentralized responsibilities (Ministerio del Ambiente del Ecuador, 2006; Ibarra, et al., 2008; Mejia, 2010).

With the change of government in 2006, the discussion was centered on deforestation and insufficient control by the State of the forest administration system and forest management. In the same year, the 2007-2010 National Development Plan (El Plan Nacional de Desarrollo 2007-2010) was formulated, which acknowledged several issues affecting forest governance including the weakness of institutions and political will, the problems of land management oriented towards promotion and sustainable management of forests, bothersome and expensive procedures for legalizing harvesting and timber transport, lack of a national forest control system that identifies and regulates the areas destined to permanent forest use and those with potential for forest plantations, as well as the lack of forest cadastre and the 
absence of a verification system. The recognition of these factors led to the reformulation of the forest governance approach based on five main areas: 1) incentive system, 2) forest information system, 3) forest administration and control system, 4) forest management, and 5) research, training and dissemination. According to Romero, $M$. (2013), the government of Ecuador has invested significant resources to guarantee the protection and preservation of over one million hectares by 2013 .

\subsection{Regulation and implementation costs}

The forestry regulations are those that directly define the rules for native timber harvesting. The main regulations include ${ }^{6}$ :

- Regulation of the Forestry Advisory system (Ministry Agreement \# 38, 2 August 2004). Failure of forestry advisors to comply with the roles and obligations established in the forestry regulations is analyzed on a case-by-case basis. The powers conferred to forestry advisors may be withdrawn temporarily or definitely.

- Administrative procedures to authorize timber logging and harvesting and standards for sustainable forest management for timber harvesting in the rain forests (Ministry Agreement \# 39, 31 March 2003)

- Transport permits for forest species (Ministry Agreement \# 9, 2 July 2001).

Under this legal framework, Ecuador seeks to guarantee the sustainable management of forest resources in the long term (For further details on the laws, see Annex 1).

Obtaining a permit for forest harvesting brings about some fixed costs, mainly stumpage paymentUSD 3 per harvested $\mathrm{m}^{3}$ - and additional transaction costs that tend to vary. Costs associated with the granting of permits to executors depend on the type of mechanism used for harvesting, the type of forest formation and the volume harvested, with specific programs for each case. However, it is worth noting that, according to FAO (2012), the costs associated with application of regulations to legalize timber harvesting constitutes an important institutional barrier, particularly for smallholders

6 See Annex I for a more detailed description of the regulation. who have limited resources and thus resort to third parties (intermediaries) to obtain liquidity in order to follow the legal procedures.

The costs to be covered by smallholders and intermediaries may be direct or indirect. Direct costs refer to the formal payments to MAE and other state agencies such as the Internal Revenue Service (SRI), public notaries and municipalities, which constitute part of the specified requirements for processing the timber harvesting permits. In turn, indirect costs involve the transaction costs that have to be covered in order to obtain the harvesting permits, including transport and wage payment to smallholders ${ }^{7}$. Both costs vary and depend especially on the volume of cubic meters that will be harvested, the size of the property and the distance to the city. Figure 2 shows the costs that would be incurred to approve logging programs on smallholdings.

Legalization of a harvesting program needs to be done by a third party forester or forestry advisors who collects information about the species on the field and applies the rules and standards that apply to logging and selection of suitable trees, and provides that information to the program executors. This procedure is one of the main requirements to obtain the timber harvesting permit (Tandazo and Gatter 2004). MAE grants users the logging permit for a year accompanied by the respective timber transport permits, as well as monitors the compliance of the forestry regulations, and imposes the sanctions (Figure 3). Timber legality is monitored through several check points in the main roads.

\subsection{The role of SAF in current forest control}

In the 2007-2008 period, the Ministry of Environment started a new strategy within the Forest Control System (SCF for its acronym in Spanish). According to MAE (2011), SCF actions are based on SAF implementation which is the cornerstone of the forest monitoring and control system. It generates information that enables forest control and contributes to verification

7 It is customary to make daily payments to smallholders for administrative procedures in the city. This payment is made by the intermediary and ranges between USD 10 and 15 . 


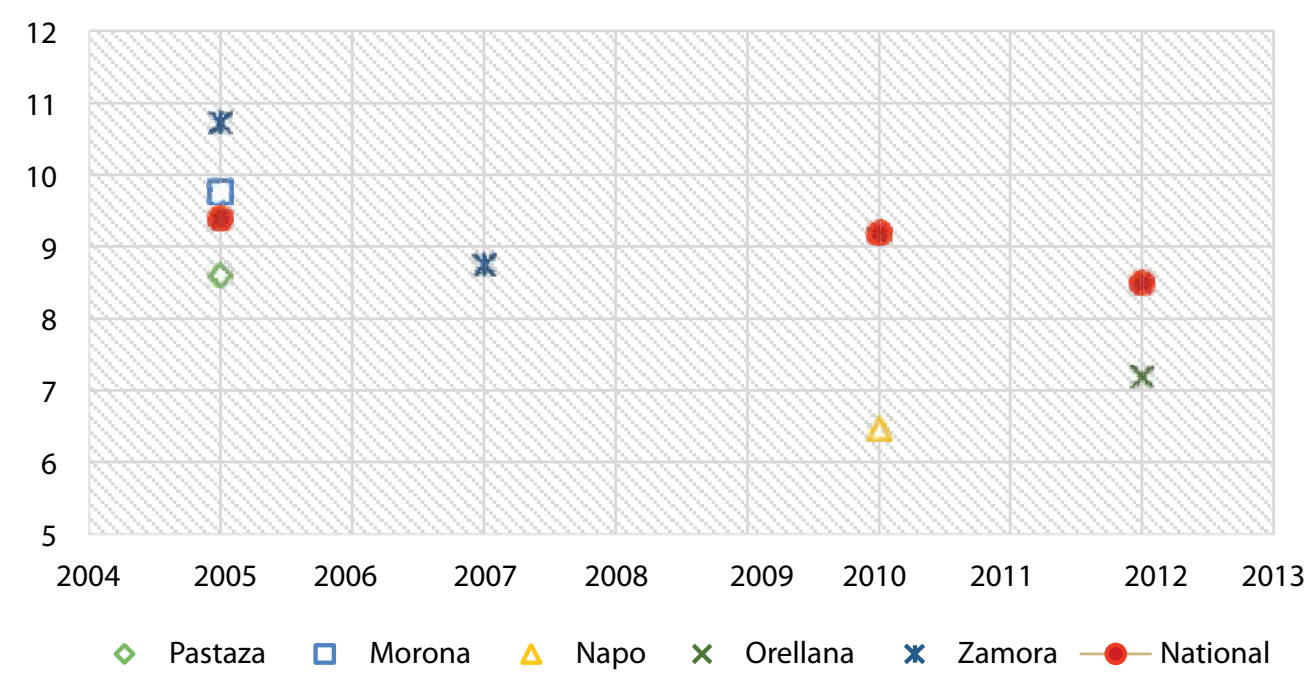

Figure 2. Amazon: Legalization costs in the period 2005-2012 (in USD $/ \mathrm{m}^{3}$ ). Personal compilation based on case studies in the provinces of the Ecuadorian Amazon (Hetsch, 2004; Díaz y Gatter, 2004; Merino, 2010; FAO, 2012; Schlotzhauer, 2012) and personal data from the field work of the authors.

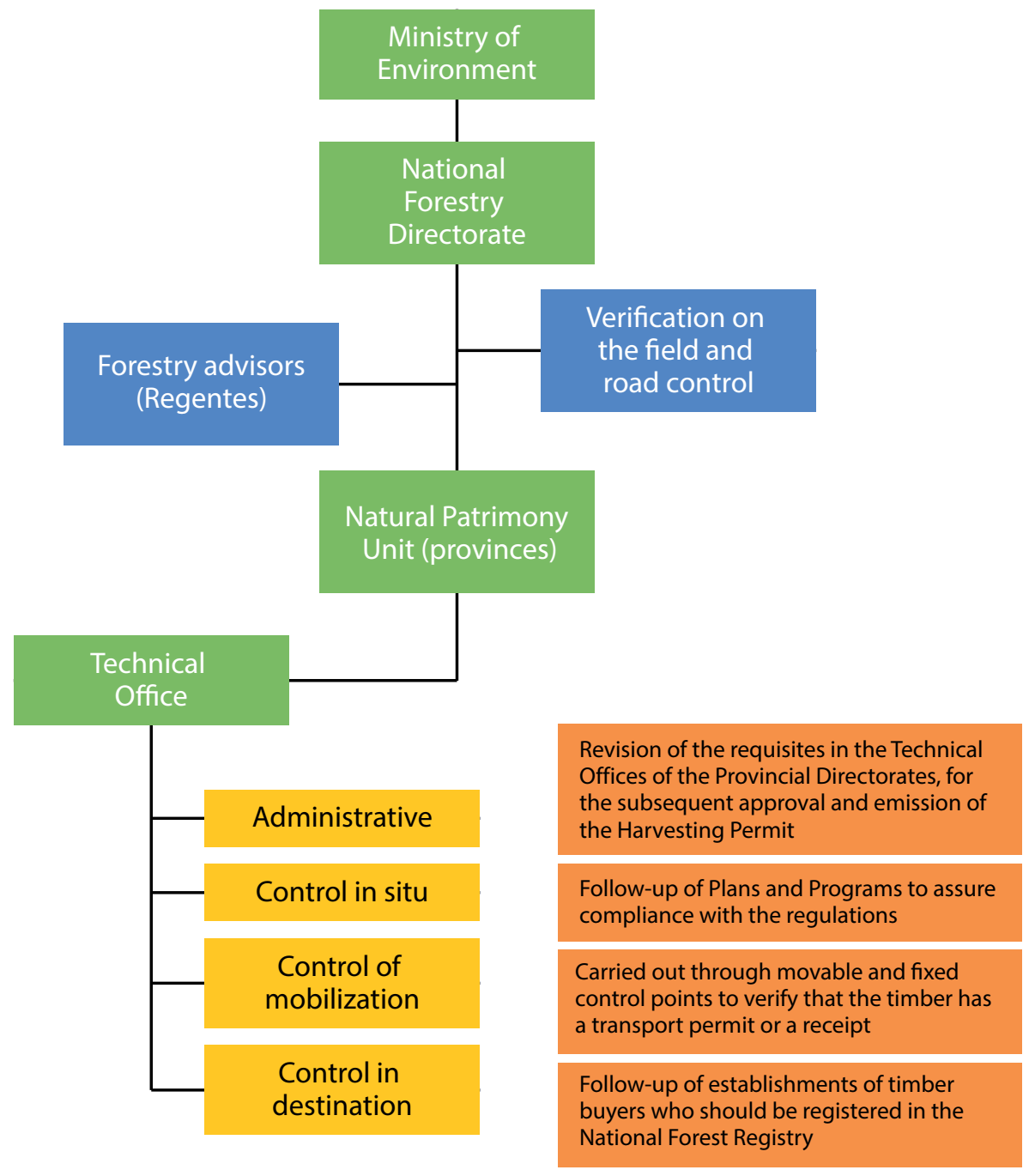

Figure 3. Forest control system, based on information gathered in the web page of the Ministry of Environment of Ecuador. http://www.ambiente.gob.ec/sistema-nacional-de-control-forestal/ 
of legal timber supply from timber harvesting to mobilization to the end market (Figure 3). Although this system has clearly accelerated the process of issuance of permits for timber transport, it has not necessarily improved control of timber at the origin. According to anecdotal evidence, there is still an important informal market of transport permits, the use of these permits for more than one circuit for which the permit was issued, and lenient supervision in some control points, which facilitates evasion.

SAF relies on a series of legal and institutional standards that provides the framework for implementing the forestry regulations, by both MAE central and regional offices. The goals that the MAE expects to reach with SAF are as follows: 1) to administer and provide information on forest resources at a national level, 2) to monitor the different legal procedures along the timber value chain, i.e. from timber harvesting to marketing of processed products in the national and international market, and 3) to learn about the characteristics and conditions of timber species and their use in order to improve the performance of the Forest Harvesting Programs.

The first SAF stage (now known as SAF I) was started in 2008, and by mid-2009 the second phase (known as SAF II) was started to solve the gaps found in the previous procedures of the system. The new SAF version has been operating since 2012 and was especially designed to improve the articulation between the register of forest harvesting plans, timber transport permits and the process of legal timber supply verification at the processing centers. Table 5 compares SAF I and II basic features.

The following have been the main improvements introduced in SAF II:

- The most important change has been that SAF II enables users (owner, forestry advisors and/or executor) to register the program to be executed on line, which is expected to significantly reduce waiting periods for approval.

- The control module was adjusted to allow MAE technicians at the fixed control points to access the system and verify the numbering of the species under scrutiny; in addition, the joint signatures and the executors' signatures can be seen, optimizing the relation of the assessed species with their respective licenses.

- The forestry advisory module was improved. As a result, the change procedure can be made immediately, optimizing the processing time.

- Together with the Ecuadorian Customs Corporation (Corporación Aduanera Ecuatoriana), the necessary mechanisms to access the institution's database were established to improve the control of exports of both timber and non-timber forest products.

Table 5. Improvements from SAF I to SAF II at user level

\begin{tabular}{|c|c|}
\hline SAF I & SAF II \\
\hline $\begin{array}{l}\text { Certification of the actors engaged in harvesting } \\
\text { with documents }\end{array}$ & $\begin{array}{l}\text { Documents are uploaded for the certification and } \\
\text { registration }\end{array}$ \\
\hline $\begin{array}{l}\text { Two points of reference are entered to locate the plot } \\
\text { where harvesting will take place }\end{array}$ & $\begin{array}{l}\text { In order to spatially register the area to be harvested, at } \\
\text { least four geographical points are needed }\end{array}$ \\
\hline The satellite image cannot be viewed & The satellite image can be viewed \\
\hline $\begin{array}{l}\text { All documents are required whenever a procedure is } \\
\text { carried out }\end{array}$ & $\begin{array}{l}\text { Documents are stored, so that users do not need to carry } \\
\text { out the entire procedure again }\end{array}$ \\
\hline Transport permit with a RUC and without verification & Transport with a RUC registered in SAF and a certificate \\
\hline Depots do not need to be registered & $\begin{array}{l}\text { Permit for transport and storage is needed. Depot must } \\
\text { also be registered (only for pigüe) }\end{array}$ \\
\hline \multirow[t]{2}{*}{ Inspection } & Full inspection only in Napo, Orellana \\
\hline & $\begin{array}{l}\text { Internet is used in control operations, so the chain of } \\
\text { custody can be revised }\end{array}$ \\
\hline \multirow[t]{2}{*}{ The register of permits is displayed normally } & The register is not displayed \\
\hline & Export and monitoring of export permits \\
\hline
\end{tabular}

Source: Own elaboration based on data from interviews to staff of the Ministry of Environment of Ecuador. 
Table 6. Payments for the legalization of standing trees or foothill forests (plantations not included)

\begin{tabular}{|c|c|c|c|c|c|c|}
\hline & \multirow{2}{*}{ Harvesting programs } & \multicolumn{5}{|c|}{ In USD } \\
\hline & & 2007 & 2008 & 2009 & 2010 & Average USD/year \\
\hline PAFSI & Simplified Forest Harvesting Plan & 499.5 & 750 & 558 & 577 & 596.1 \\
\hline PAFSU & Sustainable Forest Harvesting Plan & 573 & 565.5 & 524.4 & 488.2 & 537.8 \\
\hline PCAR & Logging Program for Relict Trees & 381 & 494.7 & 510.3 & 643.5 & 507.4 \\
\hline PCZCL & $\begin{array}{l}\text { Logging Program for Legal } \\
\text { Conversion Areas }\end{array}$ & 28.5 & 39 & 107.1 & 125.8 & 75.1 \\
\hline \multicolumn{2}{|c|}{ Total amount per authorized timber } & 1482 & 1849.2 & 1699.8 & 1834.6 & 1716.4 \\
\hline
\end{tabular}

Source: FAO (2012).

- Through Google Earth@ platform, the possibility to verify the GPS points of the plot to be registered was provided. If MAE's technician considers that the forest cover is smaller than that delimited in the standard, the permit is denied or canceled.

- The Single Tax Payer Registry regulates timber final destination for the first time, which is expected to complete the circle of forest product marketing and traceability from the forest to the industry.

- A web site for accountable public procurement is expected (undefined) to be developed ${ }^{8}$.

- SAF II is part of the Single System of Environmental Information (Sistema Único de Información Ambiental, SUIA), which is intended to articulate MAE's database within the National Information System (Sistema de Información Nacional) led by SENPLADES, in a government effort to improve land planning.

In order to cover SAF costs, MAE has a budget allocated by the central Government, apart from users' direct contributions. The budget is coordinated through the Annual Operational Plans (POA for its acronym in Spanish) ${ }^{9}$. According to FAO (2012), payment for timber forest usestanding timber ${ }^{10}$ - has been 1.7 million/year on average. These payments are part of the Forest

8 The purpose of the National Services for Public Acquisitions is to make national production more transparent and dynamic through public procurement by the Ecuadorian State. http://capacitacion.compraspublicas.gov.ec

9 POA 2012. http://www.ambiente.gob.ec/wp-content/ uploads/downloads/2012/07/Plan-estrategico-MAE-2012.pdf 10 Article 29, Section g, Forestry Law
Management System (SAF), since it is another requirement in the legalization process for forest operations. Table 6 shows incomes from legal timber. Income from native forests (PAFSI and PAFSU) amounts to around $66 \%$ of total income.

Apart from the economic resources, MAE has 1671 officials at the national level. The National Forestry Directorate (DNF for its acronym in Spanish) has a total of 136 officials, accounting for $8 \%$ of total MAE staff. According to the Ministry of Environment of Ecuador (2011), this Directorate has sufficient technical and administrative capacity to respond to and support the needs and requests of the forestry sector; however, for Thiel and Trelles (2008), one of the limitations to improve forest management is the lack of staff, especially in the Amazon. In accordance with MAE 2012 records, new officials have been incorporated to technical offices; nevertheless, the number of steps to follow has also increased. In perspective, according to SAF 2011 databases, around 3050 users were assisted this year, with approximately 140,000 transport permits across the nine fixed points.

\subsection{Implications of control on small- scale timber harvesting}

As indicated above, the domestic market is mainly supplied with timber from plantations, but it is suggested that timber from the Amazon is increasing (Vásquez 2011). Some of the sawn timber consumed by the industry of secondary processing of furniture, moldings, floors, doors and windows comes from chainsaw milling from 
PAFSIs and informal operations in native forests. For the same reason, the standards and forest control system have relevant implications on smallscale uses, since they enable both technical and economic feasibility.

According to Thiel and Trelles (2008) Ecuadorian forest regulations have been adapted to existing approaches for sustainable forest use according to the forest user type, type of forest exploitation and the type of forest (for instance, native or planted forest, remaining trees, agroforestry systems). In native forests, considering the general criteria for forest management, technical parameters for timber harvesting have been designed and issued, requiring a land use management plan and a PAFSU when harvesting includes use of hauling machinery. For harvesting without mechanized hauling, a Simplified Forest Harvesting Program (PAFSI for its acronym in Spanish) is required, which is accessible in small areas and provides fast access to logging authorization granted by the forest authority for small forest producers. One of the most important characteristics of this type of program is that it allows chainsaw milling.

In spite of these adjustments, there is still informality in small-scale harvesting, which is probably associated with the institutional barriers and transaction costs previously mentioned, as is also suggested by FAO (2012). The informality in timber harvesting and transport is recognized by several authors (Añazco, et al., 2010; Ministerio del Ambiente del Ecuador, 2011; Vásquez, 2011). However, apart from studies of specific cases, there is little solid evidence of the magnitude of informal timber harvesting. Some research suggests that there are some rather well-structured networks for timber harvesting and intermediation between different market actors that operate informally (Palacios and Malessa, 2010). Others have made a greater effort to document the distribution of the benefits of informal harvesting for smallholders (Hetsch, 2004; Gatter and Romero, 2005; Kautz, 2005). 


\title{
Actors, intermediation and forest control in the Amazon
}

\author{
Elena Mejía, Pablo Pacheco, Johanna Morocho, and \\ Santiago Alarcón
}

\begin{abstract}
The discussion on state control over the forest resources started in 1990, when policies on protected areas and wildlife conservation were adopted (Vinueza, 2012). At the end of the decade, together with the process of state modernization, the system of forest control outsourcing was adopted, through which key monitoring and control activities were transferred to third parties, as stated in chapter 2 . The system was in force until 2006, when it was replaced by the National Forest Control System (Sistema Nacional de Control Forestal) (FAO, 2006; MAE, 2006; Navarro et al., 2009; Mejía, 2010). This proposal was focused on the fact that the national Government should be in charge of the implementation of the institutional mechanisms to ensure compliance with forest management standards, and thus legal timber supply through the application of SAF.
\end{abstract}

There is a discussion about the fact that standards and regulations for timber harvesting become economic and institutional barriers that tend to exclude smallholders and local forest users from access to forest resources and timber markets (Chommitz, 2007; Pokorny and Johnson, 2008; Brown, et al., 2009; Pacheco, et al., 2009).

Nonetheless, there is still little detailed empirical evidence on the impact that forest management standards and regulations have on the different agents that undertake timber harvesting, especially small producers and indigenous communities. It is often assumed that the actors that fail to comply with the existing forest standards do not necessarily stop harvesting timber from their forests but rather tend to carry out timber extraction informally, which is often considered illegal.

This chapter explores the factors that lead local forest users to choose informal mechanisms when harvesting and marketing their timber. Thus, 123 semi-structured interviews were conducted with key informants with different roles in the timber harvesting and marketing chain. These interviews were carried out between May and September 2012. The main purpose was to understand to what extent existing timber harvesting standards, along with forest control, affect the way in which different actors (including smallholders, indigenous peoples, intermediary chainsaw operators) interact with one another during the different operations from harvesting to marketing, as well as the strategies that are put in place in order to evade main institutional and legal barriers.

Key informants were selected according to opportunistic sampling that used the information given by other informants. This study was conducted in parallel with other cost-benefit studies on harvesting (chapter 6), so the selection of the communities where the interviews to key actors were held is the same as that in the study based on household surveys. Thus, the same sites were intended to be included to have a sample of colonists, Kichwa and Shuar smallholdings. The number of informants interviewed is found in Table 7.

\subsection{Characteristics of intermediation actors}

\subsubsection{Smallholders}

Gatter and Romero (2005) estimate that colonist smallholders in the Amazon have on average access to 50 hectares under individual tenure, while indigenous smallholders control 75 hectares on average, under either individual or community tenure. In the case of Napo, these averages are relatively lower, the smallholders having access to from one to 40 hectares on average ${ }^{11}$.

11 Taken from a survey to Kichwa families. RUNA (2012). 
Table 7. Key informants interviewed

\begin{tabular}{lcl}
\hline Informants & No. of informants & Comments \\
\hline Smallholders & 6 & Current and former presidents of local communities \\
Depot owners & 40 & Timber buyers and sellers \\
Intermediaries & 30 & Different types of intermediation \\
Executors & 6 & Linked to the intermediary \\
Forestry advisors and & 9 & Working in the region, but not living there \\
forestry technicians & 10 & Independent and wage earners \\
Chainsaw operators & 19 & Local and external \\
Transporters & 3 & Independent and wage earners \\
Haulers or raft drivers & 123 & \\
Total &
\end{tabular}

Source: Own elaboration.

Indigenous people: they have a community reserve, usually with collective title. The Community Assembly is entitled to allocate new land plots in the community reserve to married members that start a new family. This allocation process is valid for men but not for women, since they acquire land when they get married (FAO, 1997). Women landowners are generally widows ${ }^{12}$. The indigenous people interviewed are considered smallholders regardless of the size of their property.

Colonists: colonists (mestizo immigrants) have individual ownership titles for their lands or some form of recognition of their individual tenure rights. Colonists are considered smallholders when they access less than 100 hectares. Colonists mainly use the land for cocoa and coffee growing, as well as cattle ranching.

\subsubsection{Intermediaries}

Timber harvesting and marketing are influenced by the speed of market demand in terms of volumes, quality and species, thus the actor that does the intermediation between smallholders and the end market, is known as "intermediary". The intermediaries interviewed in Napo and Orellana mostly come from the Highlands (61\%). A total of $75 \%$ had previously a different activity and were interested in timber only after migrating to the Amazon; the remaining 25\% had always worked on timber production because it was a family

12 In the interviews with community presidents, they said that the new generations are granting the same rights to their single daughters, but not to their married daughters. activity. Of the overall number of intermediaries interviewed, $66 \%$ are timber intermediaries (i.e. this was their main occupation), and 34\% stated that their main activities are agriculture and cattle ranching. The secondary activity of intermediaries is usually composed of $74 \%$ agriculture and cattle ranching and $26 \%$ trade. The total number of intermediaries in the areas where this study was undertaken is unknown. These intermediaries do not belong to any association, so it was not possible to draw a sample, thus opportunistic sampling was used.

These intermediaries play different roles and their tasks are established in accordance with the volume of capital available to them. A typology of intermediaries is presented in Table 8. It is worth mentioning that, depending on the conditions, the intermediaries can move from one type of intermediation to another depending on the opportunities.

\subsubsection{Executors}

The executor is the person legally responsible for timber harvesting on a plot. Smallholders themselves sometimes play this role. However, very often these actors do not necessarily participate in the extraction or intermediation operation, but rather they 'lend' their legal status so that the intermediary can implement a management plan, especially when it has been legally approved. Executors are the people who are registered in SAF under their name and RUC number, which authorizes them to sign the necessary documents before the MAE authority, assuming responsibility for compliance with the law 
Table 8. Typology of intermediaries

\begin{tabular}{ll}
\hline Type of intermediary & Actions \\
\hline Timber intermediary & Negotiates with the final buyer \\
(Sometimes executor) & Negotiates with the smallholder (buys standing timber, logs, hectares) \\
& Assumes authorization costs \\
& Assumes operation costs \\
& Assumes transport costs \\
& Sells to final destination \\
\hline Transportation intermediary & Negotiates with the final buyer \\
& Negotiates with the smallholder or sawyer-intermediary \\
& Assumes transport costs \\
& Sells to final destination \\
\hline Broker intermediary & Negotiates with the timber intermediary \\
(Forestry advisors and & Negotiates with the smallholder \\
forestry technicians) & Does not sell timber \\
\hline sawyer-intermediary & Negotiates with the final buyer \\
(Small operations) & Negotiates with the smallholder (the sale of standing trees) \\
& Assumes the costs derived from the operation \\
\hline
\end{tabular}

Source: Own elaboration based on interviews conducted between May and September 2012.

Table 9. Type of executor

\begin{tabular}{ll}
\hline Type of executor & Actions \\
\hline Logger implementer & It is the intermediary himself who carries out the harvesting \\
\hline $\begin{array}{l}\text { Smallholder } \\
\text { executor }\end{array}$ & $\begin{array}{l}\text { The smallholder does the harvesting } \\
\text { The smallholder authorizes the intermediary to harvest on his behalf }\end{array}$ \\
\hline Hired executor & $\begin{array}{l}\text { Hired by the intermediary to register his name before the National Forestry Register } \\
\text { He is responsible for signing the application for registration and other related formalities } \\
\text { Not related to the harvesting activities }\end{array}$ \\
\hline
\end{tabular}

Source: Own elaboration based on interviews conducted between May and September 2012.

during harvesting and transport. These actors are not present during informal harvesting. A typology of executors is established and presented in Table 9.

\subsubsection{Forestry advisors (regentes) and technicians}

Forestry advisors are part of the outsourced forest control system implemented by MAE; currently, they are autonomous professionals who are paid for the volume of timber moved under the management programs approved by them. In the case of harvesting and logging programs, advisors count the trees per species or perform a forest inventory of the plot ensuring that legal standards for harvesting are met. The forestry advisors interviewed come from the Highlands and the Coast, out of whom,
$50 \%$ stated that being a forestry advisors is their main activity and the remaining $50 \%$ carries out complementary private and public activities. All of them said that they work more with intermediaries and that the cases in which the smallholders prepare a program on their own are exceptional. In 2011, the advisors surveyed stated that they had more Logging Programs than Harvesting Programs, which indicates that timber mostly comes from properties with agroforestry systems.

The demand for forestry advisory work is high. Many times, forestry advisors do not live in the same region, so they hire the services of third parties, called forestry technicians, who sometimes create work teams to meet the demand for logging 
and harvesting programs. Forestry technicians prepare management plans and are in charge of supervising all the necessary steps. In many cases, forestry technicians are also like brokersintermediaries (Table 10). In practice, forestry technicians are informants of species and prices between intermediaries and smallholders, receiving a "tip" for the information; they are often also involved in the development of a formal program.

\subsubsection{Chainsaw operators}

Sawyer or chainsaw operators are mostly wage earners who work in timber extraction; nonetheless, they also become intermediaries when they organize generally small and often informal operations. Chainsaw operators in Orellana are organized in the Association of Professional Sawyers (ASOPEM for its acronym in Spanish); however, the professionalization of the activity is not clearly recognized.

They come mostly from the provinces of Orellana and Napo, and from the Coast, $60 \%$ and $40 \%$ respectively. None of the interviewees has finished secondary school, which is one of the most important reasons why they work on forestry or agricultural activities and not as an employee in an oil company. $60 \%$ of them have been working in this activity for 4 to 9 years, and $40 \%$ for over 10 years. Chainsaw operators simultaneously work as wage workers on a daily wage basis and in several other activities to compensate for the months in which they do not work in harvesting activities. Chainsaw operators have one chainsaw on average. $90 \%$ bought the chainsaw with the aid of the intermediary they work with, from stores in the cities of Tena and Coca.

\subsubsection{Haulers (rafters) and assistants in forest harvesting}

Haulers, also known as rafters, are the actors in charge of opening small paths in the forest to take the sawn timber from the logged areas to the road on donkeys. The work of haulers is done in two main ways: 1) They can be directly hired by the timber intermediary to manage the donkey herd owned by the intermediary, or 2) they can offer services and rent their animals for a certain amount of days according to the needs of the operation. Assistants are in charge of performing minor tasks for the rest of the actors in the production chain, such as cooking, driving vehicles to move operation materials and staff, helping in the care of animals and riding motorcycles to check different operations, among others.

\subsubsection{Depots and sawmills}

The owners of these facilities were interviewed in Tena, Coca, Huaquillas, and Ambato. 100\% of them exclusively purchase and sell processed timber and, to a lesser extent, roundwood. All interviewees came from other provinces. A total of $70 \%$ of them started working in this activity as intermediaries until they had enough capital to purchase processing machinery; the other $30 \%$ inherited the business from their parents. All interviewees said they had not had any problems with the forest authority since they do not often conduct harvesting programs; their business consists in purchasing, processing and selling the timber.

Table 10. Type of intermediaries and payments made to the smallholder

\begin{tabular}{lll}
\hline Intermediary & Operation & Payment \\
\hline Timber intermediary & $\begin{array}{l}\text { Intermediary saws and transports } \\
\text { Smallholder saws the timber }\end{array}$ & $\begin{array}{l}\text { Payment in advance } \\
\text { Payment at the end of operation }\end{array}$ \\
\hline Transportation intermediary & $\begin{array}{l}\text { Smallholder saws the timber and hauls it } \\
\text { to the road side. }\end{array}$ & $\begin{array}{l}\text { Payment of 50\% on purchase } \\
\text { Payment of 50\% 15 days later }\end{array}$ \\
\hline Sawyer-intermediary & Intermediary saws and transports & $\begin{array}{l}\text { Price of standing timber is } \\
\text { USD 20-30 per tree }\end{array}$ \\
\hline Broker intermediary & $\begin{array}{l}\text { Intermediary looks for a timber dealer, } \\
\text { transporter or chainsaw operators }\end{array}$ & He does not pay the smallholder \\
\hline
\end{tabular}

Source: Own elaboration based on interviews conducted between May and August 2012. 


\subsection{Intermediary relations}

Timber harvesting and marketing is strongly influenced by market demand and the way in which smallholders are connected with these markets. These interactions are eased by means of the intermediation work of the so-called "intermediaries", who play different roles, usually related to their financial and logistic capacities. Depending on the circumstances, intermediaries can adopt different strategies, as indicated in Table 8.

\subsubsection{Intermediaries and final buyers}

The first link in intermediation is established between the final buyer (generally external), who is usually the owner of a depot or sawmill, and the intermediary when they agree on an order. The order is the request for timber made by the final buyer to the intermediary. It is normally an informal agreement between both parties that guarantees the delivery of the timber within a certain period of time with established features of size, quality of sawmilling and species. Final payment to the intermediary once the timber is received by the buyer takes between 15 and 20 days. In this period the costs that need to be paid by the intermediary for new forest harvesting operations are covered with income derived from activities such as cattle ranching or other income from timber sale. This waiting period by the intermediary also tends to affect timber prices and terms of payment to the smallholder and the staff working on the harvesting. There are intermediaries who own the depots and sawmills and directly harvest and then sell processed timber locally or externally to larger traders in cities like Quito, Guayaquil, Ambato, and Huaquillas ${ }^{13}$.

Both the purchase order and the payment constitute an informal contract between buyers and intermediaries, except when there is a legal invoice involved. In accordance with the information collected, only one of two verbal exchanges results in a purchase-and-sale agreement. Contracts between the final buyer and the timber intermediary are mostly made through telephone calls or via internet. Payments are made via bank

13 Timber that is processed and then transported with purchase invoices is not clearly registered. transfer, in two or three installments for as long as the forest operation lasts. The factors that prevent a purchase-and-sale transaction from taking place are related to intermediaries' inability to meet timber delivery deadlines, which makes buyers try to find other intermediaries to supply their stock.

The intermediaries who own depots or sawmills in the main towns of Tena and Coca also supply for the demand of oil companies and local governments, who buy timber especially destined to construction. The timber purchase generates an invoice through which the volume bought can be known. However, there is no certainty yet as to whether the origin of this timber is legal or illegal ${ }^{14}$.

\subsubsection{Smallholders and intermediaries}

Timber marketing is carried out by two different types of intermediaries who are referred to here as "timber intermediary" and "transportation intermediary", which are described in Table 8. The transaction between smallholders and intermediaries can be formal or informal, which normally depends on the volumes of marketed timber, the species and the destination market. The final result of the negotiation is setting the price and form of payment, as stated in Table 10. Contact with smallholders, according to the intermediaries interviewed, is established on the basis of family relations, through co-workers or forestry advisors; in some cases, smallholders themselves find intermediaries.

Even though intermediaries work with indigenous and colonist smallholders, according to the interviewees, they prefer to work with colonists because of the guarantee of compliance with the agreements; however, they work more with indigenous people because they have larger forest areas. In both cases, after requesting permits for harvesting within the communities or individual plots, intermediaries negotiate the "purchase order" verbally. This negotiation includes especially agreeing on some specific aspects regarding: 1) volumes per species to be extracted, 2) type of product, 3) quality, 4) time of delivery, and 5)

14 The Government's purchases are made through the public procurement web site. However, only one purchase made by a local Government was registered for 2011 http:// www.compraspublicas.gob.ec/compraspublicas/ 
price and form of payment. These purchase orders are normally the result of previous agreements made between the intermediary and the final buyer, as previously stated.

\subsubsection{Forestry advisors, intermediaries and smallholders}

A total of $60 \%$ of the intermediaries interviewed negotiate the logging and harvesting programs directly with smallholders, while the other $40 \%$ prefer the forestry advisors or forestry technician to be in charge of the negotiation. In this case, forestry advisors or forestry technician are classified as "broker intermediaries". The community authorities interviewed stated that they prefer to have a previous negotiation with a broker intermediary to "explore" the prices that they will receive for the different species and products to be harvested.

The smallholders interviewed claimed that "the purchase order" is directly negotiated with the intermediary and that they do not harvest timber if they are not certain of the type of order. Smallholders said that they sometimes find intermediaries to offer them valuable species like chuncho (Cedrelinga catenaeformis) and colorado (Guarea $s p$ ); however, it is the intermediary who indicates the volume of the product that is needed to complete their purchase order with the final buyer, although these species have a secure market.
Very often the intermediary resorts to timber from several programs, or they buy timber from plots without a program. According to information gathered from the interviews, it is estimated that $65 \%$ of the illegal timber bought through intermediaries would be "laundered" through management plans from neighboring informal harvesting areas, which could be due to the fact that trees having mechanical and pathological damage do not often reach the $50 \%$ waste authorized by regulations.

The transportation intermediary usually negotiates the purchase order directly with the smallholder, and, in general, the timber obtained with no management plan is sold to local timber markets in Tena and Coca, while the timber obtained formally, or which is subsequently laundered, is destined for foreign markets. The difference between this type of intermediary and the timber-intermediaries is that transportationintermediaries are in charge of transport, not harvesting, and they purchase smaller volumes.

Figure 4 provides an overview of intermediary relations for timber between final buyers and the different types of intermediaries, and between these and smallholders (both indigenous and colonists).

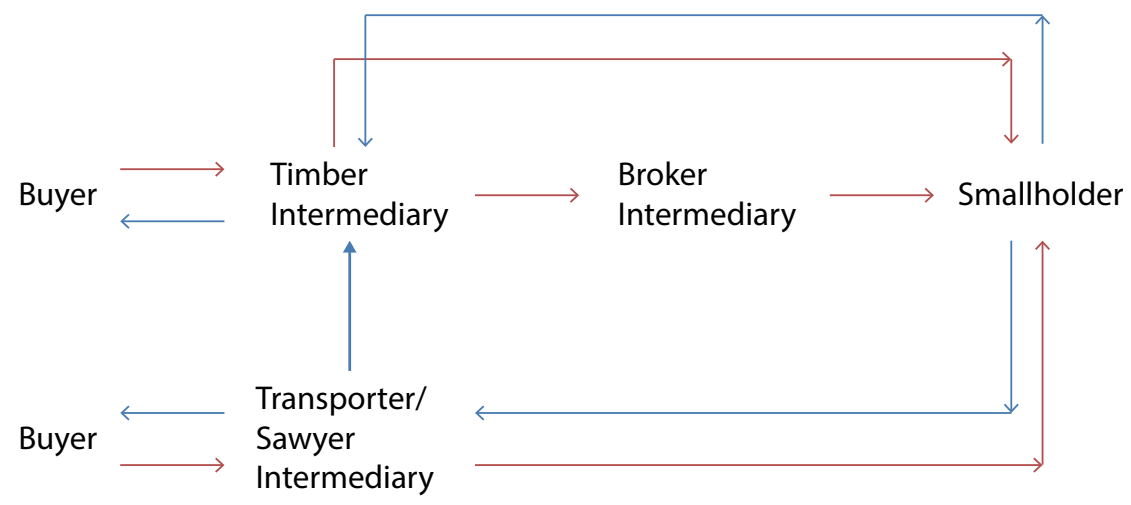

Figure 4. Intermediaries in timber trade, based on information obtained from interviews between May and September 2012. 


\subsection{Trust relations and conflicts with the authority}

As observed, confidence relations between the actors of harvesting and marketing are the pillars of market transactions. Intermediaries and forestry technicians, for instance, prefer to work with their own families. Conflicts with other actors, according to most respondents, are related to compliance with verbal agreements and timber mobilization. Nobody mentioned conflicts with the legalization process, but rather with MAE control processes, like in the case of field and road inspections (Table 11).

A total of $77 \%$ of the intermediaries interviewed trust forestry advisors, and 52\% trust MAE as well. An overall figure of $70 \%$ of Interviewees believe that control has improved legal and informal timber prices, as control has removed competition from the intermediaries who did not have enough capital to afford legalization costs. These actors consider that the most frequent conflicts are caused by the waiting time for approval of harvesting programs and confiscations by the fixed and mobile control points of MAE. As regards to trust in smallholders, the intermediaries admitted that, out of four plots chosen to be formally harvested through logging or harvesting programs, only two were actually logged, due to different reasons, especially the fact that verbal contracts are not completed by smallholders. For these reasons all the intermediaries interviewed believe that the timber business is very unstable and the future is uncertain.

The forestry advisors interviewed stated that the main problems they have had to face with MAE derive from poor program implementation, inappropriate use of transport permits and lack of program supervision. Although they believe that regulations do not acknowledge smallholders' situation, increased MAE control and efforts have noticeably improved intermediaries' legalization figures, such is the case that they prefer to prepare management plans rather than use informal means in timber harvesting and transport. As a result, this has improved forestry advisory activities.

In turn, chainsaw operators recognized that they are aware of the implications of informality; nevertheless, they notice that they are better paid when working with an intermediary who has an approved harvesting program, so they have a positive view on legalization. However, this is also associated with the fact that these formal operations tend to harvest timber with commercial value. Nobody has worked with smallholders who have developed a harvesting program on their own, but they have worked with these actors in informal logging sporadically.

There are timber transporters who are not transportation intermediaries-i.e. they are hired to mobilize products of logging but have not taken part in harvesting. These actors believe that MAE control is not adequate since they often have to mobilize timber loads, whose origin or species they do not know. Due to this fact, these actors face the risk of confiscation of the timber they transport causing daily losses and extra expenses. The current strategy of these actors is to pay the forestry advisors or forestry technicians approximately USD 15 per truck so that they revise the cargo and certify that the species match those on the list in the transport permits.

It is interesting to note that none of the depot or sawmill owners interviewed said that they had problems with MAE, but they assure that control has led to increases in timber prices.

Table 11. Conflict between actors in timber harvesting

\begin{tabular}{|c|c|c|c|c|c|}
\hline \multirow[b]{2}{*}{ Actors } & \multicolumn{5}{|c|}{ Conflicts } \\
\hline & $\begin{array}{l}\text { Control of } \\
\text { MAE }\end{array}$ & $\begin{array}{l}\text { Confiscations } \\
\text { in controls }\end{array}$ & Late payment & $\begin{array}{l}\text { Lack of } \\
\text { seriousness in } \\
\text { the agreement }\end{array}$ & $\begin{array}{l}\text { Lack of training } \\
\text { in the use of } \\
\text { technologies }\end{array}$ \\
\hline Smallholders & & & $x$ & & $\mathrm{X}$ \\
\hline Intermediaries & $x$ & $x$ & & $x$ & $x$ \\
\hline Transporters & $x$ & $x$ & & & \\
\hline Forestry advisors & $x$ & & $x$ & & \\
\hline
\end{tabular}

Source: Own elaboration based on interviews conducted between May and August 2012. 
"Control has led to an increase in certain timber species prices. It is small businesses or depots managing volumes of 1 to $5 \mathrm{~m}^{3} /$ month that promote greater marketing of timber of informal origin, giving rise to a reduction in formal timber prices in the local market." Owner of depot interviewed

Small establishments are located in periurban and rural areas and have not been registered, so it is difficult to know an approximate figure of timber marketing through these actors.

The interviewed smallholders and community presidents found no direct problems with MAE. This may be due to the fact that it is intermediaries and forestry advisors/forestry technicians who should carry out the appropriate administrative procedures and make the necessary payments for the approval of harvesting programs, while owners only give their consent and sign the paperwork. In addition, they stated that timber laundering (Box 1) is a practice that has never caused problems in their communities.

\subsection{Actors' strategies to evade the control system}

In the areas under study, evasion of the control system mainly occurs to avoid losses of timber already harvested formally or informally. According to interview results, the following are used as the main evasion strategies, in order of importance asked to respondents: 1) purchase of transport permits; 2) sale of timber in the capital cities of the provinces, 3) laundering through the use of approved logging and harvesting programs; 4) use of illegal payments to the police and forestry surveillance staff (known as coimas, i.e. bribes) at control points; 5) mobilization with invoices as support documents; and 6) approval of fictitious plans to generate transport permits. Some of these forms of evasion are used during harvesting and

\section{Box 1. Timber "laundering" process}

Timber laundering refers to the process of legalization of informal timber through a network of actors with sufficient capacity to adapt to the demand of timber products and who have the necessary flexibility to carry out these operations, mainly because they work with small timber volumes. There are two kinds of laundering. The first, "more formal", is carried out in legal exploitation within harvesting plans or programs when the intermediaries purchase timber from plots that are adjacent to those authorized to formal logging. The second, possibly more frequent, involves timber that is obtained informally, "at the edge of the road" or "at the edge of the river".

The timber that is laundered according to the second form is mobilized through an extensive network of small depots and sawmills established within the communities or in the outskirts of cities such as Coca and Tena. Generally, the timber is transported by small transportation intermediaries and sold to depots, sawmills or carpentries who transform the pieces into intermediate products for construction or final products, such as furniture and fruit boxes. The processed timber is subsequently mobilized with a purchase receipt to other depots, sawmills or stores where it is sold to the final consumer.

This activity provides the smallholders with quite a lot of flexibility in terms of the volumes to be extracted. The harvested volumes range approximately between 1 and $3 \mathrm{~m}^{3}$. The marketed products are more frequently boards of soft species and simple planks of hard species. The products that are extracted in the smallholdings tend to depend on the previous purchase order of the small intermediaries, who on their part depend on the order of depots, sawmills or carpentries.

Other factor that makes the laundering easier is that since depots, sawmills and carpentries are recognized as micro enterprises by the SRI, they have the possibility to generate purchasing receipts of products. When the timber is sold to these depots and transformed, it can be mobilized as legal timber simply presenting a receipt. This activity is currently being regulated by SAF II. 
others during transport; one does not exclude the others. These strategies are described below.

\subsubsection{During harvesting}

It is difficult to estimate the volume of standing trees to be extracted from a forest. Forest regulations establish that the yield of a tree is $50 \%$ of the timber volume; however, our own assessment suggests that, as a result of mechanical and pathological defects, the waste can reach up to $70 \%$ (chapter 6 ). The forestry advisors interviewed say that the volume of trees at the moment of the forest inventory is usually overestimated, which is one of the first steps in the development of a harvesting program. Along those lines, a technical report on forestry control by the Ministry of Environment of Ecuador (2011) suggests that around $27 \%$ of the irregularities found during field inspections are errors in diameter at breast height $(\mathrm{DBH})$ and height measurements.

\section{"DBH measurements are made with the help of a measuring tape or girth band; however, as a result of the tree shapes, these measurements are not exact. Height is estimated, and there is no technical instrument that helps to achieve greater precision. "Interview to a forestry advisor}

Therefore the amount of waste that has not been recorded by the regulation could be approximately $25 \%$ higher than that estimated in certain species ${ }^{15}$. This percentage, which is not recorded for practical purposes, provides a margin for executors, loggers or smallholders to negotiate for trees from neighboring smallholdings with which they can complete the non-harvested volumes within the approved harvesting programs. This process is considered by the different actors involved in harvesting as an appropriate action to avoid wasting the investment of the forestry advisory payment and the transport quota approved by MAE. Likewise, this exercise gives other smallholders the possibility to sell lower volumes of timber without the need to carry out a harvesting program. This laundering procedure has been explained in Box 1.

\subsubsection{During transport}

According to the interviews, the decision of local traders and intermediaries to continue operating informally depends on the time final buyers or external traders can wait for the ordered timber.

15 Based on data collected in formal and informal operations.
These purchase orders are made through telephone calls, which mobilize the timber and transportation-intermediaries to obtain the volumes of the ordered species. In some cases, intermediaries have harvesting programs that have already been approved, and through which the orders could be covered. Otherwise, the intermediaries need to resort to the approval of new programs or timber laundering.

All the intermediaries interviewed receive better benefits when they transport legalized timber, since this permits them to save money otherwise paid in bribes at control points-approximately USD 10 to 1000 per truck of transported timber, depending on the volume and type of species. Due to long waiting times to obtain harvesting permits, which became longer when MAE decided to inspect all the operations as a result of advisors' and executors' irregularities, intermediaries need to complement legal forestry activities with informal ones to compensate for the waiting time before the approval of harvesting programs. In spite of the fact that bribes or illegal payments are relatively frequent, intermediaries said that they do not enjoy it since it turns into a habit for those who are paid, thus promoting local corruption networks.

Average waiting time for the approval of a harvesting program at MAE technical offices located in the provinces of Orellana and Napo is, according to respondents, three months. The intermediaries interviewed claim that they cannot wait that long, so they buy transport permits of fictitious programs or of programs that have extra volumes of logged timber. Although respondents stated that this is clearly more costly than legalizing harvesting, final buyers' orders often compensate for the costs of legalizing timber, which constitutes a favorable precedent for future transactions.

Another strategy to avoid forest control consists in using the same transport permit several consecutive times. This is possible since there is a difference between the time of approval of permits and timber transport. In SAF I standard transport time was 72 hours, while SAF II estimates the distance in kilometers and the time needed, which is expected to solve this technical defect in forest monitoring. That is why intermediaries in Orellana usually have all the documents needed to transport the timber to other more remote cities, like Huaquillas $(736 \mathrm{~km})$, since in this case the 
timber will have to go through several controls on the way. On the other hand, in Napo, timber end markets like Ambato are closer $(180 \mathrm{~km})$, so the same transport permit was used for several trips in the control points on this stretch, due to the shorter journey.

\subsubsection{After harvesting}

The regulation for PAFSI application establishes a waiting period of at least five years before starting another logging process in the same area. However, changes in the land use of the smallholders are possible. According to interviews, forestry advisors estimate that $80 \%$ of any type of harvesting leads to changes in land use from forest to agriculture, and/or smallholders decide to log the remaining trees informally in the legalized area, benefiting from the roads opened for logging purposes. In this sense, rapid sampling was conducted to determine land use change in properties that applied the standard and are part of SAF between the years 2010 and 2011 (Box 2).

\subsubsection{Other strategies parallel to harvesting}

One of the most interesting cases considered is the use of income from the Logging and Simplified Harvesting Programs (including from laundering) to develop more programs. In accordance with the intermediaries interviewed, this money is used to take the necessary steps to apply for other

\section{Box 2. Land use change after PAFSI implementation \\ Guido Fernández y Walter García}

In the case of the Amazon, in central, Northern and Southern Ecuador, the only legal instrument applied in individual smallholdings is the Simplified Forest Harvesting Program (PAFSI). A PAFSI establishes parameters that regulate the seasons and the frequency of the forest species to be harvested; it consists of the planning of one year of implementation of selective logging of timber with commercial value. When the PAFSI is completed the harvested area has to be immobilized for the following five years, which raises the question of whether the smallholders immobilize the area or not, if they keep harvesting the remaining trees or change the land use. In order to clarify this question with the help of the data base of SAF 2010 and 2011 of the Technical Office of the Ministry of Environment, Regional Napo, a sample was selected of a total of 153 PAFSI that were concluded during these years; they were divided in three categories according to the harvested volume: small $\left(0-50 \mathrm{~m}^{3}\right)$, medium-sized $\left(51-200 \mathrm{~m}^{3}\right)$ and large $\left(\right.$ over $\left.200 \mathrm{~m}^{3}\right)$. The sample was determined randomly from 20 programs that were visited and a process of verification of forest regulation was carried out. The results show that the change in land use was complete in two smallholdings, from forest to pasture and agriculture. The rest admitted having carried out changes in land use subsequent to harvesting with PAFSI, but in other forests that weren't included in the count of legal trees. These results suggest that PAFSI is successful as a protection mechanism of forest cover; however, the results are not conclusive, due to the fact that in $100 \%$ of the smallholdings some part of native forest was converted to other uses. On the other hand, data drawn from 243 surveys to households in 21 communities in the provinces of Orellana and Napo (chapter 6) suggest that after carrying out a PAFSI a change in land use to perennial and annual crops has finally occurred, as the following table 12 shows.

Table 12. Difference in land use change after a PAFSI

\begin{tabular}{|c|c|c|c|c|c|}
\hline Legality & Years & Hectares & $\begin{array}{l}\text { Difference in } \\
\text { hectares }\end{array}$ & $\begin{array}{l}\text { Percentage } \\
\text { difference }\end{array}$ & $\begin{array}{c}\text { Annual } \\
\text { percentage } \\
\text { difference }\end{array}$ \\
\hline \multirow[t]{2}{*}{ With a program $n=28$} & 2006 & 18.26 & \multirow[t]{2}{*}{1.55} & \multirow[t]{2}{*}{$8.48 \%$} & \multirow[t]{2}{*}{$1.4 \%$} \\
\hline & 2012 & 16.71 & & & \\
\hline \multirow[t]{2}{*}{ Without a program $n=32$} & 2006 & 18.07 & \multirow[t]{2}{*}{0.78} & \multirow[t]{2}{*}{$0,32 \%$} & \multirow[t]{2}{*}{$0.36 \%$} \\
\hline & 2012 & 17.28 & & & \\
\hline
\end{tabular}

Source: Own elaboration based on surveys conducted between January and September 2012. 
programs simultaneously. Thus, there is an average of two to four programs per year per intermediary. This procedure is completely legal. Nevertheless, according to the opinion of the actors interviewed, timber intermediaries working on several programs in parallel can offer better prices for timber to smallholders and have the necessary economic capacity to continuously conduct timber harvesting operations. This, in turn, is expressed by specific payments for workers and input suppliers.

Working simultaneously with different harvesting programs also provides the possibility for intermediaries to exchange timber from one place to the other in order to compensate for the lack of timber resulting from pathological or mechanical damage in certain programs. That is, the intermediaries that are able to work with a larger number of programs usually achieve greater flexibility to meet the demands of final buyers more rapidly, which creates faster returns of investment.

\subsection{Evasion of other harvesting regulations}

\subsubsection{Labor standards}

Although control systems for illegal timber trade have improved significantly, there are other forms of non-compliance with regulations, e.g. labor standards. None of the respondents in the interviews made to chainsaw operators, haulers and assistants had a formal contract; therefore, they do not have any social security coverage or extra work benefits under labor laws ${ }^{16}$. Salaries normally depend on the number of pieces sawn or transported, on the number of days worked and the quality of the job. On average, according to the information provided by respondents, the salary of a professional chainsaw operator is USD 800 per month, and that of haulers and assistants USD 350 and USD 300 per month, respectively.

A vast majority of the workers interviewed have less than six years of formal education, so they are not likely to aspire to find a paid job with benefits. Other types of paid jobs in the area, other than

16 According to labor law, every employed person in Ecuador must be assured social security payments and other benefits such as bonus payments. forest harvesting, such as jobs at oil companies, usually require completion of secondary school education and military service. A total of $20 \%$ of those interviewed have the Peasant Insurance (Seguro Campesino) offered by the Ecuadorian State to farmers, and $80 \%$ depend on the Public Service for health care. Only three interviewees were not satisfied with the working conditions because of the non-compliance of payments by timber intermediaries. Most respondents said their salaries are better than the minimum living wage ${ }^{17}$, and this compensates for other benefits they cannot obtain including labor and social security.

\subsubsection{Tax regulations}

Forest regulations require that program executors register their number of Single Tax Payer (RUC) or Ecuador Simplified Tax Scheme (RISE for its acronym in Spanish) within SAF. Most of the smallholders and executors interviewed are included in RISE, which certifies they are small producers or artisans. This register does not demand payment of high taxes, so invoices are sometimes used to transport laundered timber. SAF II expects to reduce the use of invoices for laundering of timber by implementing a more detailed registration at the final destination.

Chapter 4 in this study indicates that approximately $15 \%$ of timber mobilization in 2011 did not have a declared destination or a SRI registry to state their main destination by type of product. Likewise, there is some evidence that the transported volumes reported at the SAF are usually inconsistent with the tax statements to SRI.

\subsubsection{Non-compliance with verbal agreements}

Purchase-and-sale agreements in the case of formal harvesting do not have any written agreement that commits any of the parties to comply with the order and payment. , Labor relations are also formed through a verbal agreement. Under Ecuadorian laws, verbal contracts allow one of the parties to demand the other party's compliance with the agreed obligations. In the case of purchase and sale, e.g. of timber, there is a legal entity called Judicial Confession (Confesión Judicial), which is

17 The minimum salary at the time of the study was USD 292, apart from compulsory payment of USD 62.34 for social security by the employer and employee, included in the minimum wage. 
based on defendants' "good faith" to declare under oath that they carried out the timber sale or purchase.

The interviews identified intermediaries who had not met their obligations of payment to smallholders and smallholders who had not complied with the delivery of the ordered timber. However, the parties took no legal action to try to recover the investment made both in money and labor. Signing a purchaseand-sale contract under legal terms would not be difficult for intermediaries, but the actors interviewed acknowledge not having appropriate training for this type of action. Intermediaries mainly have conflicts with smallholders. "The lack of seriousness that can be seen in some smallholders has made them waste money and time" (Interview to an intermediary), since verbal agreements regarding the time and quality of the order are not respected. Community authorities added that smallholders are often victims of deceit by intermediaries who do not complete the payments or simply disappear with the sawn product.

\subsection{SAF effectiveness in the context of intermediation}

Progress since 2008, when SAF was implemented, has been significant, especially in terms of the administration of the information that has made possible the collection of forest statistics in real time. However, as discussed in this chapter, the creation of SAF has not been enough to overcome forest users' informality strategies.

SAF I provided an opportunity to explore new control possibilities by requiring executors' and buyers' RUC number. SAF II complemented this activity with the possibility of verification at the timber destination. Nonetheless, as discussed in this chapter, informal trade adapts its sale strategies by means of small periurban depots that process timber and issue a sale invoice, so in these cases timber is not incorporated in the SAF register, but it can be included in declarations to SRI. SAF II provides a platform to cross-check the data with data from SRI, where these cases can be detected, provided that an invoice is issued.
Thus, SAF II expects to control the destination in depots by means of the transport permit with the respective species and volume. Although this inspection can be effective to control the chain of custody, it will not be able to ensure that it is the only source of timber supply for depots in cities like Quito and Cuenca, where demand for native forest timber tends to be higher (see Vásquez, 2011). As mentioned by the actors in this chapter, legal timber permits take longer than necessary to be processed, but orders "do not wait", so it can be inferred that there will be formal and informal timber despite any control, at least until the whole market can be supplied with timber from a legal origin.

Another important aspect within this framework is the role of the forestry advisors. The Forestry Advisory system is a MAE contribution to improve knowledge of regulations on the field, and it is an essential part of the control system and SAF. However, being independent professionals, they do not have the resources to invest in technology or information transfer to users. In the network analysis in this chapter, it can be noted that forestry advisors are an essential element in the intermediation processes between smallholders and intermediaries, apart from providing information on prices. In the rural context, they are one of the few stakeholders that provide some kind of forest management advice for smallholders. SAF is not part of a technology package associated with control implementation, so it leaves a void that prevents users who own forests from making use of this tool.

Both SAF I and SAF II have made an effort to make improvements in the traceability of formal timber, but this is not enough to ensure that users actually adopt this technology, or that this tool is better adapted to local scenarios. What SAF has generated at the local level in the nearest urban centers, like Tena and Coca, is that third parties have taken up the use of the system available on line, charging the local users (intermediaries and smallholders) a fee for their services, which ultimately leads to an increase in transaction costs. 


\title{
Domestic timber market
}

\author{
Alfredo Carrasco, Cristian Terán, Emilia Crespo, and Elena Mejía
}

This chapter analyzes the magnitude and dynamics of harvesting and of the different timber trade flows according to official information from SAF for 2011, which is complemented with information from the Internal Revenue Service (SRI for its acronym in Spanish). While information from SAF shows the volumes harvested and transported per origin and destination, SRI information makes it possible to determine the characteristics of legal and natural persons, according to the Tax Identification Number (RUC for its acronym in Spanish), registered in the system. The combination of these data helps provide a more comprehensive perspective regarding the main characteristics of timber trade flows associated with the different types of timber sellers and buyers for Ecuador as a whole. Part of the analysis in this chapter refers to Ecuador as a whole, while there are specific sections that only refer to the supply in the Amazon region.

\subsection{Timber harvesting per forest type and species}

\subsubsection{Harvesting in Ecuador per region}

According to official MAE data, obtained from SAF records, the harvesting of 2.8 million $\mathrm{m}^{3}$ of timber was authorized in 2011, of which only 2 million $\mathrm{m}^{3}$ was transported (Table 13) ${ }^{18}$. Further, the greatest timber volume was transported in the Coast region (49\%), followed by the Highlands (38\%) and finally the Amazon (12\%). The largest timber supply comes from forest plantations, both in the HIghlands and in the Coast which contribute $65 \%$ of the overall transported volume. Timber harvested in native forests comes from the Coast and the Amazon, which accounts for $12 \%$ of the national total. Last,

18 The fact that only a portion of the overall volumes approved is transported is mainly due to the waste from standing trees (harvested) to logged trees (transported), especially as a consequence of pathological or mechanical damage to the wood, apart from sawmilling waste. agroforestry systems, pioneer formations and others mainly located in the Coast and the Highlands, amount to the remaining 23\%. Generally speaking, it can be said that the region of the Highlands has little or almost no timber harvesting in primary or secondary forests, while the Amazon region appears as a region where forest plantations have not been developed. In the Coast timber harvesting is more diverse since it takes place in different types of forests.

According to MAE, cited by Grijalva, et al., (2012), the following were the ten most harvested species between 2008 and 2009: balsa (Ochroma pyramidale, lagopus), laurel (Cordia alliodora), pigüe (Piptocoma discolor), sande (Brosimum utile), and chalviande (Virola sebifera). Among the main exotic species, the following can be found: Eucalyptus (Eucalyptus globulus), pine (Pinus radiata and Pinus patula), pachaco (Schizolobium parahybum), teak (Tectona grandis), and melina (Gmelina arborea). According to SAF 2010 and SAF 2011 data, these species are still the most harvested ones, particularly Otoba spp. Some remarkable species that are important for the construction industry are chuncho (Cedrelinga catenaeformis) and colorado (Guarea kunthiana).

\subsubsection{Harvesting in the Amazon by forest type}

Forest harvesting in the Amazon increased from $357,000 \mathrm{~m}^{3}$ in 2007 to $458,000 \mathrm{~m}^{3}$ in 2011

(Ministerio del Ambiente, 2010; Ministerio del Ambiente, 2011). Timber harvested in this region supplies the timber demand for the furniture and construction industries mainly in Quito, Cuenca and Ambato markets (Vásquez, 2011). In 2011, out of a total of $458,000 \mathrm{~m}^{3}$ of approved timber in the Amazon, only 246,000 $\mathrm{m}^{3}$ was transported (Table 14). 35\% of the overall figure of transported timber was extracted under PAFSI, which indicates that it was harvested from plots 
Table 13. Forest use by region and forest type in 2011 (in thousand $\mathrm{m}^{3}$ )

\begin{tabular}{|c|c|c|c|c|c|c|}
\hline & \multicolumn{5}{|c|}{ Type of forest (in thousand $\mathrm{m}^{3}$ ) } & \multirow[b]{2}{*}{ Tota } \\
\hline & $\begin{array}{l}\text { Native } \\
\text { forests } \\
\text { (a) }\end{array}$ & $\begin{array}{l}\text { Forest } \\
\text { plantations } \\
\text { (b) }\end{array}$ & $\begin{array}{l}\text { Agroforestry } \\
\text { systems } \\
\text { (c) }\end{array}$ & $\begin{array}{l}\text { Pioneer } \\
\text { formations } \\
\text { (d) }\end{array}$ & $\begin{array}{l}\text { Legal } \\
\text { conversion } \\
\text { (e) }\end{array}$ & \\
\hline \multicolumn{7}{|l|}{ Approved } \\
\hline Coast & 129 & 684 & 535 & 30 & 13 & 1391 \\
\hline Highlands & 1 & 920 & 228 & & 0 & 942 \\
\hline Amazon & 204 & 1 & 20 & 11 & 15 & 458 \\
\hline Total & 334 & 1604 & 784 & 41 & 28 & 2791 \\
\hline \multicolumn{7}{|l|}{ Mobilized } \\
\hline Coast & 121 & 547 & 295 & 30 & 7 & 1000 \\
\hline Highlands & 1 & 768 & 115 & & 0.15 & 780 \\
\hline Amazon & 113 & 0.4 & 11 & 11 & 7 & 246 \\
\hline Total & 235 & 1316 & 420 & 41 & 15 & 2026 \\
\hline
\end{tabular}

Notes: forest types correspond to the following harvesting plans included in the Ecuadorian forest legislation: a) PAFSI: Simplified Forest Management Plan, and PAFSU: Sustainable Forest Harvesting Plan, b) PAFPL: Forest Harvesting Program for Planted Forests, PAFAP: Forest Harvesting Plan for Planted Trees; c) PAFEP: Forest Harvesting Program for Planted Forests (naturally regenerating trees), PCAR: Logging Program for Relict Trees, d) FCB: Balsa Logging Form, FCP: Pigüe Logging Form. These forms are partially covered by SAF; therefore they only represent partial figures; and e) PAFCL: Forest Harvesting Program for Legal Conversion.

Source: Own elaboration based on SAF, Ministry of Environment of Ecuador (2011).

Table 14. Amazon: Use by type of program in 2011 (in thousand $\mathrm{m}^{3}$ )

\begin{tabular}{|c|c|c|c|c|c|c|c|}
\hline & \multicolumn{6}{|c|}{ Type of program (in thousand $\mathrm{m}^{3}$ ) } & \multirow{3}{*}{ Total } \\
\hline & \multicolumn{3}{|c|}{ Plantations } & \multicolumn{2}{|c|}{ Native forests } & \multirow{2}{*}{ Other ${ }^{f}$} & \\
\hline & PAFPL ${ }^{a}$ & PAFAPb & PCAR $^{c}$ & PAFSI $^{d}$ & PAFSU & & \\
\hline Approved (in thousand $\mathrm{m}^{3}$ ) & 0.5 & 94.3 & 133.9 & 173.6 & 30.5 & 25.3 & 458 \\
\hline Approved (\%) & 0.1 & 20.6 & 29.2 & 37.9 & 6.7 & 5.5 & 100 \\
\hline Mobilized ( in thousand $\mathrm{m}^{3}$ ) & 0.4 & 47.2 & 67.9 & 86.8 & 25.8 & 18.0 & 246.2 \\
\hline Mobilized (\%) & 0.2 & 19.2 & 27.6 & 35.3 & 10.5 & 7.3 & 100 \\
\hline
\end{tabular}

Notes: a) PAFPL: Forest Harvesting Program for Planted Forests, PAFAP: Forest Harvesting Plan for Planted Trees, b) PAFEP: Forest Harvesting Program for Planted Forests (naturally regenerating trees) / Logging Program for Pioneer Species, c) PCAR: Logging Program for Relict Trees, d) PAFSI: Simplified Forest Harvesting Plan; e) PAFSU: Sustainable Forest Harvesting Plan; f) FCB: Balsa Logging Form, FCP: Pigüe Logging Form, PAFCL: Forest Harvesting Program for Legal Conversion.

Source: Own elaboration based on data from SAF, Ministry of Environment of Ecuador (2011).

owned by smallholders, as was the timber extracted through relict programs (27\%), followed by timber from cultivated forests or naturally regenerated forests (19\%). Although use of PAFSU is not very important in the Amazon, $10 \%$ of the timber was extracted through mechanized operations.
A larger share of the timber originating in the Amazon comes from the provinces of Sucumbíos and Orellana (Figure 5), in northeastern Ecuador and northern Amazon, while smaller harvesting operations are conducted in the provinces in central and southern Amazon. In general terms, 


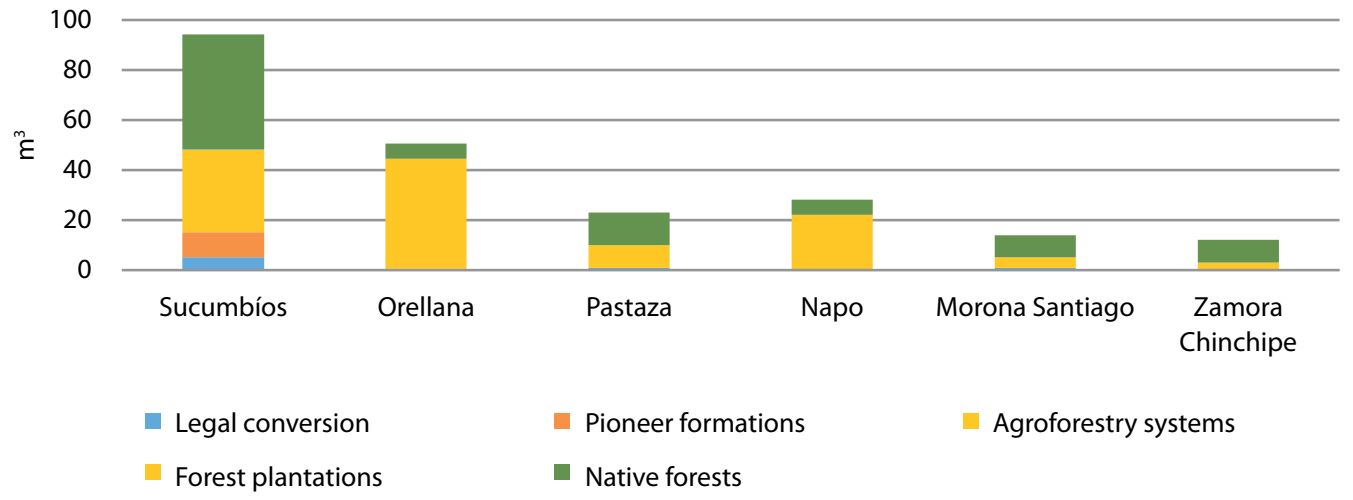

Figure 5. Amazon: Harvested volume (in $\mathrm{m}^{3}$ ) by forest type and province. The data are grouped by Native forests (PAFSU and PAFSI), Forest plantations (PAFAP and PAFPL), Agroforestry systems (PCAR and PAFEP), Pioneer formations (FCB and FCP) and Legal land conversion (PAFCL). Personal compilation based on SAF, Ministry of Environment of Ecuador (2011).

the fact that there is a bigger timber supply in the provinces of Sucumbíos and Orellana is closely related to the greater development of roads associated with the oil extraction activities that have been carried out in these provinces and to the subsequent migration that has implied greater pressure on forest resources (Wunder, 2000; Wunder, 2003).

An important aspect that is worth highlighting is related to the harvested species and their origin. Table 15 shows the main species (hard, semi-hard and soft) coming from Amazon forests associated with the different programs used. Thus, $50 \%$ of the most commercial species come from native forests, $30 \%$ from agroforestry systems and $27 \%$ from pioneer formations. The most harvested hard and semi-hard species include laurel, chuncho, arenillo, colorado, and copal, which are used in furniture and flooring industries. The most harvested soft species are doncel, sapote, coco and tamburo, whose main destination is plywood and construction industries. In accordance with SAF, harvesting programs authorized the harvesting of a total figure of 222 species in 2010 and around 300 in 2011 (SAF 2010, 2011). The increase in the number of species is a phenomenon that is probably due to the reduction in the volumes of certain species that have been more intensely harvested and increased market demand for timber, thus forcing new species to enter the market, such as Otoba spp. This could also be due to the misidentification of species.
There are three species with important economic value for smallholders: laurel, chuncho and doncel. The first of these species, laurel, reported transported volumes of $39,200 \mathrm{~m}^{3}$ in 2010 and $42,100 \mathrm{~m}^{3}$ in 2011 . In the case of chuncho, 16,100 $\mathrm{m}^{3}$ were reported in 2010 and $10,900 \mathrm{~m}^{3}$ in 2011 .

Laurel (Cordia alliodora), a species harvested from agroforestry systems, represents $17.3 \%$ of the overall transported volume in the Amazon. An analysis of legal harvesting figures shows that $96.75 \%$ came from PAFEP, a program that allows for the harvesting of naturally regenerated trees since the species develop in areas that have been intervened or transformed into pastures, since they need much solar radiation to reach appropriate growth.

Doncel (Otoba spp.) harvesting has recently increased, reporting volumes of $9300 \mathrm{~m}^{3}$ in 2010 and 16,000 in 2011. It ranks second in terms of timber harvested in the Amazon, with $6.5 \%$ of the total transported volume. The most widely used legal figure for doncel harvesting was PAFSI with $41.39 \%$ of the total transported volume, followed by PCAR with $33.27 \%$, together amounting to $75 \%$ of the timber in the country's market. Its timber, considered ordinary in the market, is used for all types of construction activities. In Sucumbíos, this species is used to manufacture broomsticks, and in Pastaza it is used to make pallets (Ministerio del Ambiente, 2011). 
Table 15. Amazon: Use by type of program and species in 2011

\begin{tabular}{|c|c|c|c|c|}
\hline \multirow[b]{2}{*}{ Species } & \multicolumn{4}{|c|}{ Harvested volume (in thousand $\mathrm{m}^{3}$ ) } \\
\hline & $\begin{array}{l}\text { Native } \\
\text { forests }\end{array}$ & $\begin{array}{l}\text { Agroforestry } \\
\text { systems }\end{array}$ & $\begin{array}{l}\text { Pioneer } \\
\text { formations }\end{array}$ & Total \\
\hline Laurel (Cordia alliodora) $\left(^{*}\right)$ & 0.3 & 42.1 & 0 & 42.4 \\
\hline Doncel, sangre de gallina, (Otoba spp.) & 16.5 & 8.9 & 0 & 25.4 \\
\hline Sapote (Sterculia spp.) & 8.1 & 5.4 & 0 & 13.5 \\
\hline Balsa, boya (Heliocarpus americanus) & 0.1 & 0 & 10.6 & 10.7 \\
\hline Chuncho, seique (Cedrelinga catenaiformes) (*) & 9 & 1.9 & 0 & 10.9 \\
\hline Ceiba, ceibo (Ceiba insignis) & 7.9 & 5.3 & 0 & 13.2 \\
\hline Chalviande, coco (Virola spp.) & 6.2 & 3.6 & 0 & 9.8 \\
\hline Arenillo, pondo (Erisma uncinatum) $(*)$ & 7.3 & 2 & 0 & 9.3 \\
\hline Tamburo, Bella María, Juan Colorado (Vochysia spp.) & 4.9 & 2.8 & 0 & 7.7 \\
\hline Colorado, manzano, piaste (Guarea kunthiana) $(*)$ & 3.6 & 2.9 & 0 & 6.5 \\
\hline Copal, copalillo, anime, pulgande (Dacryodes spp.) & 4.2 & 1.5 & 0 & 5.7 \\
\hline Jigua, canelo (Jigua spp.) & 3.7 & 1.3 & 0 & 5 \\
\hline $\begin{array}{l}\text { Algodón, lao, ceibo rojo, ceiba, sumauma } \\
\text { (Ceiba spp.) }\end{array}$ & 2.7 & 2.4 & 0 & 5.1 \\
\hline Lechero, sande rojo, sande blanco (Brosimun spp.) & 3.2 & 1.5 & 0 & 4.7 \\
\hline Guarango, yonrunta (Acacia glomerosa) & 2.7 & 1.7 & 0 & 4.4 \\
\hline Matapalo, higuerón (Ficus spp.) & 1.8 & 2.2 & 0 & 4 \\
\hline Abio, caimitillo (Pouteria spp.) & 2.2 & 1.6 & 0 & 3.8 \\
\hline $\begin{array}{l}\text { Canelo, alcanfor, jigua, amarillo, canelón (Ocotea } \\
\text { spp.) (a) }\end{array}$ & 1.7 & 1.8 & 0 & 3.5 \\
\hline Guayabillo, yunyun, roble, winegro (Terminalia spp.) & 1.2 & 2.3 & 0 & 3.5 \\
\hline Copal, anime (Dacryodes peruviana) & 2.2 & 1.1 & 0 & 3.3 \\
\hline Damagua, majagua, yamila (Poulsenia armata) & 2.6 & 0.4 & 0 & 3 \\
\hline $\begin{array}{l}\text { Cutanga, guarango, cacepo, tankam, yurutz } \\
\text { (Parkia multijuga) }\end{array}$ & 1.5 & 1.4 & 0 & 2.9 \\
\hline Guabillo (Inga spp.) & 2.2 & 0.3 & 0 & 2.5 \\
\hline Guaba, guabo (Inga spp.) & 1.5 & 0.7 & 0 & 2.2 \\
\hline Other & 24.2 & 18 & 0 & 42.2 \\
\hline Other species from legal conversion & & & & 0.6 \\
\hline Other species from forest plantations & & & & 0.4 \\
\hline Total & 121.5 & 113.1 & 10.6 & 246.22 \\
\hline
\end{tabular}

Note: Species marked with an * belong to hard or semi-hard species; the others are considered softwood species.

Source: Own elaboration based on SAF, Ministry of Environment of Ecuador (2011).

Chuncho or seike (Cedrelinga catenaeformis) is a highly demanded species that is harvested in native forests and mainly used for doors and doorframes. According to SAF (2011), it represents $4.5 \%$ of the overall transported volume in the Amazon. It is worth mentioning that the type of pressure exerted on the species as a result of its current extraction is unknown. This species has no restriction in CITES. It is especially marketed for doors and floors, products that are exported to regional markets like Venezuela. 
Table 16. Ecuador: Destination and origin of the mobilized timber in 2011

\begin{tabular}{|c|c|c|c|c|c|c|c|}
\hline & & \multicolumn{6}{|c|}{ Destination (in thousand $\mathrm{m}^{3}$ ) } \\
\hline & & Coast & Highlands & Amazon & Galápagos & Not specified & Total \\
\hline \multirow{3}{*}{ 듬 } & Coast & 591 & 224 & 7 & 0.1 & 178 & 1000 \\
\hline & Highlands & 232 & 448 & 1 & 0 & 99 & 779 \\
\hline & Amazon & 27 & 185 & 19 & 0 & 15 & 246 \\
\hline \multicolumn{2}{|c|}{ Total } & 850 & 857 & 27 & 0 & 292 & 2025 \\
\hline
\end{tabular}

Source: Own elaboration based on SAF, Ministry of Environment of Ecuador (2011).

\subsection{Main timber trade flows}

\subsubsection{Origin and destination of timber transported at the provincial level}

Flows of timber in Ecuador are relatively complex since timber from production areas in the Coast, the Highlands and the Amazon is taken to different local and regional markets and markets outside the country. The Highlands and the Coast regions receive most transported timber- $43 \%$ and $42 \%$ respectively_- and most of the Amazon production is marketed outside this region

(Table 16). Most of the timber consumed in the Coast comes from the same region; part of it comes from the Highlands mainly from plantations.

The Highlands is also an important consumer of timber originating in the region itself, especially eucalyptus and pine plantations, since the industry of plywood sheets is concentrated here. Nevertheless, native forests in the Amazon are also important timber sources for furniture markets in the region (Ministerio del Ambiente, 2011).

Although timber trade flows to the interior of each of the regions are important, there is also significant timber trade between the different regions. The main timber trade flows identified (Map 3) are detailed by region below:

- In the Coast: Guayas, Esmeraldas and Los Ríos are the main consumption centers. Guayas receives timber mainly from Esmeraldas-an average $200,000 \mathrm{~m}^{3}$ in 2011. At the same time, Esmeraldas receives timber from forest plantations in Pichincha and Cotopaxi for the export wood chip industry. Timber intended for these markets is mainly used in the plywood industry in Esmeraldas and for use in the furniture and construction industries in Guayas and Los Ríos (Ministerio del Ambiente, 2011).

- In the Highlands: the main consumption centers are the provinces of Pichincha and Cotopaxi, where the company Aglomerados Cotopaxi (ACOSA), which consumes an important part of this timber, is located. In 2011 Pichincha consumed over $400,000 \mathrm{~m}^{3}$ of timber coming from the provinces of Esmeraldas, Cotopaxi, Sucumbíos and Orellana, just to mention the most important ones. In turn, Cotopaxi consumed approximately $188,000 \mathrm{~m}^{3}$ of timber in $2011,151,000 \mathrm{~m}^{3}$ of which was internally produced. It is worth noting that most artisan furniture makers are concentrated in this region in Azuay and Pichincha (around 80\% are members of CAPIA $^{19}$ and CAPEIPI ${ }^{20}$ ). These artisans are mainly supplied with timber coming from Esmeraldas, of the Fernán Sánchez (Triplaris cumingiana) species, which is the timber most widely used in furniture manufacturing, followed by the species from the Amazon (Terán, 2012).

- In the Amazon: the provinces of Sucumbíos and Orellana supply Pichincha with timber, and to a lesser extent, Orellana supplies the Guayas markets, especially with export timber, such as chuncho (Cedrelinga cateniformeis) used for door manufacturing. The other provinces in this region (Napo, Pastaza, Morona Santiago and Zamora-Chinchipe) supply smaller markets like Ambato, Cuenca and Loja. The timber for these markets is used primarily in the furniture and construction industries. Table 17 below shows the main destinations of the most harvested species in the Amazon, and Map 4 shows the general flows of the timber destinations.

19 Chamber of Small Industries of Azuay (Cámara de la Pequeña Industria del Azuay).

20 Chamber of Small and Medium-sized Enterprises of Pichincha (Cámara de la Pequeña y Mediana Empresa de Pichincha) 


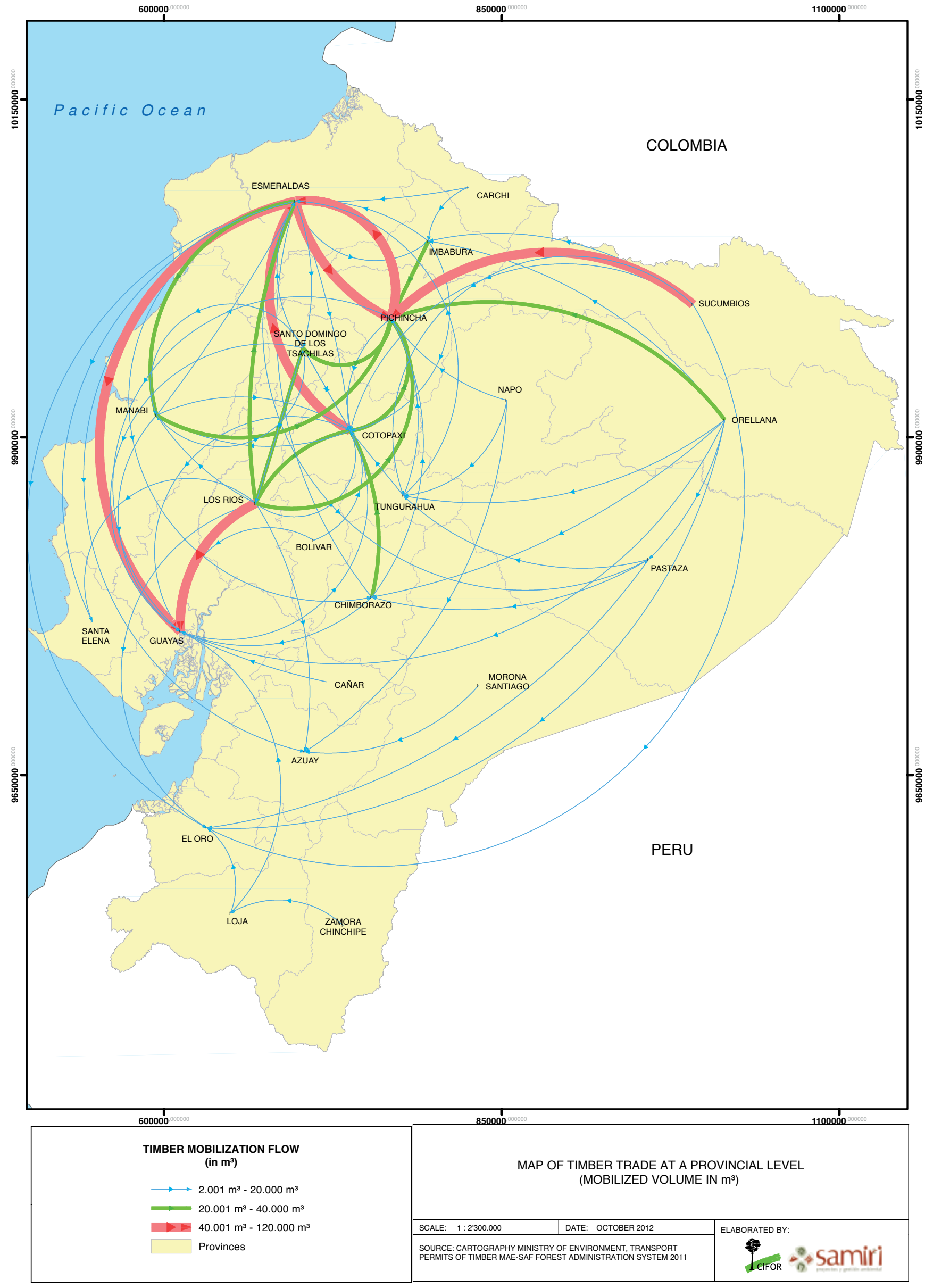

Map 3. Ecuador: Timber trade at the province level elaborated according to data from SAF, Ministry of Environment of Ecuador (2011) 
Table 17 Main mobilized species in the Amazon and their destinations

\begin{tabular}{ll}
\hline Species & Main Destination \\
\hline Laurel (Cordia alliodora) & Tungurahua, Pichincha, Imbabura \\
Doncel, sangre de gallina, (Otoba spp.) & Pichincha, El Oro, Pastaza \\
Sapote (Sterculia spp.) & Pichincha, Imbabura, Sucumbíos, Pastaza \\
Balsa, boya (Heliocarpus americanus) & El Oro, Guayas \\
Chuncho, seique, (Cedrelinga catenaiformes) & El Oro, Guayas, Pichincha, Tungurahua, Loja \\
Ceiba, ceibo, (Ceiba insignis) & Pichincha, Tungurahua, Imbabura \\
Chalviande, coco, (Virola spp.) & El Oro, Pichincha, Tungurahua, Pastaza \\
Arenillo, pondo (Erisma uncinatum) & El Oro, Pichincha, Tungurahua, Imbabura \\
Tamburo, bella María, Juan Colorado (Vochysia spp.) & El Oro, Pichincha, Tungurahua, Chimborazo \\
Colorado, manzano, piaste (Guarea kunthiana) & Pichincha, Tungurahua, El Oro \\
Copal, copalillo, anime, pulgande (Dacryodes spp.) & Azuay, Pichincha, Tungurahua \\
\hline
\end{tabular}

Source: Own elaboration based on SAF, Ministry of Environment of Ecuador (2011).

\subsubsection{Origin and destination of timber transported in the Amazon}

As it has already been mentioned, the six Amazon provinces transport $12 \%$ of timber supply. Of this, $46 \%$ originates in native forests (harvested through PAFSI and PAFSU programs), 28\% is timber harvested in agroforestry systems and 19\% comes from pioneer formations. The share of timber that is locally consumed in the Amazon is relatively small $\left(8 \%\right.$ or $19,000 \mathrm{~m}^{3}$ in 2011$)$, which means that $92 \%$ is consumed in the Coast and the Highlands (Box 16). The province of Sucumbíos is the one contributing the largest amount of timber (38\%), followed by Orellana (30\%) and the other four provinces (22\%).

It is estimated that an important portion of the timber consumed locally in the Amazon is of informal origin. For instance, Palacios (2008) notes that the amount of locally marketed timber in Napo is higher than that of legally declared timber, suggesting that approximately $80 \%$ of the timber sold in Tena is of informal origin. In turn, Sierra (2000) suggests that local markets are very important in timber marketing for small producers, and that an important part of the supply comes from the informal market.

The only industry located in the Amazon region is Arboriente S.A. This company is mostly supplied with roundwood for its plywood plant (Ministerio del Ambiente, 2011). Thus, the majority of the timber that originates in the Amazon is transported to other regions where timber industries are concentrated, such as the province of Pichincha
(Figure 6). Likewise, as discussed above, the furniture industry that is concentrated in the provinces of Azuay and Pichincha are supplied with timber from the Amazon (Vásquez, 2011; Terán, 2012).

The provinces that receive timber from the Amazon with volumes over $10,000 \mathrm{~m}^{3} /$ year are Pichincha, Tungurahua, Imbabura, El Oro, and Azuay (Figure 6).

- The province of Tungurahua receives timber from the province of Napo (85\%), which is due to the proximity and accessibility to transport timber along the main road, apart from the fact that this province promotes large-scale furniture manufacturing (Terán, 2012).

- In turn, the province of Imbabura receives $49 \%$ of the timber from the agroforestry systems located in Orellana province, whose final destination is San Antonio de Ibarra where wood artisans and carpenters are concentrated.

- The province of El Oro receives timber from Sucumbíos and Orellana. This transport occurs despite the distance because of the demand and differentiated prices for sawn timber in Huaquillas (Box 3).

- Azuay is the only province that receives an important volume from the province of Morona Santiago.

- Finally, although in smaller volumes, timber from Zamora Chinchipe is one of the few sources of timber taken to the province of Loja (Map 4). Further, the Ministry of Environment of Ecuador (2011) states that semi-processed timber is transported from Loja to Cuenca and Huaquillas (Map 5). 


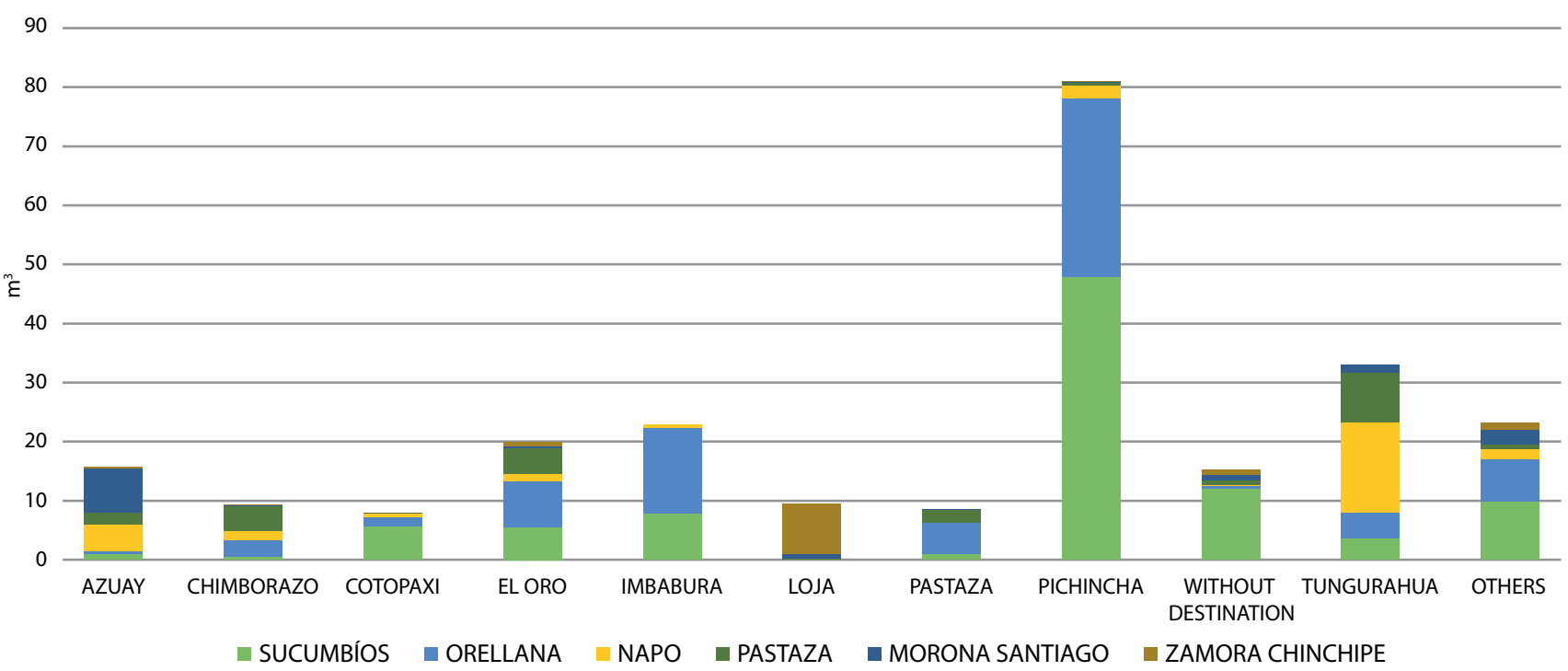

Figure 6. Amazon: Transported timber according to province of origin and 10 main destinations (thousand $\mathrm{m}^{3}$ ). Personal compilation based on SAF, Ministry of the Environment of Ecuador (2011).

\section{Box 3. Trade of timber with final destination in Huaquillas}

Patricia Aguirre, Johanna Morocho y Santiago Alarcón

According to Salazar (2006), one of the borders with most timber trade in Ecuador is that of Huaquillas constituting a center of regular timber trade, generally through smuggling. Huaquillas is one of the principal markets of the timber originating in the provinces of Orellana, Sucumbíos and Pastaza $(38,6 \%, 24,1 \%$ and $23,1 \%$, respectively, of the timber mobilized to Huaquillas). $58 \%$ of this timber comes from native forests (SAF 2011), and is cleaned and measured by local sawmills to be later marketed in Peru (Ministry of Environment of Ecuador, 2011). Despite that there are official figures available on the entry of timber marketed in Huaquillas, the final destination of this timber is unknown, as is the dynamics of its marketing in Peru. To make up for this lack of information, interviews were carried out to 13 of a total of 18 establishments registered in SAF located in the canton of Huaquillas, that received timber in 2011. According to SAF and SRI, 14 of these establishments would be classified as depots that received $59,9 \%$ of the timber, and 4 are sawmills that received $34,1 \%$.

According to the interviewees, the timber comes mainly from Coca (Orellana province) and Lago Agrio (Sucumbíos province). The timber volume that they receive in their sawmills has been reported as an average of two trucks per month, approximately $60 \mathrm{~m}^{3}$ in total. The interviews with owners of sawmills and depots indicate that $53 \%$ of the timber remains in Huaquillas and the remaining $47 \%$ would be destined to Peru. Nevertheless, according to complementary interviews with local actors, the domestic demand isn't as high as previously suggested. The timber that is marketed in Peru is transported with tricycles in small quantities to avoid control points. It often isn't unloaded in Huaquillas and goes directly to Peruvian territory during early morning hours with final destination in the city of Piura and sometimes Chiclayo.

The owners of deposits and sawmills in Huaquillas indicate that the species with the highest demand in Peru are the semihard, among them: chuncho (Cedrelinga cateniformis), sangre de gallina (Otoba spp.) and arenillo (Erisma uncinatum). It is also indicated that the principal product are boards destined for construction, though they often arrive in the form of simple planks which are subsequently measured. The biggest problem that these establishments face is the lack of compliance with the agreements regarding the quality of the timber with intermediaries, especially when it comes to the straightness and dimensions of the timber; sometimes this timber has mechanical or pathological defects which reduce its price in the end market. 


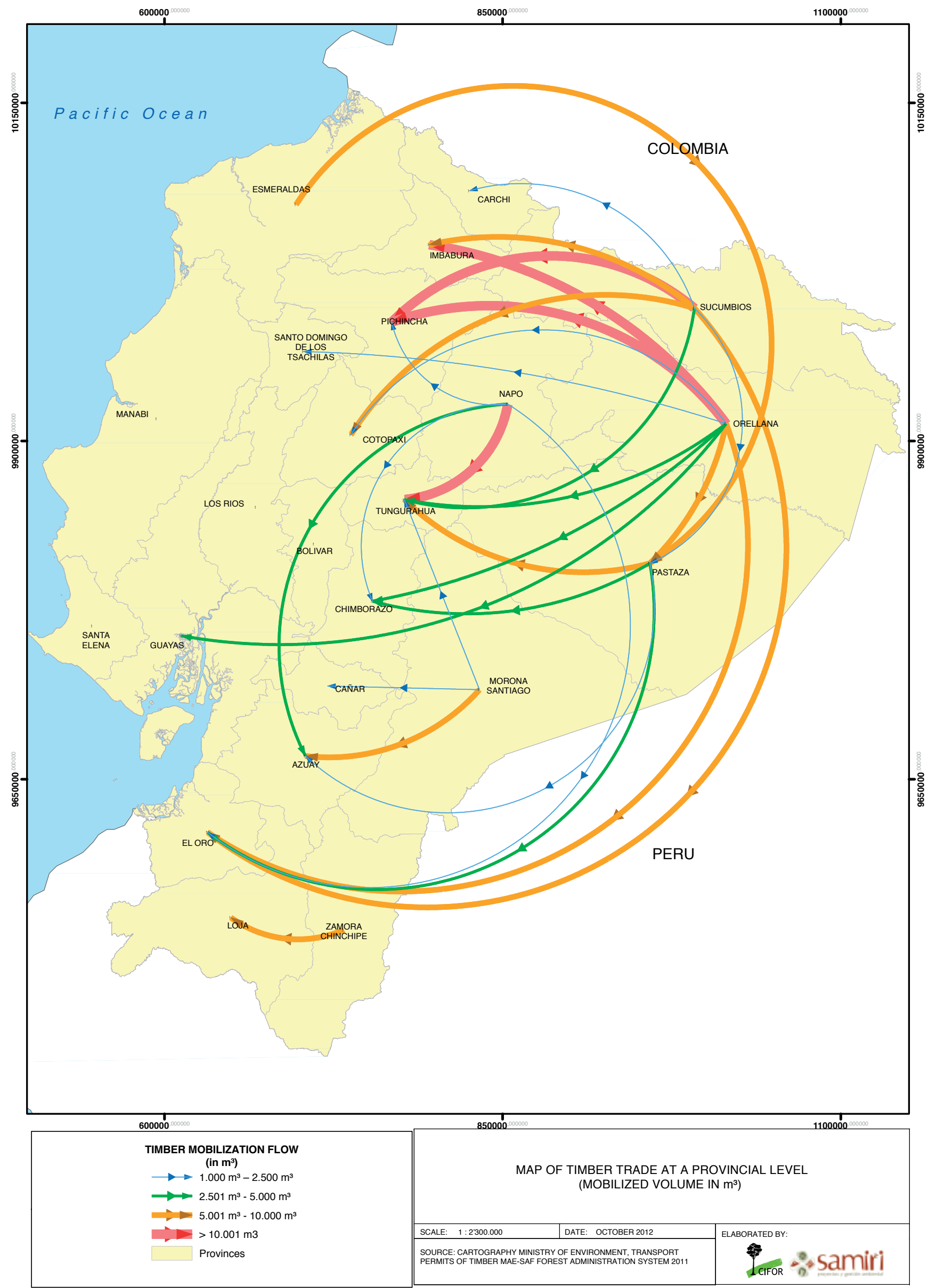

Map 4. Amazon: Major timber trade flows at the province level, elaborated according to information from SAF, Ministry of Environment of Ecuador (2011). 


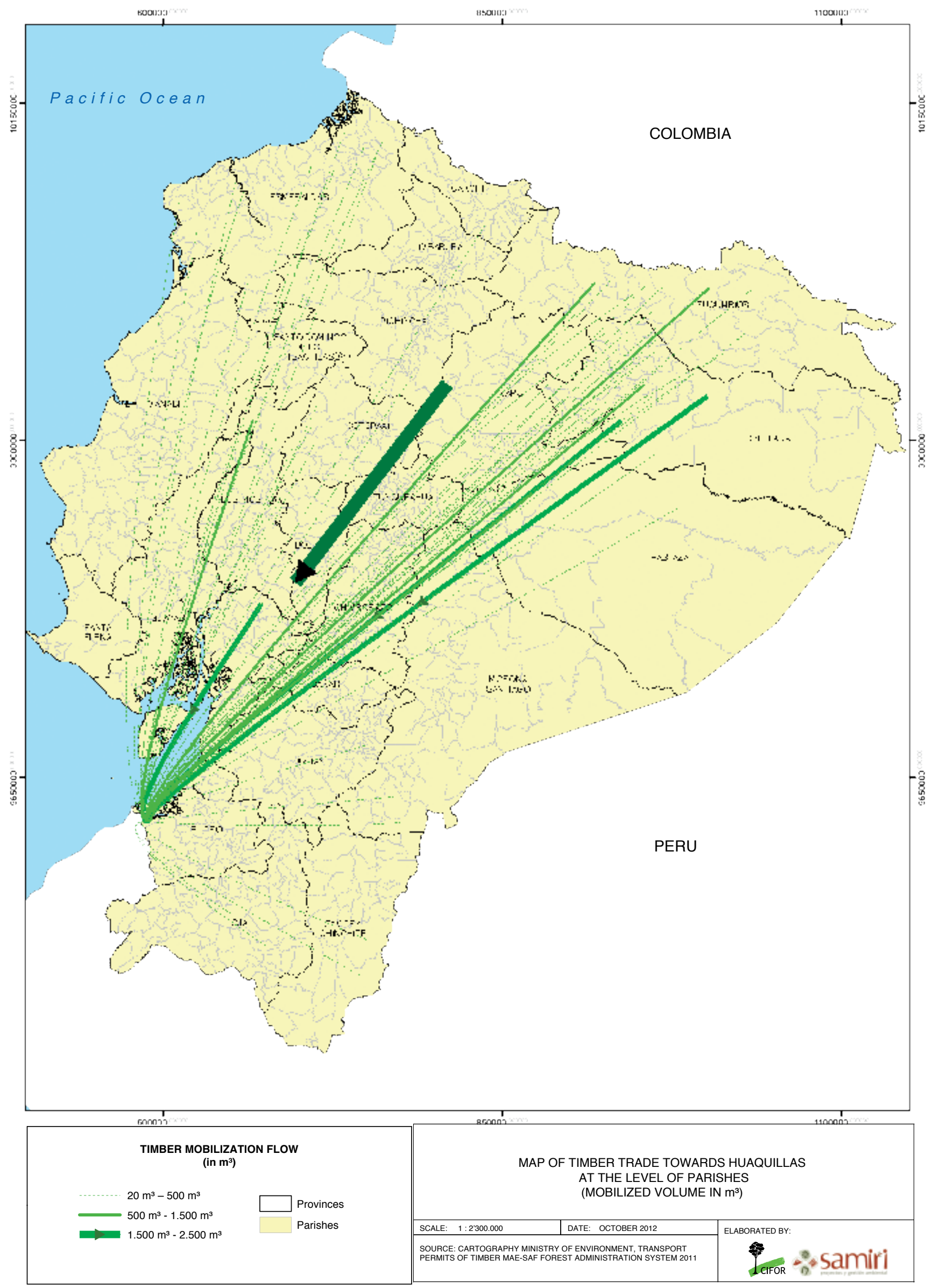

Map 5. Origin of timber with final destination in Huaquillas, elaborated according to information from SAF, Ministry of Environment of Ecuador (2011). 


\subsection{A description of suppliers and buyers}

\subsubsection{Executors and buyers per item and size at the national level}

A total of 3053 executors who have been registered in SAF received transport permits in $2011.86 \%$ of them are registered in SRI as natural persons while the rest are legal persons, known as companies or firms. ${ }^{21}$ Executors are those who, according to the database, perform timber harvesting operations ${ }^{22}$. Additionally, SAF has registered 3559 timber buyers. The interactions established by executors and buyers according to this information are presented below.

In 2011, the most important types of executors considering the volume of mobilized timber are those classified as depots, sawmills and transporters, as shown in Table 18. The depots are the main suppliers of the domestic market (35\% of the total). They transport timber especially to other depots $\left(238,000 \mathrm{~m}^{3}\right)$, industry $\left(203,000 \mathrm{~m}^{3}\right)$ and other consumers without registered RUCs $\left(102,000 \mathrm{~m}^{3}\right)$. Depots are located in the three regions of the country, although their share in the marketed volume is larger in the Coast (53\%) than in the Highlands (28\%) and the Amazon (19\%). A fact that is still surprising is that, although the timber supply is concentrated in the above categories of economic establishments, there is a considerable number of executors with quite diverse activities (for instance, mining, agriculture, livestock and food) that are also devoted to timber sale and/or intermediation.

The most significant timber buyers (per item) are industries, depots, sawmills, and carpentries (Table 19). In addition, there is a wide variety of buyers that have their RUC registered in an important number of economic activities. The industry consumes almost half of the timber that enters the formal market $\left(905,000 \mathrm{~m}^{3} /\right.$ year), and it is mainly located in the Coast and the Highlands, while in the Amazon, this industry is virtually nonexistent. The establishments registered as depots are also an important group in terms of timber

21 Only two implementers registered in SAF database are not registered in SRI.

22 However, implementers are rarely the owners of forests, but rather they act as intermediaries or have some family relation with them. demand; they may then sell the timber to direct consumers, or re-sell it to other establishments in the sector including other depots and sawmills. In turn, carpentries do not constitute a relevant group of establishments as direct timber buyers, since they probably establish commercial relations with the depots or sawmills to be supplied with the timber needed (Table 20).

According to a classification by executor size, pursuant to the criteria in Table 18, most of the supply is concentrated in "very large" and "large" executors. As mentioned above, an important portion of the timber mobilized by executors comes from forest plantations. "Very large" executors harvest native forests only through mechanized operations under PAFSU programs. "Large" and "medium-sized" tend to harvest timber from different types of forests under different harvesting plans (Figure 7). Regarding buyers, most of them are "very large" and "medium-sized". "Very large" buyers mostly purchase timber from plantations, while "large" and "medium-sized" buyers' demand is partly met with timber from native forests (Figure 8). Both executors and buyers that are classified as "small" represent a very small share both in timber supply and demand.

An analysis of trade flows between executors and buyers, considering the size of buyers' operations, shows that "very large" buyers-those who dominate the market together with "large" buyers-are supplied mainly by timber depots and service providers, companies possibly devoted to industrial forest harvesting. Nevertheless, "medium-sized" buyers are mainly supplied by sawmills and transporters. This is likely to be a less structured market where a larger number of actors intervene, as can be seen in Box 21 .

\subsubsection{Executors and buyers per item and size in the Amazon}

Data analyzed by SAF in 2011 suggest that depots are the main timber supplier and buyer in the Amazon. These data reinforce the findings of the Ministry of Environment of Ecuador (2001), which suggest that most timber in the region is marketed by depots and sawmills. In spite of the fact that most timber in the Amazon comes from smallholders, forest programs are usually processed and implemented by depot and sawmill owners and transporters - most of them registered as natural persons. 
Table 18. Executors by category and size

\begin{tabular}{|c|c|c|c|c|c|c|c|}
\hline \multirow{2}{*}{ Sategory } & \multicolumn{6}{|c|}{ Executors (in thousand $\mathrm{m}^{3}$ ) a } & \multirow{2}{*}{ Total \% } \\
\hline & Very large & Large & Medium & Small & Very small & Overall total & \\
\hline Depot & 28.4 & 393.8 & 256.1 & 30.1 & 0.5 & 708.8 & 35 \\
\hline Transport & 189.4 & 100.9 & 41.6 & 5.1 & 0.1 & 337 & 16.6 \\
\hline Sawmills & 0 & 97.5 & 05.7 & 11.6 & 0.2 & 215 & 10.6 \\
\hline Services & 123.8 & 39.4 & 21.0 & 2.9 & 0.1 & 187.1 & 9.2 \\
\hline Not declared ${ }^{b}$ & 64.7 & 51.6 & 12.1 & 2.4 & 0.2 & 131 & 6.5 \\
\hline Livestock & 52.5 & 7 & 15.6 & 14.1 & 0.2 & 89.3 & 4.4 \\
\hline Industry & 67.9 & 10.1 & 7.2 & 0.3 & 0 & 85.4 & 4.2 \\
\hline Mining & 73.4 & 0 & 0.4 & 0.2 & 0 & 74 & 3.7 \\
\hline Agricultural & 0 & 40.1 & 20.2 & 3.9 & 0.2 & 64.4 & 3.2 \\
\hline Other & 0 & 73.7 & 49.6 & 7.1 & 0.2 & 130.8 & 6.5 \\
\hline $\begin{array}{l}\text { No RUC (Tax } \\
\text { Identification Number)d }^{\text {den }}\end{array}$ & 0 & 2.8 & 0 & 0.1 & 0 & 2.9 & 0.1 \\
\hline Total & 600 & 816.8 & 529.4 & 77.9 & 1.7 & 2025.8 & 100 \\
\hline
\end{tabular}

Note: a) These groups have been classified according to the annual transported volume. Very large: more than 12,000 m3/year; large: 1200,1 to $12,000 \mathrm{~m}^{3} /$ year; medium: 120.1 to $1200 \mathrm{~m}^{3} /$ year; small: 12.1 to $120 \mathrm{~m}^{3} /$ year; very small: 0.1 to $12 \mathrm{~m}^{3} /$ year, b) this means that the executor has not stated the trade name or main business activity in the Internal Revenue Service (SRI), c) it includes all implementers whose trade name or main commercial activity records are not related to forestry, d) no RUC: the RUC stated in SAF is not registered in SRI.

Source: Own elaboration based on SAF, Ministry of Environment of Ecuador (2011).

Table 19. Buyers by size and category

\begin{tabular}{|c|c|c|c|c|c|c|c|c|}
\hline & \multicolumn{7}{|c|}{ Buyers (in thousand $\left.\mathrm{m}^{3}\right)^{a}$} & \multirow{2}{*}{ Total \% } \\
\hline & Very large & Large & Medium & Small & Very small & Non-identified ${ }^{b}$ & Total & \\
\hline Industry & 659.7 & 68.6 & 221.1 & 1.5 & 0.1 & 0 & 950.9 & 46.9 \\
\hline Depot & 15 & 205.4 & 150.5 & 197 & 1.2 & 0 & 391.7 & 19.3 \\
\hline No destination & 0 & 0 & 0 & 0 & 0 & 291.8 & 291.8 & 14.4 \\
\hline Sawmill & 0 & 72.1 & 72.3 & 6.8 & 0.4 & 0 & 151.6 & 7.5 \\
\hline Transport & 13.5 & 6.2 & 20.9 & 4.2 & 0.4 & 0 & 45.2 & 2.2 \\
\hline Carpentry & 0 & 4.9 & 27.5 & 8.9 & 0.5 & 0 & 41.8 & 2.1 \\
\hline Furniture store & 0 & 5.8 & 22.9 & 9.2 & 0.4 & 0 & 38.4 & 1.9 \\
\hline Hardware store & 0 & 8.1 & 16.7 & 7.7 & 0.3 & 0 & 32.8 & 1.6 \\
\hline Services & 15.9 & 5.5 & 6.6 & 1.9 & 0.4 & 0 & 30.2 & 1.5 \\
\hline Not declared & 0 & 4.4 & 4.5 & 2.2 & 0.4 & 0 & 11.5 & 0.6 \\
\hline Agricultural & 0 & 4.7 & 3.7 & 2.4 & 0.6 & 0 & 11.3 & 0.6 \\
\hline Other $^{d}$ & 0 & 7.4 & 14.5 & 5.7 & 0.8 & 0 & 28.6 & 1.4 \\
\hline Total & 704 & 393,1 & 561,4 & 70.1 & 5.4 & 291.8 & 2025.8 & 100 \\
\hline
\end{tabular}

Note: a) These groups have been classified according to the annual transported volume. Very large: more than 12,000 m3/year; large: 1200,1 to $12,000 \mathrm{~m}^{3} /$ year; medium: 120.1 to $1200 \mathrm{~m}^{3} /$ year; small: 12.1 to $120 \mathrm{~m}^{3} /$ year; very small: 0.1 to $12 \mathrm{~m}^{3} /$ year, b) it corresponds to transport permits that do not specify RUC of final destination, c) not declared means that the executor has not declared the trade name or main business activity in SRI, d) it includes the establishments in which the registration of the trade name or the main commercial activity is not related to forestry, etc.).

Source: Own elaboration based on SAF, Ministry of Environment of Ecuador (2011). 


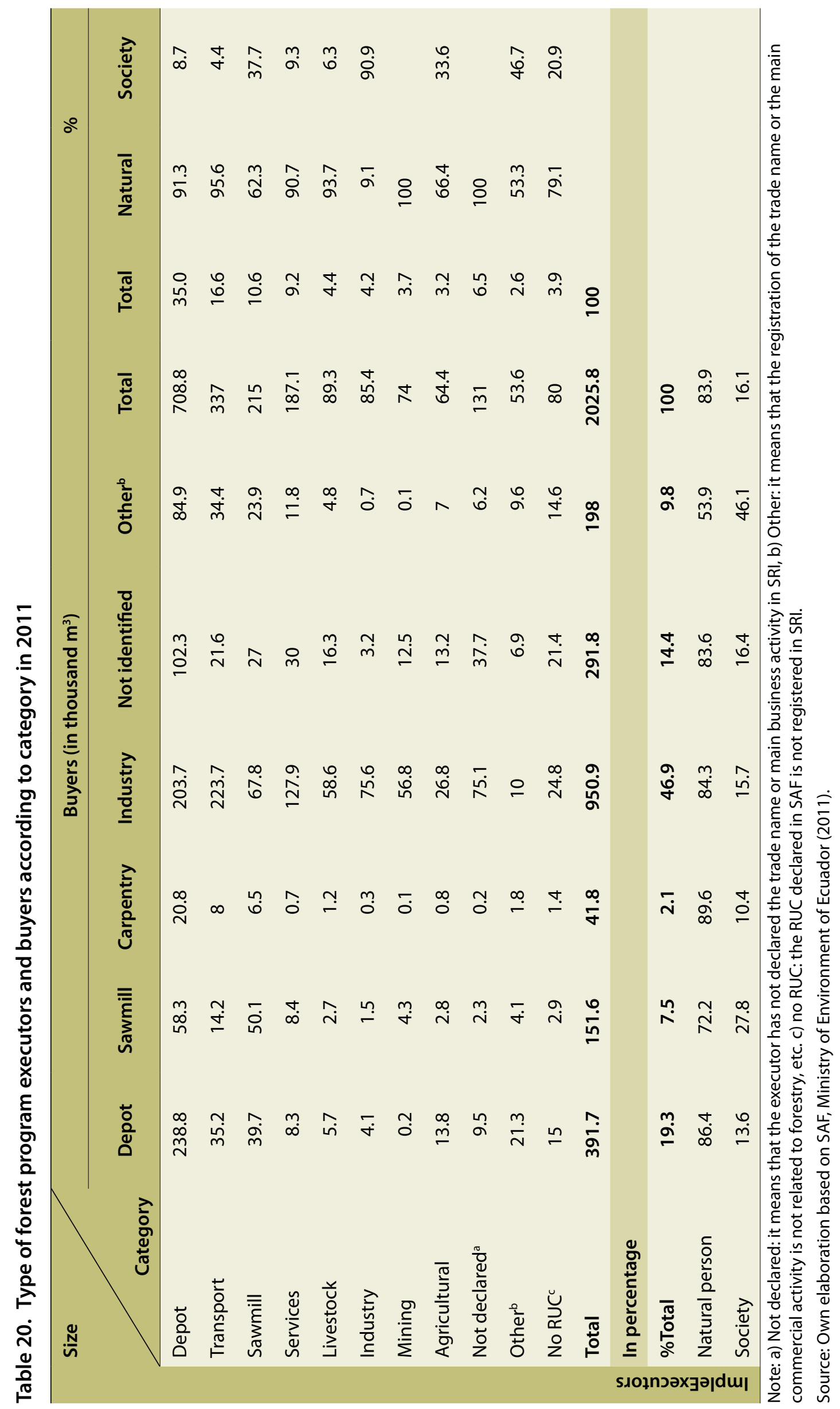




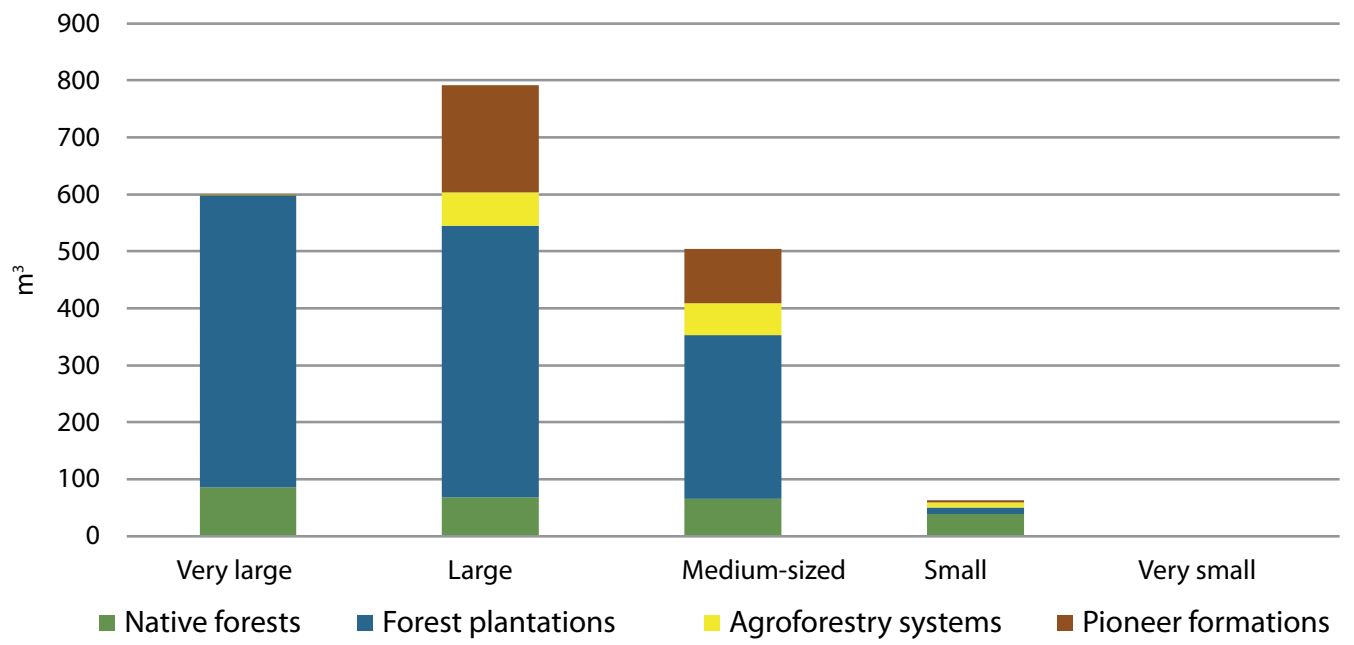

Figure 7. Transported volume by executor size and forest formation (thousand $\mathrm{m} 3$ ). Personal compilation based on SAF, Ministry of Environment of Ecuador (2011).

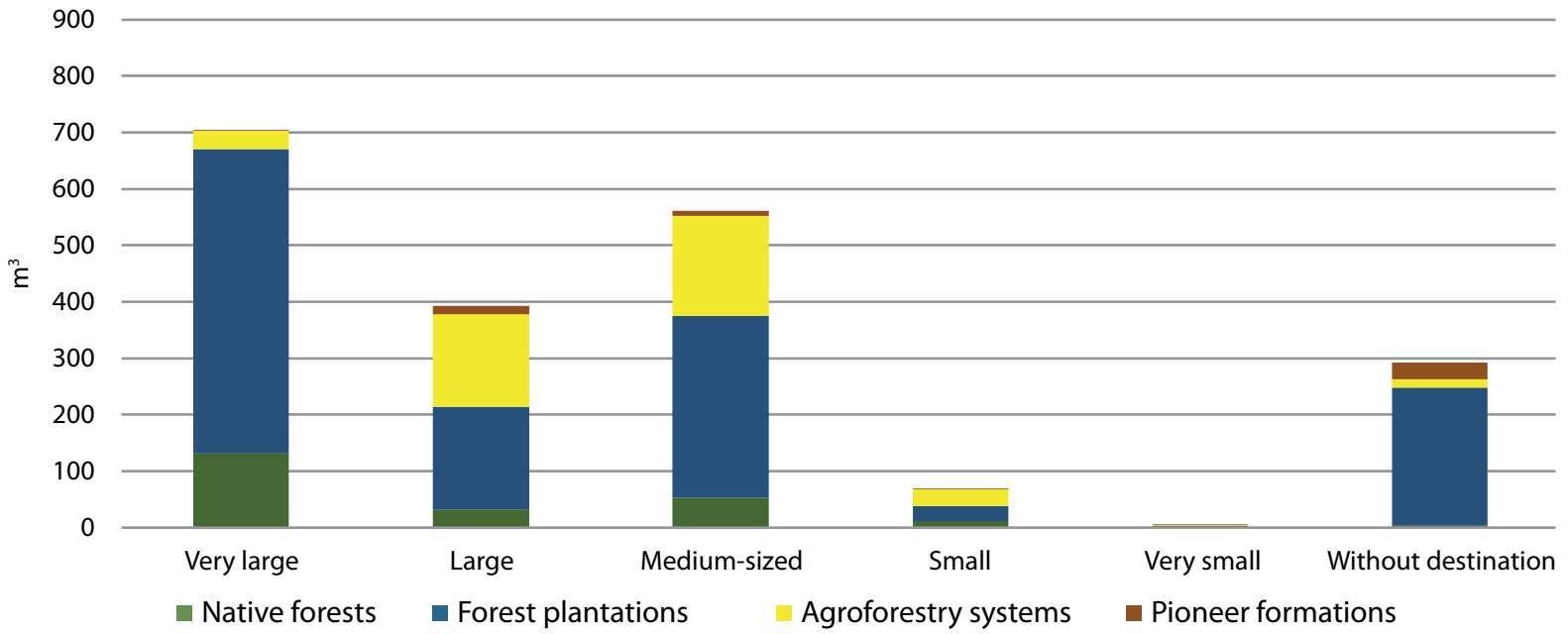

Figure 8. Transported volume by buyer size and forest formation (thousand $\mathrm{m}^{3}$ ). Personal compilation based on SAF, Ministry of the Environment of Ecuador (2011).

Unlike the situation at the national level, where industrial facilities consume the largest portion of mobilized timber, in the Amazon it is depots and sawmills that buy $44 \%$ of the timber produced in the region, which is also marketed at industrial establishments, closing the marketing circle (Table 22). Timber originating in the Amazon is mainly used in the furniture and construction industries. Most of it comes from small-scale harvesting operations in native forests, as discussed above, chuncho and laurel being the most valued species (see also Vásquez 2011). At the national level, however, the most widely sold species come from forest plantations, mainly eucalyptus, pine tree and teak. This suggests that the species from native Amazon forests are important for some urban market segments. For the Ministry of Environment of Ecuador (2011), native forest supplies sawn timber for furniture and construction industries in major cities, including Quito, Guayaquil, Cuenca, Ambato, and Manta.

An important aspect is the fact that the most important group of timber buyers from the Amazon are "medium-sized" buyers, who purchase around $45 \%$ of the timber supplied by executors 


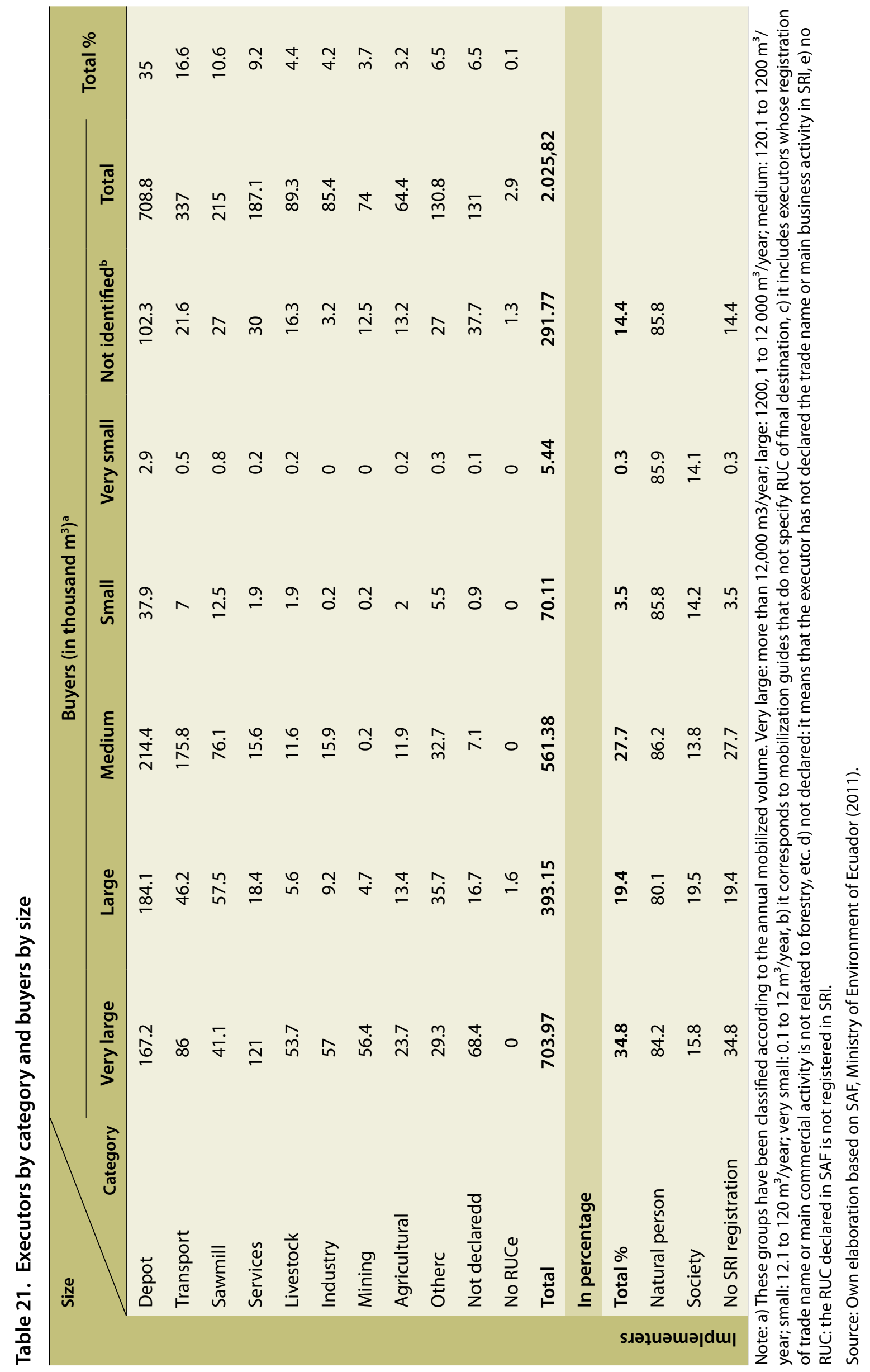



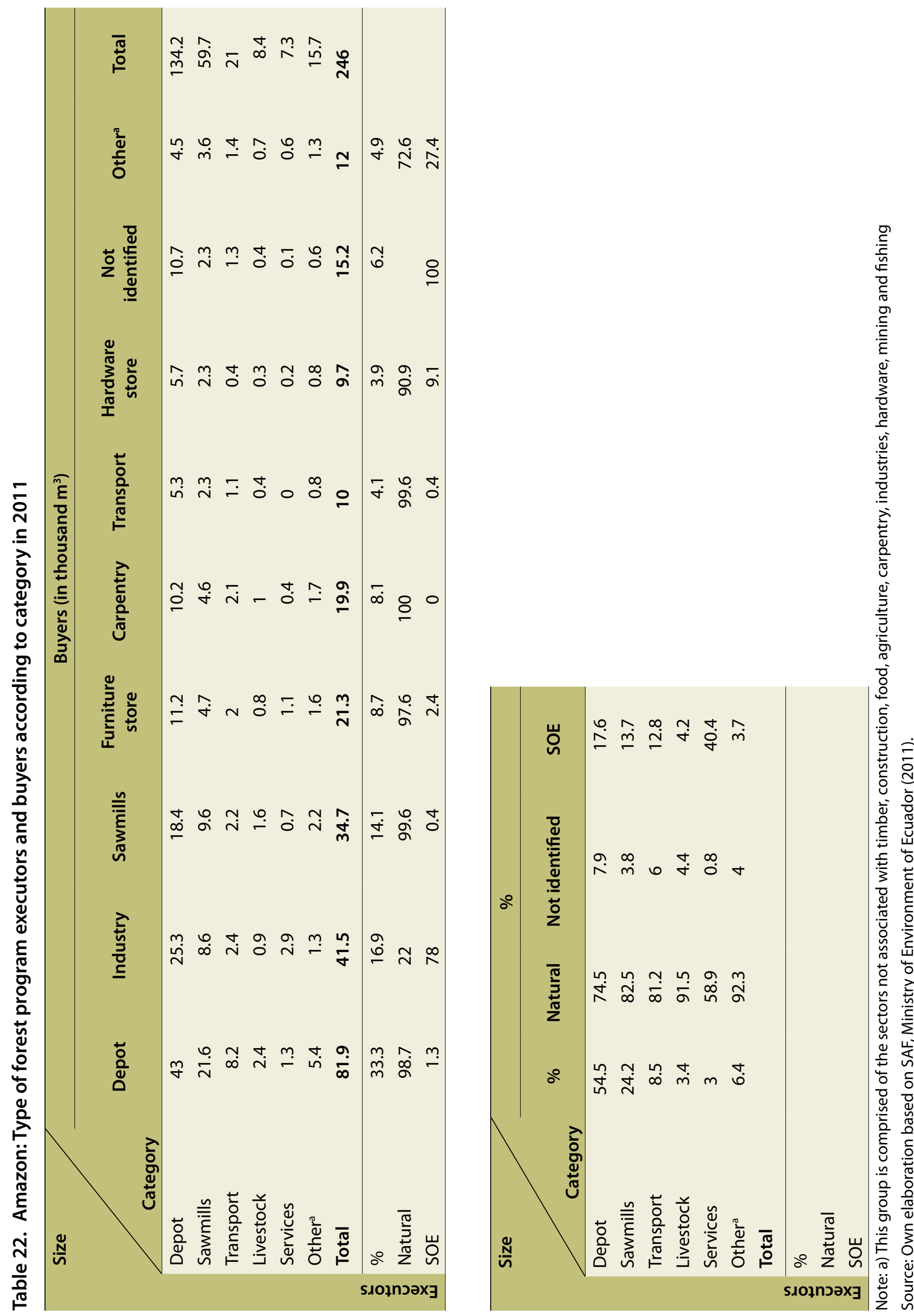
Table 23. Amazon: Executors by category and buyers by size

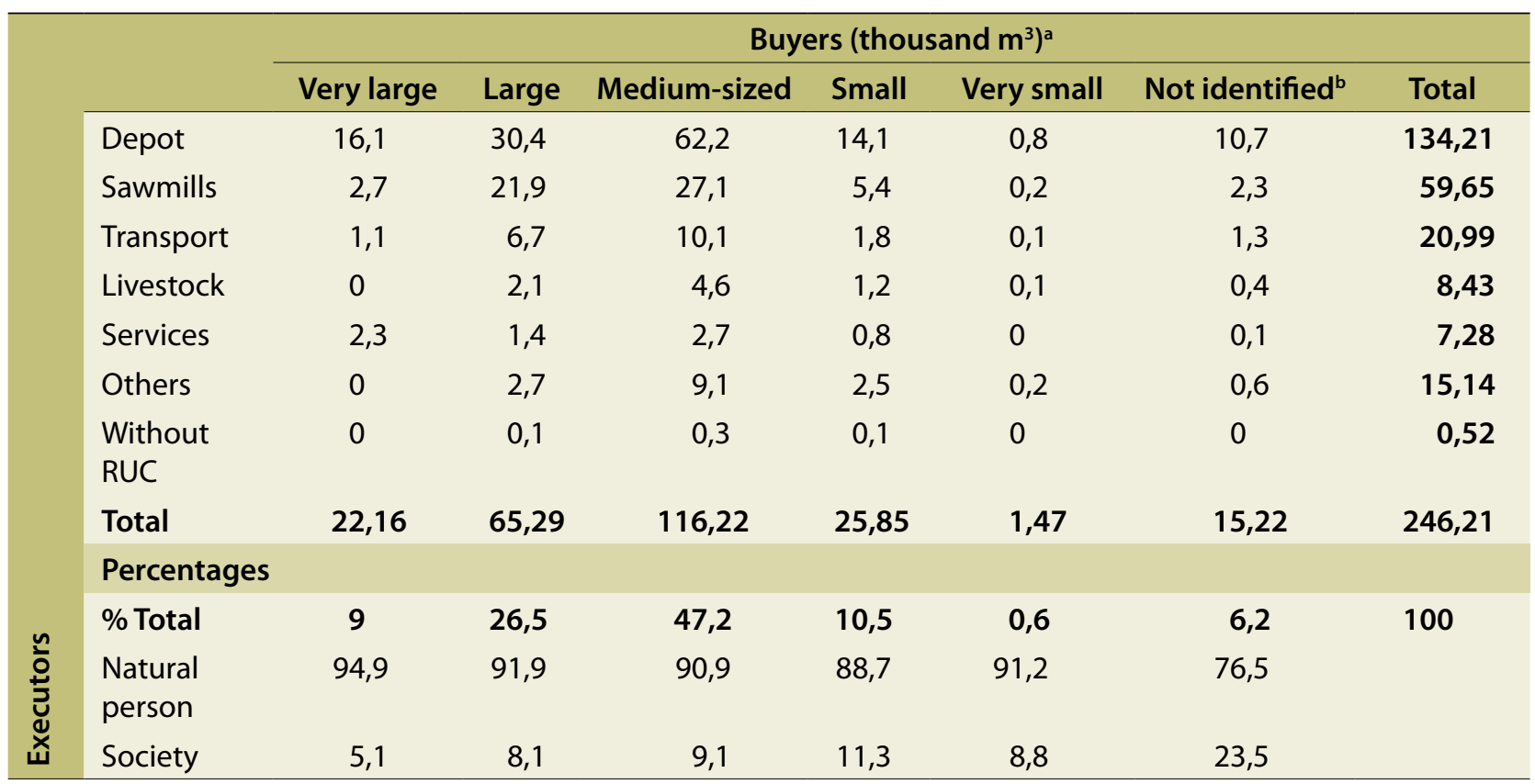

Note: a). These groups have been classified by the volume of annual mobilization. Very large: more than $12000 \mathrm{~m}^{3} / \mathrm{year}$, large: 1200,1-12 $000 \mathrm{~m}^{3} /$ year, medium-sized: 120,1-1200 $\mathrm{m}^{3} /$ year, small: $12,1-120 \mathrm{~m}^{3} /$ year, and very small: $0,1-12 \mathrm{~m}^{3} /$ year; $\mathrm{b}$ ) Corresponds to transport permits that do not specify the RUC of final destination.

Source: Own elaboration based on data from SAF, Ministry of Environment of Ecuador (2011).

operating in the region, amounting to $74 \%$ together with the "large" group. These buyers would be connected with executors registered as depots and sawmills, who supply most of the timber that originates in the Amazon. These medium-sized and large buyers are usually the ones that obtain the orders that are later requested from a large network of depots and sawmills located in intermediary urban centers in this region (Table 23). Depots, sawmills and transporters purchase timber that ends up especially in the industry, although the main destinations declared at SAF are other depots and/ or sawmills.

\subsection{Timber establishments in four cities $^{23}$}

Depots are the establishment with the largest timber movement. In order to better understand the composition of the sector, an inventory of timber storage and processing establishments in the urban centers of Quito, Cuenca, Tena,

23 The information in this section has been collected by Maritza Cifuentes (Quito), Francisco Zaruma Pinguil (Cuenca), Rolando López (Tena), and John Arruti (Coca). and Coca was made from December 2011 to March 2012. Overall, 189 establishments were interviewed, which were classified as depots, sawmills, carpentries, and mixed facilities. These cities were given priority since they were part of the circuits of timber transport in the areas under study.

Regarding suppliers, the establishments in the cities of Quito and Cuenca receive timber mainly from intermediaries (Figure 9), while in Tena and Coca smallholders and indigenous communities (apart from intermediaries) have an important role in the provision, which means that smallholders or the communities sell directly to establishments. In most of the cases, intermediaries are in charge of transport from forests to establishments.

Marketing in Cuenca and Quito probably involves several intermediation actors since, as shown in Table 21, it is depots that sell to other depots and to the industry. According to Terán (2012), depots buy and sell timber from different suppliers, but an important share is ultimately intended for the industry. This would mean that there is some clustering in some companies, as suggested by Southgate et. al., 2000 and Sierra, 2001. 


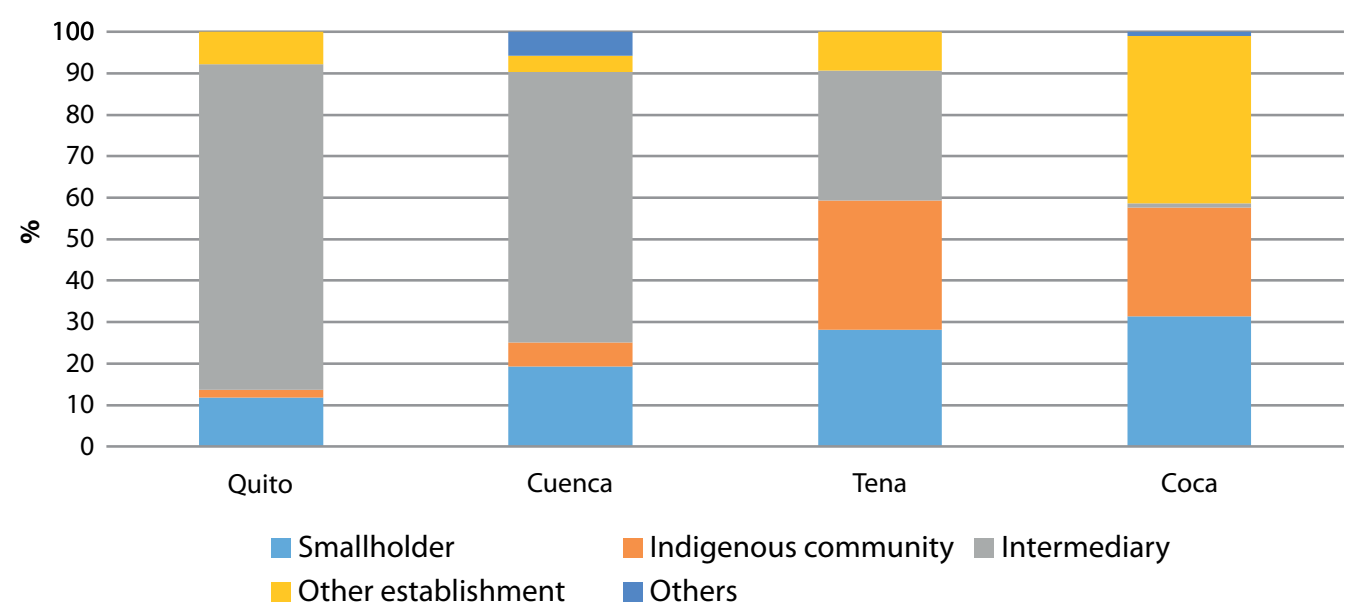

Figure 9. Main suppliers of timber of the interviewed establishments. Personal compilation based on interviews carried out between January and March 2012.

Regarding final timber destination, Quito and Cuenca facilities show that the largest buyers are the carpentry and construction sectors, while Tena and Coca sell more to final consumers in the same district (Figure 10). The main recognized destination for timber from the Amazon was Quito with 82\%, as shown in Map 4. Moreover, according to the establishments interviewed, the city of Cuenca receives $18 \%$ of the timber coming from the Amazon and $82 \%$ from the Coast and the Highlands.

In Tena and Coca, the establishments buy more timber for drying and subsequent marketing, and a smaller portion is intended for the local construction market. In Quito and Cuenca, it goes to the construction and furniture markets as was previously stated.

The main marketed species in Quito and Cuenca are used in construction, like eucalyptus, and furniture making, like chuncho (Cedrelinga cateniformis), laurel (Cordia alliodora) and colorado (Guarea sp.); these species are the same as those in Table 15 for species harvested in the Amazon. Regarding Tena, the main species present in the establishments were yunyún (Terminalia amazonica), laurel (Cordia alliodora) and doncel

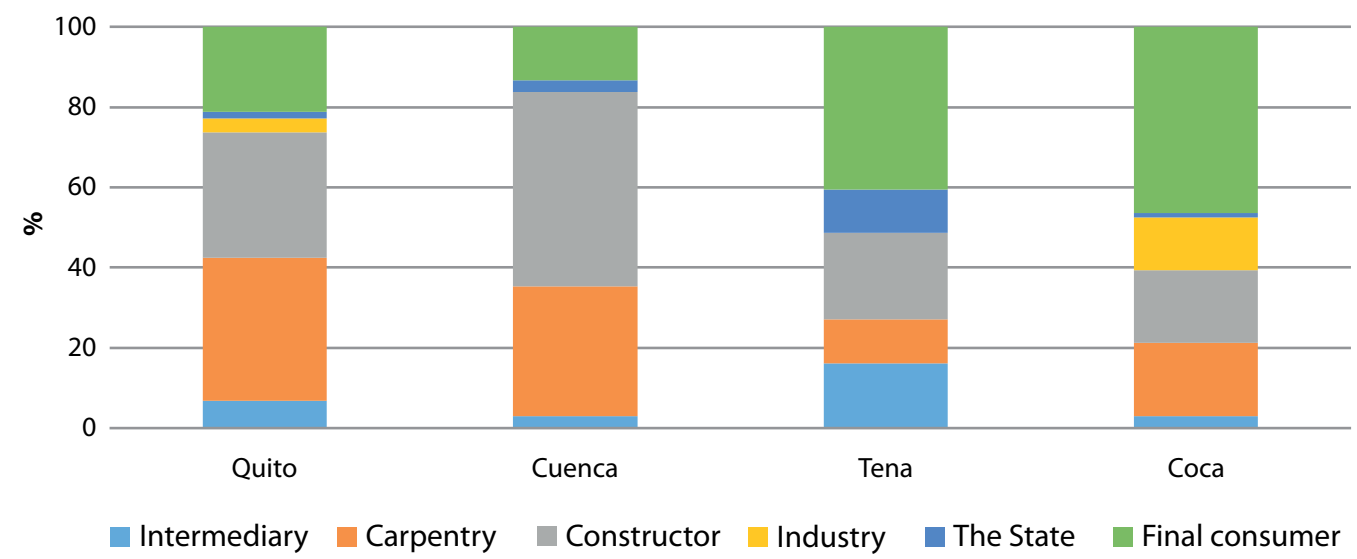

Figure 10. Main buyers of timber of the interviewed establishments. Personal compilation based on interviews carried out between January and March 2012. 
(Otoba spp.). In Coca, the main species are chuncho (Cedrelinga cateniformis) and arenillo (Erisma uncinatum).

In timber marketing and transport there are some gaps that were found during the research on the role of companies in timber storage. Data from five companies, divided into small, medium-sized and large, were collected to form a more detailed picture of timber buyers. The data compared were obtained from SAF and SRI databases. The results are shown in Table 24, which indicates that the transported volume registered under SAF is smaller than the processed volume.

Table 24. Comparison of purchase and processing volumes

\begin{tabular}{lllccc}
\hline Company & Production line & SRI Category & $\begin{array}{c}\text { Purchase } \\
\text { volume }\left(\mathrm{m}^{3}\right)\end{array}$ & $\begin{array}{c}\text { Processing } \\
\text { volume }\left(\mathrm{m}^{3}\right)\end{array}$ & $\begin{array}{c}\text { Negative } \\
\text { difference }\end{array}$ \\
\hline 1 & Floors & Industrial & 126.5 & 166 & 39.5 \\
2 & Doors, windows & Industrial & 906.2 & 1440 & 533.8 \\
3 & Doors, windows & Industrial & 1028 & 840 & \\
4 & Floors & Industrial & 40 & 160 & 120 \\
5 & Furniture & Industrial & 134.4 & 800 & 665.6 \\
\hline
\end{tabular}

Source: Own elaboration based on interviews conducted from January to March 2012 and SAF/SRI data base. 


\title{
Timber harvesting by smallholders in Napo and Orellana
}

\author{
Aymé Muzo, Filippo del Gato, Pablo Pacheco, and Bolier Torres
}

Forest resources, particularly timber, contribute significantly to income generation for small farmers (Angelsen, A. et. al., 2001). Studies on natural resources and livelihoods have paid more attention to the decisions that contribute to shape land use in smallholdings, with special emphasis on forest conversion to agricultural uses, rather than to understanding the decisions that influence on forest management (Southgate, et al., 1991; Bilsborrow, et al., 2004). This chapter analyzes the factors that explain the use of forest resources, especially timber, and their contribution to incomes of small farmers' households located in the provinces of Napo and Orellana in the Ecuadorian Amazon.

The analysis here is centered on the following questions:

- Which are the main features of smallholders, colonists and indigenous peoples that influence their timber harvesting strategies and income?

- What is the importance of timber-derived income for the livelihoods of smallholders, both colonists and indigenous peoples?

- Which factors explain variation in income from timber sales?

Smallholders' decision to sell timber from their forests depends both on endogenous factors related to household characteristics and their access to production resources and on exogenous factors related to the economic and institutional context. Among the first is the availability of physical and financial assets (Barret, 2008), as well as access to information to decide on the use of resources in different production activities (Wollni, 2006) that have an impact on land and forest management (De Sherbinin et. al., 2008). Among the second are timber market conditions characterized by asymmetric relations of information and power between different agents, which tend to affect their relation with the markets (Pacheco, 2012), as well as other decisions for management of their resources (Key, et al., 2000). Both information asymmetries and the requirements in forestry standards not only influence decisions on forest use, but also lead to additional transaction costs (Pacheco et al. 2008).

This analysis is based on primary information gathered at the level of smallholdings in the provinces of Napo and Orellana. The canton of Tena was selected in Napo; 126 families were interviewed (77 colonists and 49 Kichwa indigenous families) distributed into 12 communities (see again Map 1). This canton was selected because a considerable number of smallholders who are settled in this area work with timber harvesting. In Orellana province, 120 families were interviewed ( 48 colonists, 46 Kichwa indigenous families and 26 Shuar indigenous families) distributed into nine communities in the municipality of Francisco de Orellana. This municipality has the largest volume of timber harvesting in the native forests of the province.

The selection of the households to be interviewed was based on a sampling in two stages: the first one for the selection of the communities and the second for the selection of the households in each selected community. The first stage used the intentional sampling method to select communities that offered variety in the following characteristics: 1) ethnic origin of smallholders including colonists and indigenous communities (Kichwas and Shuars), 2) distance to the nearest accessible road throughout the year, 3) size of communities including large communities (more than 40 households) and small communities (less than 40 households). The household selection was made with a simple random sample. For this end, a census of all the households was elaborated based on interviews with local leaders, and then households were randomly chosen to be 
Table 25. Characteristics of colonist and Kichwa households

\begin{tabular}{|c|c|c|}
\hline Variables & Colonists & Kichwas \\
\hline Origin & $\begin{array}{l}85 \% \text { were not born in Napo and come mainly } \\
\text { from the provinces of Bolivar and Loja. }\end{array}$ & $\begin{array}{l}53 \% \text { were not born in the community } \\
\text { and come from other communities in } \\
\text { the province of Napo. }\end{array}$ \\
\hline $\begin{array}{l}\text { Number of } \\
\text { household members }\end{array}$ & 4 adults and 1 child & 6 adults and 3 children \\
\hline $\begin{array}{l}\text { Average age of head } \\
\text { of household }\end{array}$ & 53 & 43 \\
\hline \multirow[t]{2}{*}{ Education } & \multicolumn{2}{|c|}{$\begin{array}{l}\text { Formal education levels are low among heads of households. There is no difference } \\
\text { between colonist and Kichwa households. The illiteracy rate is 5\%, while } 81 \% \text { of all heads } \\
\text { of household have completed primary school. }\end{array}$} \\
\hline & \multicolumn{2}{|c|}{$\begin{array}{l}\text { The other members (not heads of household) of colonist households show better primary } \\
\text { and secondary education rates than the other members of Kichwa families. }\end{array}$} \\
\hline Type of tenure: & Individual, $83 \%$ have a property register or title & $\begin{array}{l}\text { Community, } 49 \% \text { have a property } \\
\text { register or title }\end{array}$ \\
\hline
\end{tabular}

Source: Own elaboration based on a household survey conducted between August and September 2012.

interviewed by means of a raffle in the presence of one or more leaders of the community. A constant fraction sampling was used to ensure that the sample did not have proportionately more households from small communities than large communities.

Household samplings were made between January and September 2012 in Napo and Orellana. The questionnaire was changed based on the prototype developed by CIFOR's PEN Project ${ }^{24}$. The questionnaire collects information on the demographic characteristics of the household and education (human capital), housing, land and other physical assets (physical capital) and land use and forest status (natural capital). Besides, information on income related to harvesting of timber and non-timber forest resources was collected as well as other household income, including income within and outside smallholdings. Questions also focused on views on current forestry standards.

For an analysis of smallholders' strategies, the case of Napo and Orellana will be analyzed separately, as data collection was made in different periods, and because we want to show the differences between the two provinces.

24 Available at http://www.cifor.org/fileadmin/fileupload/ PEN/pubs/pdf_files/Cuestionario_Prototipo_PEN_ Espanol-version4.pdf

\subsection{The case of Napo: Analysis of smallholders' strategies}

\subsubsection{Characteristics of households}

The main differences between the households of colonists and Kichwas are associated with the origin, the age of the head of the household and the number of members in the household. Table 25 presents the characteristics of these two groups. It shows that the number of household members is larger for Kichwas, the heads of households of Kichwa families are younger, and the level of education of adult Kichwas is lower than in colonist households. Regarding land tenure, colonists own only private properties and Kichwas have mainly community-type properties. Colonist households decide on land use and have property titles in most of their smallholdings.

Instead, Kichwa households have collective tenure titles and the community assembly assigns access to lands, and some regulations must be respected. For instance, in some communities, sale of timber must be discussed with the community president, unlike for colonists' private properties, where each family decides what to do with timber.

\subsubsection{Land use and production systems}

Both groups develop relatively diversified production systems within smallholdings, while forests take up the largest area of the plot in both groups. Colonists' households in Napo have a larger land area; however, the forest area is rather 
similar to that of Kichwa households. This is due to the fact that cultivated areas, including perennial and annual crops and pastures, are larger in colonists' plots (10 hectares) than in Kichwa plots ( 4 hectares), particularly the areas planted with perennial crops and pastures. Areas with pastures are four times larger in colonists' than in Kichwas' lands. Both colonists and Kichwas harvest cocoa and coffee, in addition to guayusa in Kichwa households, all intended for the market. Nevertheless, colonists' lands with perennial crops are twice as large as those of the Kichwas'. In the area planted with annual crops, secondary forests, realce (regenerated secondary forests), and orchards in smallholdings is similar in the two groups (Table 26).

Of the overall figure of colonists and Kichwas interviewed, $57 \%$ of the households cleared 2.8 hectares, on average, in their plots in the 2006-2012 period, accounting for 0.47 hectares per year. Slightly more than half of those surveyed $(52 \%)$ have cleared native forests, $18 \%$ in secondary forests and $30 \%$ in rastrojos (fallows) or regenerated secondary forests. This indicates that clearing does not only occur in native forests but also in secondary and regenerated secondary forests, so it is easier for smallholders to work in a forest that has already been harvested if their purpose is to use it for crops, since less labor will be used for clearing. Both colonists and Kichwas have cleared a similar land area in the above period. However, it is important to mention that the clearing frequency is higher in Kichwa households although the area cleared per operation is smaller. The cleared area is generally used to grow market crops (corn and cocoa) and pastures to a lesser extent. Clearing occurs in lands which are more suitable for crops, near the household, $1.2 \mathrm{~km}$ away on average. Kichwa households also say that deforested lands are located in the only areas that were available due to land fragmentation among household members.

A total of $61 \%$ of forest lands converted to agricultural uses were not intervened for timber extraction before clearing during the above period. Out of 71 households that cleared forest in their smallholdings, 49 households had species demanded by the market in their lands; however, only 28 of them sold the timber before or during clearing and the rest did not do so. This is because there were no valuable species in the smallholding or the timber value was unknown. In the case of Kichwa families, the lack of access roads and the excessive transport distance from the forest to the point of sale can be added to the previous factors. That is, only $38 \%$ of households have obtained timber for sale as a by-product of clearing aimed at expanding their cultivation areas (Table 27).

Table 26. Land use (in hectares) in colonist and Kichwa plots

\begin{tabular}{lcccc} 
& \multicolumn{2}{c}{ Colonists } & \multicolumn{2}{c}{ Kichwas } \\
\cline { 2 - 5 } & Average & Standard deviation & Average & Standard deviation \\
\hline Native forest $^{\mathrm{a}}$ & 14.27 & 17.52 & 9.86 & 13.31 \\
Secondary forest $^{\mathrm{b}}$ & 0.61 & 2.34 & 1.56 & 4 \\
Regenerated secondary forest $^{\mathrm{c}}$ & 4.16 & 5.97 & 3.07 & 5.78 \\
Pastures & 5.90 & 9.18 & 1.36 & 2.63 \\
Annual crops $^{\mathrm{d}}$ & 1.22 & 1.61 & 1.10 & 1.87 \\
Perennial crops $^{\mathrm{e}}$ & 3.13 & 3.58 & 1.67 & 1.57 \\
Farm $^{\mathrm{f}}$ & 0.15 & 0.43 & 0.19 & 0.46 \\
Other $^{\mathrm{g}}$ & 0.94 & 2.09 & 0.60 & 1.36 \\
Total & $\mathbf{3 0 . 3 8}$ & $\mathbf{2 3 . 0 3}$ & $\mathbf{1 9 . 4 1}$ & $\mathbf{1 7 . 2 6}$ \\
\hline
\end{tabular}

Note: a) It refers to undisturbed forests, b) These are naturally regenerating forests, c) It refers to a young secondary forest that has regenerated naturally after being disturbed by human activities, d) It includes corn, banana, cassava and orange, e) It includes cocoa, coffee and guayusa, f) It is the area destined for household consumption and it includes, for example, cassava and banana, g) These are areas which cannot be cultivated, i.e. swamp and rocky areas.

Source: Own elaboration based on a household survey conducted between August and September 2012. 
Table 27. Deforestation in Kichwa and colonist plots for 2006-2012

\begin{tabular}{lccr}
\hline & Colonist & Kichwa & Total \\
\hline Total no. of plots & 48 & 76 & 124 \\
No. of deforested plots & 24 & 47 & 71 \\
$\begin{array}{l}\text { No. of clearing } \\
\text { activities with previous }\end{array}$ & 9 & 19 & 28 \\
timber extraction & & & \\
$\begin{array}{l}\text { Main timber } \\
\text { destination }\end{array}$ & Sale & Sale & \\
\hline
\end{tabular}

Source: Own elaboration based on a household survey conducted between August and September 2012.

\subsubsection{Total and forest income}

Households have quite diversified income: from agricultural crops, government transfers (Human Development Bond, Bono de Desarrollo Humano $)^{25}$, timber harvesting, and salary incomes from outside smallholdings (Table 28). Colonists' households have higher incomes than Kichwas, the main income coming from forest production and wage labor. The main sources of income in Kichwa households are wage labor and human development bonuses. Salary income comes mainly from jobs outside smallholdings, especially as chainsaw operators. It is worth highlighting that wage labor outside smallholdings and the sale of other products help relax credit constraints, providing more liquidity to smallholders. The Human Development Subsidy is a direct monthly income for smallholders, which also helps improve household liquidity.

Forest income is an important source of income for rural families in the province of Napo, with remarkable importance of profits from the sale of timber, especially for colonist families. The

Table 28. Kichwa and colonist income for August 2011-September 2012

\begin{tabular}{|c|c|c|c|c|c|c|c|c|}
\hline \multirow{3}{*}{ Source of income } & \multicolumn{6}{|c|}{ Average income } & \multicolumn{2}{|c|}{$\begin{array}{l}\text { No. of households } \\
\text { receiving income from } \\
\text { these activities }\end{array}$} \\
\hline & \multicolumn{2}{|c|}{ Colonists $(n=47)$} & \multicolumn{2}{|c|}{ Kichwas $(n=76)$} & \multicolumn{2}{|c|}{ Total $(n=123)$} & \multirow{2}{*}{ Colonists } & \multirow{2}{*}{ Kichwas } \\
\hline & USD & $\%$ & USD & $\%$ & USD & $\%$ & & \\
\hline Wage labor ${ }^{a * *}$ & 1064 & 33 & 813 & 43 & 909 & 38 & 24 & 52 \\
\hline Sale of forest products ${ }^{b^{* *}}$ & 1019 & 31 & 210 & 11 & 519 & 22 & 30 & 54 \\
\hline Human Development Subsidy ${ }^{c}$ & 458 & 14 & 437 & 23 & 445 & 18 & 36 & 66 \\
\hline Sale of agricultural production ${ }^{d}$ & 435 & 13 & 322 & 17 & 366 & 15 & 38 & 73 \\
\hline Sale of livestock production ${ }^{e * * *}$ & 218 & 7 & 45 & 2 & 111 & 5 & 21 & 11 \\
\hline Own business $^{f}$ & 121 & 4 & 37 & 2 & 69 & 3 & 7 & 10 \\
\hline Others & 29 & 1 & 10 & 1 & 17 & 1 & 3 & 8 \\
\hline Sale of fish ${ }^{* * *}$ & 0 & 0 & 20 & 1 & 13 & 1 & 0 & 8 \\
\hline Total $* * * i$ & 3259 & 100 & 1884 & 100 & 2410 & 100 & & \\
\hline
\end{tabular}

Note: a) Wage labor includes all labor that is carried out outside the smallholding and that is paid, for example, agricultural labor, sawmilling and labor under fixed contracts, b) Sale of forest products refers to income in cash for the sale of non-timber forest products (NTFP) and income obtained from the government's Forest Partner (Socio Bosque), c) The income from the Human Development Subsidy has been already explained, $d$ ) the income derived from agricultural production refers to the income from the sale of agricultural products, for example, cocoa, corn, coffee, guayusa, etc. e) Livestock income is obtained by the sale of animals or their by-products, for example, cattle, hens and milk, among others, $\mathrm{f}$ ) Income from own business refers to any activity in which the smallholder works on his own, i.e., as his own boss; for example, traders, shop owners, etc. g) Other income refers to income that does not come from any of the above categories, $h$ ) Income from the sale of fish comes from fish mainly harvested in community rivers, i) Independent samples t-test in the differences of income diversification between colonists and Kichwas at $1 \%\left(^{* * *}\right)$ and $5 \%\left({ }^{* *}\right)$ level of significance.

Source: Own elaboration based on a household survey conducted between August and September 2012.

25 It is a program of conditional cash transfer that consists in monthly payments of USD 50 to low-income families. According to Carillo P. and Ponce J. (2008), the transfer is targeted to mothers with children under 16 years of age and elderly or disabled people in order to reduce poverty. It is conditional on mothers' sending their children to school and seeking health care services. contribution of timber earnings to total annual net income is $23 \%$ and $8 \%$ in colonist and Kichwa families respectively from August 2011 to September 2012 (Table 29). In the same period, if only the 63 families that received incomes from timber are considered, the share of timber sales in 
Table 29. Description of forest income from timber and non-timber products for August 2011-September 2012

\begin{tabular}{|c|c|c|c|c|c|c|c|c|}
\hline \multirow{3}{*}{ Forest income } & \multicolumn{6}{|c|}{ Average income } & \multicolumn{2}{|c|}{$\begin{array}{l}\text { No. of households that } \\
\text { obtain income from } \\
\text { these activities }\end{array}$} \\
\hline & \multicolumn{2}{|c|}{ Colonists $(n=47)$} & \multicolumn{2}{|c|}{ Kichwas ( $n=76)$} & \multicolumn{2}{|c|}{ Total $(n=12)$} & \multirow{2}{*}{ Colonists } & \multirow{2}{*}{ Kichwas } \\
\hline & USD & $\%$ & USD & $\%$ & USD & $\%$ & & \\
\hline Total household income & 3259 & 100 & 1884 & 100 & 2.410 & 100 & 47 & 76 \\
\hline \multicolumn{9}{|l|}{ Total forest income $e^{* * *}$} \\
\hline Sale of timber ${ }^{* * *}$ & 764 & 23 & 159 & 8 & 381 & 16 & 24 & 39 \\
\hline $\begin{array}{l}\text { Sale of non-timber forest } \\
\text { product (NTFPs) }\end{array}$ & 78 & 2 & 43 & 2 & 56 & 2 & 7 & 16 \\
\hline Socio Bosque Program ${ }^{b^{* * *}}$ & 90 & 3 & 8 & 4 & 39 & 2 & 3 & 24 \\
\hline
\end{tabular}

Note: a) Independent samples t-test in the differences of income diversification between colonists and Kichwas at $1 \%\left({ }^{* * *}\right)$ level of significance. b) In the case of Kichwa communities, the income is divided among all community members. Payments received by household are lower than those obtained by colonists.

Source: Own elaboration based on a household survey conducted between August and September 2012.

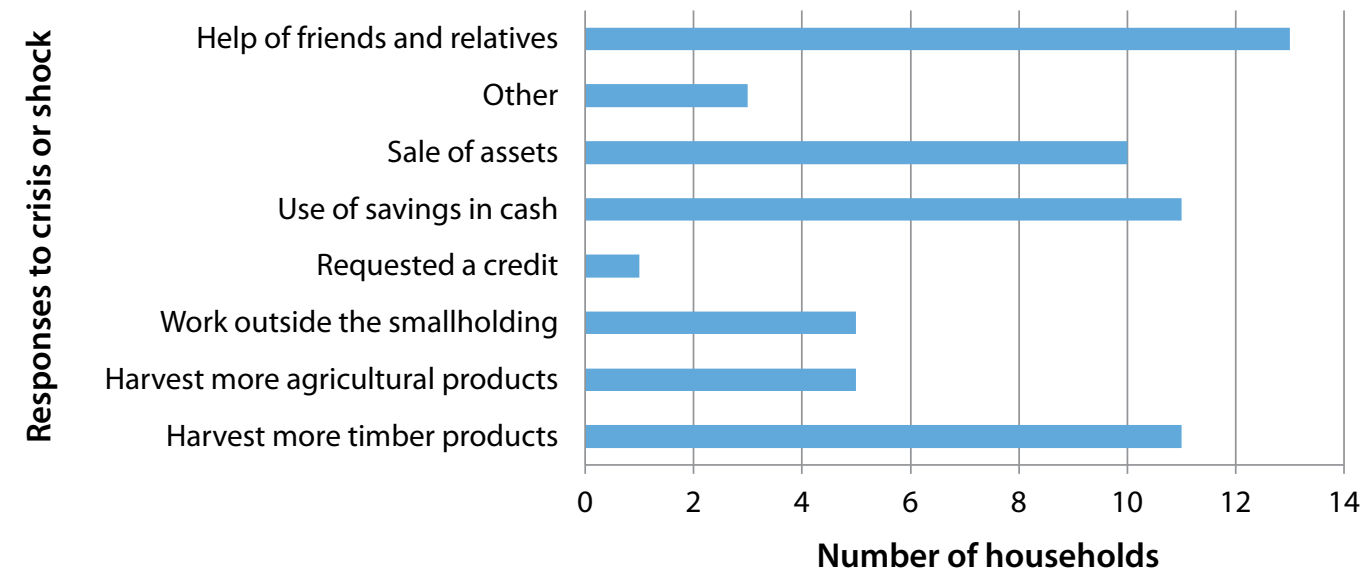

Figure 11. Role of forestry income in family security mechanisms in crisis or contingency situations. Based on a survey to households carried out between August and September 2012.

total income is higher: $46 \%$ in colonist families (3\%-88\% range) and $17 \%$ in Kichwa families (0.5\%-71\% range). It is important to note that salary for work in forestry activities (as chainsaw operators) is not included in forest income. This is mentioned because other authors like Godoy et. al. (2002) do include them in forest income estimates.

Of the households interviewed, 59 respondents (48\%) mentioned some kind of crisis addressed through family loans and aid (22\%), savings $(19 \%)$, harvesting of more timber products $(18 \%)$, sale of cattle and assets (17\%), among others (Figure 11). In Napo province, consequently, forests are not necessarily considered an important resource to overcome families' financial crises. Nevertheless, they play an important role, particularly timber harvesting, in that they help families cover essential expenses-health, education, food, and housing. In this sense, it is considered that the months with the highest timber sales are July and August, i.e. prior to the beginning of school in October in the Amazon. 
In response to the benefits offered by timber to smallholders and the lack of timber species, $51 \%$ of Kichwa households and 33\% of colonist households have planted some trees in their lands, scattered in different parts of their property or as agroforestry associations, for example, mahogany/ahuano (Swietenia macrophylla), cedar (Cedrela odorata), chuncho (Cedrelinga catenaiformes). The main motivation for planting as expressed by interviewees is timber availability for sale and, in a smaller proportion, for domestic uses, such as fuelwood and housing constructions.

\subsection{Differentiated strategies for timber harvesting}

The analysis of smallholders' share in timber harvesting and benefits is not uniform. Thus, a typology considering the following groups has been developed. Group 1 corresponds to the smallholders that harvest on their own; group 2 refers to the smallholders that employ staff ${ }^{26}$; group 3 consists of the smallholders that sell timber to intermediaries, who harvest; and group 4 refers to the smallholders that do not sell timber. Table 30 outlines the main characteristics of these different groups considering household features and access to assets.

The information presented shows that most smallholders harvesting on their own have chainsaws and a bigger number of household members, which provides greater labor availability and makes them different from other groups with fewer members, who need to hire people or find other harvesting strategies. Likewise, plots are bigger than in the group that does not sell timber. Groups 1 and 2 are geographically located closer to a major city and both have the largest amount of assets in goods compared with other groups, which suggests that these groups have some liquidity for timber harvesting, and those in group 2 can afford to hire labor. Group 3 is characterized by having a smaller number of people in the household, heads of household of an older age on average and a geographic location farther from the main city compared with the other groups, which would raise transport costs and might limit timber marketing, so harvesting would be done by intermediaries in charge of the harvesting and marketing process.

26 This group includes smallholders with mixed operations; i.e. harvesting is performed by smallholders with third parties and earnings are divided between the two.

\subsubsection{Timber harvesting strategies}

A total of 79 households interviewed (66\%) sold timber between 2004 and September 2012, while 62 households (50\%) sold timber from August 2011 to September 2012. This analysis refers to the 79 households classified in groups 1 to 3 above. These groups represent $54 \%, 32 \%$ and $14 \%$ of the 79 households that harvested timber from their forests. As it was already mentioned, group 1 is characterized by harvesting mostly with family labor; group 2 by harvesting with hired labor; and group 3 by not harvesting because it is done by the intermediaries.

In order to harvest timber, some households need to ask permission from the community, mainly in Kichwa communities, which own community titles. Timber harvesting is mostly done in the smallholdings, especially in the case of group 3, since it is the intermediary that does the harvesting and needs to request permission from the owners. However, timber has also been harvested from outside smallholdings, although most harvesting was done in the same community in lands belonging to relatives or neighbors (in some cases with mixed use). For instance, two smallholders harvest in the land owned by one of them and reach a mutual agreement on harvesting and its benefits (Table 31).

The three groups do the search and negotiate with the buyer in the same way. Most of the households (56\%) received a purchase order before carrying out the harvesting. Other households (32\%) sought a buyer both before and after harvesting, and the rest $(12 \%)$ waited for the buyers on the road. The search for a buyer and the strategy to leave timber on the road until a buyer arrived reveals smallholders' need to sell and to have some level of certainty that their product will be sold. Timber buyers are usually the intermediaries already identified by smallholders, so $75 \%$ of the smallholders sell their timber to the same buyer. Most smallholders have not received money in advance from buyers, so $85 \%$ has not received money in advance, and those who did received USD 40-1000.

Concerning the negotiation, $68 \%$ of the smallholders responded that the buyer imposes the timber price, $16 \%$ by mutual agreement and $16 \%$ responded they set the price. It is also worth mentioning that when they were asked if the last two transactions were made by the same 
Table 30. Characteristics of the different groups of households according to their timber harvesting strategies

\begin{tabular}{|c|c|c|c|c|}
\hline & \multicolumn{2}{|c|}{$\begin{array}{l}\text { The smallholder carries out the } \\
\text { extraction }\end{array}$} & \multirow{2}{*}{$\begin{array}{l}\text { The intermediary } \\
\text { carries out the } \\
\text { extraction }\end{array}$} & \multirow{2}{*}{$\begin{array}{l}\text { Does not sell } \\
\text { timber }\end{array}$} \\
\hline & On his own & With hired staff & & \\
\hline Number of households & 43 & 25 & 11 & 44 \\
\hline $\begin{array}{l}\text { Ethnic group of head of } \\
\text { household } \mathrm{d}^{\mathrm{w**}}\end{array}$ & $74 \%$ are Kichwa & $60 \%$ are Kichwa & $\begin{array}{l}\text { All of them are } \\
\text { colonists }\end{array}$ & $66 \%$ are Kichwa \\
\hline $\begin{array}{l}\text { Gender of head of } \\
\text { household } d^{b * *}\end{array}$ & \multicolumn{4}{|c|}{$\begin{array}{l}5 \% \text { of heads of household are women (there are no women in the case of } \\
\text { smallholders working on their own) }\end{array}$} \\
\hline $\begin{array}{l}\text { Number of people per } \\
\text { household }\end{array}$ & 7 people & 5 people & 4 people & 5 people \\
\hline $\begin{array}{l}\text { Number of adults per } \\
\text { household }\end{array}$ & \multicolumn{4}{|l|}{3 people } \\
\hline Age of head of household ${ }^{b * * * *}$ & $60 \%$ are under 45 & $60 \%$ are over 45 & $100 \%$ are over 45 & $45 \%$ are over 45 \\
\hline Age of head of household ${ }^{a * * *}$ & 43 years & 50 years & 64 years & 44 years \\
\hline Smallholding size (ha) $)^{\mathrm{a}^{* *}}$ & 24 hectares & 26 hectares & 40 hectares & 18 hectares \\
\hline $\begin{array}{l}\text { Cultivated smallholding size } \\
(\text { (ha) })^{a^{*}}\end{array}$ & 5 hectares & 8 hectares & 11 hectares & 5 hectares \\
\hline $\begin{array}{l}\text { Participation in } \\
\text { organizations }^{\mathrm{b}}\end{array}$ & $\begin{array}{l}60 \% \text { of responden } \\
\text { especially agricult }\end{array}$ & $\begin{array}{l}\text { ts or a member of the ho } \\
\text { ural. }\end{array}$ & usehold take part in & an organization, \\
\hline \multirow[t]{2}{*}{$\begin{array}{l}\text { Work outside the } \\
\text { smallholding }\end{array}$} & \multicolumn{4}{|c|}{$\begin{array}{l}57 \% \text { of respondents labor outside the smallholding and only } 8 \% \text { have an annual } \\
\text { work contract. }\end{array}$} \\
\hline & $\begin{array}{l}33 \% \text { receive } \\
\text { an income as } \\
\text { a chainsaw } \\
\text { operators outside } \\
\text { the smallholding }\end{array}$ & $\begin{array}{l}8 \% \text { receive an } \\
\text { income as a chainsaw } \\
\text { operator outside the } \\
\text { smallholding }\end{array}$ & $\begin{array}{l}\text { Nobody works } \\
\text { as a chainsaw } \\
\text { operator outside } \\
\text { the smallholding }\end{array}$ & $\begin{array}{l}11 \% \text { receive } \\
\text { an income as } \\
\text { a chainsaw } \\
\text { operators } \\
\text { outside the } \\
\text { smallholding }\end{array}$ \\
\hline Have a savings account ${ }^{b}$ & \multicolumn{4}{|c|}{$\begin{array}{l}70 \% \text { of households have no access to a savings account in a bank, cooperative, } \\
\text { association, etc. }\end{array}$} \\
\hline \multicolumn{5}{|l|}{ Assets } \\
\hline Mobile phone $\mathrm{e}^{\mathrm{b}^{* *}}$ & $\begin{array}{l}74 \% \text { have mobile } \\
\text { phone }\end{array}$ & $\begin{array}{l}60 \% \text { have mobile } \\
\text { phone }\end{array}$ & $\begin{array}{l}55 \% \text { have mobile } \\
\text { phone }\end{array}$ & $\begin{array}{l}45 \% \text { have mobile } \\
\text { phone }\end{array}$ \\
\hline Chainsaw $^{b * * *}$ & $\begin{array}{l}77 \% \text { have } \\
\text { chainsaws }\end{array}$ & $24 \%$ have chainsaws & $\begin{array}{l}9 \% \text { have } \\
\text { chainsaws }\end{array}$ & $\begin{array}{l}27 \% \text { have } \\
\text { chainsaws }\end{array}$ \\
\hline Canoe $\mathrm{b}^{\mathrm{b}^{* *}}$ & $35 \%$ have canoes & $16 \%$ have canoes & $\begin{array}{l}\text { They do not have } \\
\text { canoes }\end{array}$ & $16 \%$ have canoes \\
\hline Cattle $\mathrm{b}^{\mathrm{b}^{*}}$ & $21 \%$ have cattle & $36 \%$ have cattle & $55 \%$ have cattle & $18 \%$ have cattle \\
\hline Other assets & \multicolumn{4}{|c|}{$54 \%$ have spray pumps and $30 \%$ have pack animals } \\
\hline Total assets $(\$)^{\mathrm{a}^{* *}}$ & $\begin{array}{l}\text { On average USD } \\
1140\end{array}$ & On average USD 1320 & $\begin{array}{l}\text { On average USD } \\
682\end{array}$ & $\begin{array}{l}\text { On average USD } \\
530\end{array}$ \\
\hline Distance to main town $n^{* * *}$ & 49 miles & 48 miles & 103 miles & 83 miles \\
\hline
\end{tabular}

Note a): it refers to the results of the analysis of variance (ANOVA) on the differences between characteristics of types of use at $1 \%\left(^{* * *}\right), 5 \%\left(^{* *}\right)$ and $10 \%\left({ }^{*}\right)$ level of significance, b) Pearson's Chi-square test ${ }^{\mathrm{b}}$ is significant at $1 \%\left({ }^{* * *}\right), 5 \%\left({ }^{* *}\right)$ and $10 \%(*)$ level of significance.

Source: Own elaboration based on a household survey conducted between August and September 2012. 
Table 31. Harvesting characteristics according to predominant type

\begin{tabular}{|c|c|c|c|c|}
\hline & & \multicolumn{2}{|c|}{$\begin{array}{l}\text { Smallholder conducts the } \\
\text { extraction }\end{array}$} & \multirow{2}{*}{$\begin{array}{l}\text { Intermediary } \\
\text { conducts the } \\
\text { extraction }\end{array}$} \\
\hline & & On his own & With hired staff & \\
\hline \multirow{2}{*}{$\begin{array}{l}\text { Requested permission from the } \\
\text { community }\end{array}$} & Yes & $4(10 \%)$ & $4(17 \%)$ & \\
\hline & No & $38(90 \%)$ & $20(83 \%)$ & $11(100 \%)$ \\
\hline \multirow[t]{2}{*}{ Place of timber extraction } & Own smallholding & $31(72 \%)$ & $21(84 \%)$ & $11(100 \%)$ \\
\hline & Outside the smallholding & $12(28 \%)$ & $4(16 \%)$ & \\
\hline \multirow[t]{2}{*}{ Place of sale of timber } & In the community & $35(85 \%)$ & $18(72 \%)$ & $7(100 \%)$ \\
\hline & Outside the community & $6(15 \%)$ & $7(18 \%)$ & \\
\hline
\end{tabular}

Source: Own elaboration based on a household survey conducted between August and September 2012.

buyer or a different one, $75 \%$ of the smallholders said that it was the same buyer, especially the category of smallholders that harvest on their own. Information about timber prices in the national market is limited; however, $64 \%$ of the smallholders know the price paid by the different buyers in the local market. Information about prices is obtained by buyers and by a neighbor or relative $-45 \%$ and $50 \%$ of the cases, respectively.

A total of $82 \%$ of the households sold the timber in their own community; these smallholders traveled $1.8 \mathrm{~km}$ on average to the point of sale, while the smallholders that sold outside the community traveled $10.6 \mathrm{~km}$, on average. Smallholders that sell timber within the community usually require animal transport, due to the distance; while smallholders that sell outside the community resort to river and road transport, among others.

Table 32 describes the formality condition of harvesting operations (with or without a program) and the number of products sold by product type. Group 1 is characterized by selling most of its timber without a harvesting program (84\%), selling the smallest amount of timber both in number of trees and in volume and at a sale frequency of twice a year compared with the other groups. Group 2 sells 76\% without a harvesting program; the amount sold in $\mathrm{m}^{3}$ is between the other groups, and the sale frequency is three times a year, i.e. the same as for group 3. The latter is characterized by selling a larger volume of timber with a harvesting program $(64 \%)$ and with a sale frequency of three times a year.
Most timber is sold as sawn timber; just 3\% is sold as standing trees within group 3. Table 33 shows that most Kichwas households (87\%) sell sawn timber without a harvesting program unlike colonist households (55\%). One of the reasons that could account for this tendency is the amount sold by each group, for instance, Kichwas sell, on average, a smaller amount of sawn timber than colonists, so developing a harvesting program would not compensate them; besides, most households lack a property title, which is an indispensable requisite for a harvesting program. The informality is reflected in almost all the harvesting strategies, but less so in group 3, where intermediaries do all the harvesting.

If smallholders decide to harvest formally, the volume of timber sold in $\mathrm{m}^{3}$ is on average three times higher than if they decide to sell their timber informally (Table 33). Group 2, which uses the informal strategy where hired labor is used, is characterized by a remarkably clear difference between the amount harvested by colonists and Kichwas. That is to say, the group of Kichwas has the resources for harvesting, whether because they partner up with other smallholders or because they have their own resources; however, resources may not be high enough compared with those of the colonists which allow for larger-scale forest harvesting.

\subsubsection{Costs and benefits of harvesting}

The analysis of smallholders' net income (gross income minus costs) considers only the last 12 months from August 2011 to September 2012. The main items included in harvesting costs are supplies, spare parts, salaries, animal rental, 
Table 32. Characteristics of the sale of timber according to the form of harvesting

\begin{tabular}{|c|c|c|c|c|c|}
\hline & & \multicolumn{2}{|c|}{$\begin{array}{c}\text { Smallholder conducts the } \\
\text { extraction }\end{array}$} & \multirow{2}{*}{$\begin{array}{l}\text { Intermediary } \\
\text { conducts the } \\
\text { extraction }\end{array}$} & \multirow{2}{*}{ Total } \\
\hline & & On his own & With hired staff & & \\
\hline \multicolumn{6}{|c|}{ August 2011-September 2012} \\
\hline Without a program $\mathrm{b}^{* * *}$ & No. of households & 27 & 16 & 2 & 45 \\
\hline With a program ${ }^{b^{* * *}}$ & & $6(18 \%)$ & $5(24 \%)$ & $7(78 \%)$ & 18 \\
\hline \multirow{2}{*}{$\begin{array}{l}\text { Timber sold in } \mathrm{m}^{3} \text { in } \\
2012^{\mathrm{a}^{* *}}\end{array}$} & No. of households & 33 & 21 & 9 & 63 \\
\hline & Average & $8.9 \mathrm{~m}^{3}$ & $21.3 \mathrm{~m}^{3}$ & $59.8 \mathrm{~m}^{3}$ & \\
\hline \multirow{2}{*}{$\begin{array}{l}\text { Number of trees sold in } \\
2012^{\mathrm{a}^{* * *}}\end{array}$} & No. of households & 33 & 21 & 9 & 63 \\
\hline & Average & 6 & 23 & 35 & \\
\hline \multirow{2}{*}{$\begin{array}{l}\text { Frequency of timber sale } \\
\text { in } 2012^{a}\end{array}$} & No. of households & 33 & 21 & 9 & 62 \\
\hline & Average & 2 & 3 & 3 & \\
\hline \multicolumn{6}{|l|}{$2004-2012$} \\
\hline Without a program ${ }^{b^{* * *}}$ & No. of households & 36 & 19 & 4 & 59 \\
\hline With a program ${ }^{b^{* * *}}$ & & $7(16 \%)$ & $6(24 \%)$ & 7 (64\%) & 20 \\
\hline \multirow{2}{*}{$\begin{array}{l}\text { Did you implement the } \\
\text { program? }\end{array}$} & Yes & 1 & 1 & & \\
\hline & No. of households & $7(88 \%)$ & $5(83 \%)$ & $7(100 \%)$ & \\
\hline \multirow{2}{*}{$\begin{array}{l}\text { Timber sold in } \mathrm{m}^{3} \text { for } \\
\text { different years } \mathrm{s}^{\mathrm{a**}, \mathrm{c}}\end{array}$} & No. of households & 43 & 25 & 10 & 78 \\
\hline & Average & $9.90 \mathrm{~m}^{3}$ & $22.38 \mathrm{~m}^{3}$ & $54.83 \mathrm{~m}^{3}$ & \\
\hline \multirow{2}{*}{$\begin{array}{l}\text { Number of trees sold for } \\
\text { different years }{ }^{\mathrm{a}^{* *}}\end{array}$} & No. of households & 43 & 25 & 11 & 79 \\
\hline & Average & 9 & 22 & 31 & \\
\hline
\end{tabular}

Note: a) ANOVA a in characteristic differences between the types of use at $1 \%\left({ }^{* * *}\right)$ and $5 \%\left({ }^{* *}\right)$ level of significance. b) Pearson Chi-square ${ }^{b}$ is significant at $1 \%\left(^{* *}\right)$ level of significance c) the number of households by sold timber should be 79 , but the information regarding the $\mathrm{m}^{3}$ of standing timber that one smallholder sold could not be obtained.

Source: Own elaboration based on a household survey conducted between August and September 2012.

Table 33. Characteristics of the amount of timber sold with and without a harvesting program and according to ethnic groups and harvesting strategies in Napo between 2011 and 2012

\begin{tabular}{|c|c|c|c|c|}
\hline & & & \multicolumn{2}{|c|}{ Sawn timber $\left(\mathrm{m}^{3}\right)$} \\
\hline & & & Colonists & Kichwas \\
\hline \multirow[t]{4}{*}{ On their own } & \multirow[t]{2}{*}{ Informal } & No. of households & 8 & 28 \\
\hline & & Average & $9.6^{b^{* *}}$ & $6.3^{b^{* * *}}$ \\
\hline & \multirow[t]{2}{*}{ Formal } & No. of households & 3 & 4 \\
\hline & & Average & $30.5^{b^{* *}}$ & $19.6^{b^{* * *}}$ \\
\hline \multirow[t]{4}{*}{ Hired staff } & \multirow[t]{2}{*}{ Informal $^{a^{*}}$} & No. of households & 6 & 13 \\
\hline & & Average & $22.1^{\mathrm{b} * *}$ & $7.8^{b^{*}}$ \\
\hline & \multirow[t]{2}{*}{ Formal } & No. of households & 4 & 2 \\
\hline & & Average & $69.2^{b^{* *}}$ & $24.0^{\mathrm{b}^{*}}$ \\
\hline \multirow{4}{*}{$\begin{array}{l}\text { The intermediary performs the } \\
\text { extraction }\end{array}$} & \multirow[t]{2}{*}{ Informal } & No. of households & 3 & \\
\hline & & Average & 32.1 & \\
\hline & \multirow[t]{2}{*}{ Formal } & No. of households & 7 & \\
\hline & & Average & 64.5 & \\
\hline \multirow[t]{2}{*}{ Total } & & No. of households & 31 & 47 \\
\hline & & Average & 36.3 & 8.6 \\
\hline
\end{tabular}

Note: a) Independent samples t-test between colonists and Kichwas which count with a program and colonists and Kichwas who do not count with a program at $10 \%\left({ }^{*}\right)$ level of significance and b) Independent samples t-test between the same ethnic group at $1 \%\left(^{* *}\right)$ and $5 \%\left({ }^{* *}\right)$ and $10 \%\left(^{*}\right)$ of level of significance.

Source: Own elaboration based on a household survey conducted between August and September 2012. 
and food. Salaries paid to hired staff, including relatives, constitutes the main item that makes the difference between group 1 and 2; thus, salaries represent the highest harvesting cost for group 2 (75\%), with only $38 \%$ in group 1, using family labor. Supplies represent the highest percentage of total costs in harvesting for group 2 (Figure 12).

The cost of transportation has not been determined; however, it is known that $82 \%$ of the households sold timber in their own communities. These smallholders traveled $1.80 \mathrm{~km}$ on average to the point of sale, while the smallholders that sold outside the community traveled around $10.60 \mathrm{~km}$. Smallholders that sell timber within the community usually require animal transport, due to the distance. Smallholders that sell outside the community use animal, river and/or road transport. Transport costs are highly variable and depend on several factors such as topography, number of animals used or number of haulers hired.

Net income varies for each category. Group 1 is characterized by having the lowest net income in the three groups. Groups 2 and 3 have similar net income due to the amount of timber they sell in volume. When estimating the benefits smallholders obtain per $\mathrm{m}^{3}$ of timber sold, smallholders in group 3 receive the lowest income compared with the other groups (Table 34). Even though it is true that the group where smallholders harvest on their own has smaller incomes, the intensity of harvesting was much lower, which is likely to enable rotation in different forest areas over time.

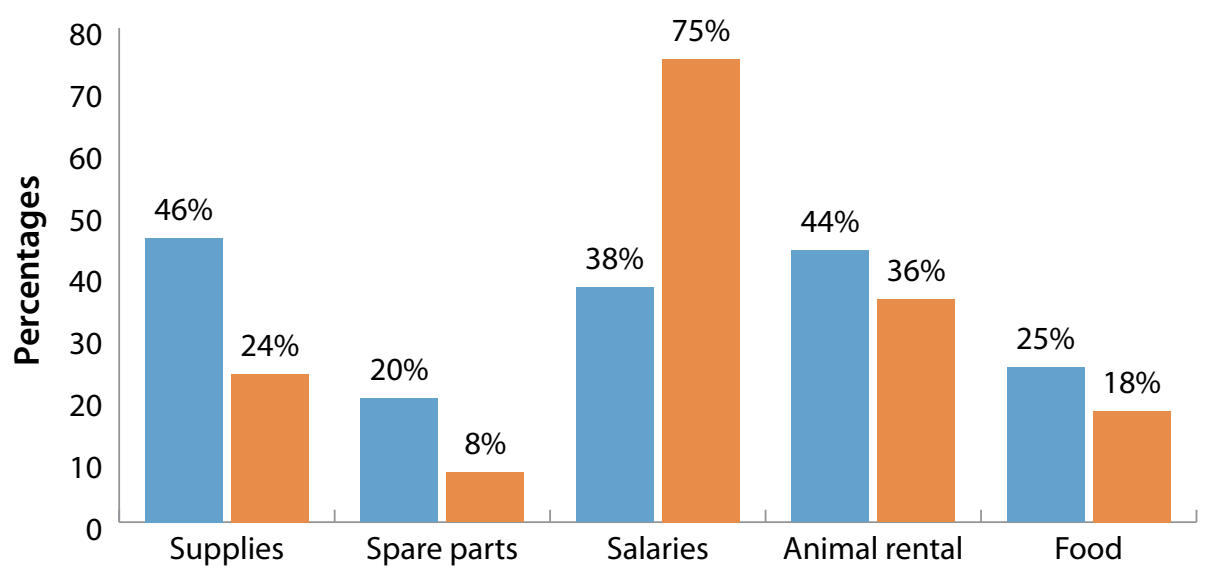

Smallholder who extracts on his own (Group 1) $\quad$ Smallholder who hires staff (Group 2)

Figure 12. Percentage of the total cost for August 2011-September 2012. Based on a survey to households carried out between August and September 2012. Group 3 isn't included because the smallholders didn't have the information about expenses.

Table 34. Costs and benefits of small smallholders for August 2011-September 2012 (in USD)

\begin{tabular}{llll}
\hline & \multicolumn{2}{l}{ Smallholder conducts the extraction } & \multicolumn{2}{l}{$\begin{array}{l}\text { The intermediary } \\
\text { performs the extraction }\end{array}$} \\
\cline { 2 - 4 } & On his own & With hired staff & - \\
\hline Gross income & 555 & 2068 & - \\
Costs & 16 & 910 & 1516 \\
Net income from timber & 369 & 1058 & 26 \\
$\begin{array}{l}\text { Net income from } \mathrm{m}^{3} \text { of sold } \\
\text { timber }\end{array}$ & 48 & 46 & \\
\hline
\end{tabular}

Source: Own elaboration based on a household survey conducted between August and September 2012. 


\subsubsection{Species and amount of timber}

The area where harvesting occurred is the same for the three groups: native forests (40\%), secondary forests (19\%), agroforestry areas $(16 \%)$, silvopastoral areas (14\%), and regenerated secondary forest -fallows (11\%). To compare with harvesting programs, MAE classification has been used, unifying secondary forests, fallows-regenerated secondary forest, and silvopastoral areas in agroforestry systems (Table 35). The total of timber sold in the period from August 2011 to September 2012 is $893 \mathrm{~m}^{3} ; 86 \%$ of this timber is described in Table 35, the lacking $12 \%$ is due to the fact that smallholders were unaware of the amount sold by species. They ignore this information because they do not take part in harvesting where it is done by an intermediary. The remaining $2 \%$ corresponds to timber that is used for domestic purposes in households.

The largest amount of timber for the entire province of Napo does not come from native forests according to data from Table 35. For the first five species sold considering the volume harvested, laurel (Cordia alliodora), balsa (Ochroma pyramidale) and sande rojo (Brosimun spp.) are characterized by originating in areas that are different from native forests in the communities under study.

Table 35. Harvesting by type of species and land use (in $\mathrm{m}^{3}$ )

\begin{tabular}{|c|c|c|c|c|}
\hline & $\begin{array}{l}\text { Native } \\
\text { forests }\end{array}$ & $\begin{array}{l}\text { Agroforestry } \\
\text { systems }\end{array}$ & $\begin{array}{l}\text { Pioneer } \\
\text { formations }\end{array}$ & Total \\
\hline Laurel (Cordia alliodora) $\left(^{*}\right)$ & 15.54 & 81.95 & & 97.49 \\
\hline Doncel, sangre de gallina, (Otoba spp.) (*) & 120.39 & 27.48 & & 147.87 \\
\hline Balsa, boya (Ochroma pyramidale) & & & 132 & 132 \\
\hline Lechero, sande rojo, sande blanco (Brosimun spp.) & & 63.76 & & 63.76 \\
\hline Colorado, manzano, tucuta, piaste (Guarea Kunthiana) $\left(^{*}\right)$ & 33.75 & 17.43 & & 51.18 \\
\hline Guarango, yonrunta (Acacia glomerosa) & 25.54 & & & 25.54 \\
\hline Arenillo, pondo (Erisma uncinatum) $\left(^{*}\right)$ & 32.42 & 1.2 & & 33.62 \\
\hline Chalviande, coco, (Virola spp.) & 21.25 & 12.12 & & 33.37 \\
\hline Ceiba, ceibo, (Ceibainsignis) & 6.91 & 20.33 & & 27.24 \\
\hline Mascarey, motilón (Hyeronima spp.) (*) & 23.94 & 12.30 & & 36.24 \\
\hline Tamburo, bella María, Juan Colorado (Vochysia spp.) (*) & & 20.23 & & 20.23 \\
\hline Abio, caimito (Pouteria spp.) (*) & 12.94 & 7.34 & & 20.28 \\
\hline Higueron, matapalo (Ficus spp.) & & 16.85 & & 16.85 \\
\hline Canelo (Nectandrareticulata) $\left(^{*}\right)$ & 2.88 & 10.50 & & 13.38 \\
\hline Corcho (Apeibamembranacea) & & 8.64 & & 8.64 \\
\hline Sapote (Sterculia spp.) & 7.20 & 4.68 & & 11.88 \\
\hline Copal, anime (Dacryodes spp.) & & 5.34 & & 5.34 \\
\hline Chuncho, seique, (Cedrelinga catenaiformes) (*) & & 4.20 & & 4.20 \\
\hline Other & 1.08 & 20.44 & & 21.52 \\
\hline Total & 303.84 & 334.79 & 132 & 770.62 \\
\hline Percentage & $40 \%$ & $43 \%$ & $17 \%$ & $100 \%$ \\
\hline
\end{tabular}

Note: Species marked with an * belong to hard or semi-hard species, the rest are considered softwood species. Source: Own elaboration based on a household survey conducted between August and September 2012. 


\subsection{The case of Orellana: Analysis of smallholders' strategies}

\subsubsection{Characteristics of households}

The main difference between colonist and indigenous community households is that most of the colonists come from other provinces in the country. The number of household members is higher in indigenous households, the indigenous heads of families are younger, and the level of education of adult Kichwas is lower than in colonist households (Table 36). As regards to tenure, like in Napo, colonists have individual access to their lands although they do not often have an official title, and each indigenous community has a collective title for the whole community, and the allocation of family lands is decided by the community organization. Land tenure is perceived as quite secure even when there is no formal tenure title, although a considerable percentage is registered in some way. In fact, although 27 colonist smallholders declared they did not have property titles of their lands, none of them expressed feeling insecure regarding their tenure rights.

\subsubsection{Land use and production systems}

Production systems of the smallholdings are quite diversified both in the case of colonists and indigenous peoples. Indigenous community smallholdings are slightly larger (40\%) than colonists'. In general, they use the same production systems, characterized by primary forest mosaics, small patches of secondary forest, fallows, pastures, perennial crops like cocoa and coffee for marketing, apart from farms with cassava, platanaceae and other crops to meet families' needs. The main difference between colonist and indigenous lands is the area with forests and pastures. Approximately two thirds of these lands are covered by mature forests, these areas being relatively larger in indigenous household plots. The cultivated area is slightly larger in colonist households than in indigenous ones, especially due to the larger pasture areas in colonist plots (Table 37).

Of the 120 smallholders interviewed, $72 \%$ cleared some forest area in the 2006-2012 period. Conversion activities in the deforested area have taken place more frequently in indigenous households, although the average cleared area per operation is smaller. Nevertheless, both colonists and indigenous cleared an average 3 hectares ( 0.5 hectares per year) in the above period. This suggests that Kichwa households tend to perform smaller-scale but more frequent land clearing activities than colonists, resulting in the same

Table 36. Characteristics of colonist, Kichwa and Shuar households

\begin{tabular}{|c|c|c|c|}
\hline Variables & Colonists & Kichwas & Shuars \\
\hline Origin & $\begin{array}{l}96 \% \text { were not born in } \\
\text { Orellana and come from the } \\
\text { highlands and coast, mainly, } \\
\text { Loja, Bolivar and Manabí. }\end{array}$ & $\begin{array}{l}93 \% \text { were not born in } \\
\text { Orellana and come, mainly, } \\
\text { from the province of Napo. }\end{array}$ & $\begin{array}{l}85 \% \text { were not born in } \\
\text { Orellana and come from } \\
\text { the province of Morona } \\
\text { Santiago. }\end{array}$ \\
\hline $\begin{array}{l}\text { Number of } \\
\text { household } \\
\text { members }\end{array}$ & 4 adults and 2 children & 6 adults and 3 children & 5 adults and 2 children \\
\hline $\begin{array}{l}\text { Average age of } \\
\text { head of household }\end{array}$ & 47 & 39 & \\
\hline \multirow[t]{2}{*}{ Education } & \multicolumn{3}{|c|}{$\begin{array}{l}\text { Formal education levels are low among heads of households. There is no difference } \\
\text { between colonist and indigenous households. The illiteracy rate is } 6 \%(10 \% \text { among } \\
\text { colonists and 3\% among indigenous people), whereas } 79 \% \text { have completed primary } \\
\text { school }\end{array}$} \\
\hline & \multicolumn{3}{|c|}{$\begin{array}{l}\text { Other members (not heads of household) of colonist households show better rates } \\
\text { of primary and secondary formal education with respect to other members of } \\
\text { Kichwa families. }\end{array}$} \\
\hline Type of tenure: & $\begin{array}{l}\text { Individual, } 41 \% \text { have a } \\
\text { register or title. }\end{array}$ & $\begin{array}{l}\text { Communal, } 98 \% \text { have a } \\
\text { record. }\end{array}$ & Communal, $100 \%$ have a title. \\
\hline
\end{tabular}

Source: Own elaboration based on a household survey conducted between February and July 2012. 
Table 37. Land use in hectares in colonist and indigenous (Kichwa and Shuar) plots

\begin{tabular}{|c|c|c|c|c|}
\hline & \multicolumn{2}{|c|}{ Colonists } & \multicolumn{2}{|c|}{ Indigenous people } \\
\hline & Average & Standard deviation & Average & Standard deviation \\
\hline Native forest ${ }^{\mathrm{a}}$ & 23.19 & 22.05 & 39.71 & 26.94 \\
\hline Secondary forest ${ }^{b}$ & 0.38 & 1.23 & 0.78 & 1.63 \\
\hline Regenerated Secondary Forest $^{c}$ & 2.60 & 4.80 & 2.68 & 4.06 \\
\hline Pastures & 6.10 & 6.30 & 3.45 & 3.38 \\
\hline Annual crops ${ }^{d}$ & 0.17 & 0.41 & 0.45 & 0.69 \\
\hline Perennial crops ${ }^{\mathrm{e}}$ & 1.97 & 2.69 & 1.81 & 2.08 \\
\hline Farm ${ }^{f}$ & 0.36 & 0.82 & 0.38 & 0.83 \\
\hline Otherg & & & 1.05 & 2.37 \\
\hline Total & 34.77 & 23.52 & 50.31 & 26.67 \\
\hline
\end{tabular}

Note: a) It refers to undisturbed forests, b) These are naturally regenerating forests, c) It refers to a young secondary forest that has regenerated naturally after being disturbed by human activities, d) It includes corn, banana and cassava, e) It includes cocoa and coffee, $f$ ) it is the area destined for household consumption and it includes, for example, cassava and banana, and g) These are areas which cannot be cultivated, i.e. swamp and rocky areas.

Source: Own elaboration based on a household survey conducted between February and July 2012.

amount of forest converted to agricultural uses. Most of the clearing has occurred in native forests (75\%); another part in secondary forests (4\%); and in fallows or regenerated secondary forests $(21 \%)$. The purpose of land clearing has been to grow pastures, annual crops like maize, and perennial crops like coffee and cocoa. Normally, colonists have a greater preference for the establishment of pastures and perennial crops; Shuar households prefer pastures and annual crops, and Kichwa households prefer perennial crops. The cleared land areas are located relatively close to the households, approximately $1 \mathrm{~km}$ away.

A total of $67 \%$ of the cleared plots were not intervened for timber harvesting before clearing in the above period. Out of the 86 households that cleared land, 57 households had the presence of market demanded species, but only $17 \%$ sold the timber as a result of the absence of valuable species in the lands, the lack of buyers, deficient access roads to the community, and a relatively long distance to the nearest point of sale. The main aim of clearing is to convert forests into agricultural activities, regardless of the availability of timber in those lands (Table 38).

\subsubsection{Total and forest income}

The family economy of surveyed households is characterized by a combination of multiple production and income generation activities. There are no significant differences in the composition
Table 38. Deforestation in Kichwa and colonist plots for 2006-2012

\begin{tabular}{lccr} 
& Colonists & $\begin{array}{c}\text { Indigenous } \\
\text { people }\end{array}$ & Total \\
\hline Total no. of plots & 48 & 72 & 120 \\
$\begin{array}{l}\text { No. of deforested } \\
\text { plots }\end{array}$ & 28 & 58 & 86 \\
$\begin{array}{l}\text { No. of deforested } \\
\text { forests with } \\
\text { previous timber }\end{array}$ & 6 & 23 & 29 \\
$\begin{array}{l}\text { extraction } \\
\text { Main timber }\end{array}$ & Sale & Sale & \\
destination & & & \\
\hline
\end{tabular}

Source: Own elaboration based on a household survey conducted between February and July 2012.

of income received by colonist and indigenous households. Table 39 suggests that for most of the families, agricultural and forest production is the basis of their income, although wage labor outside smallholdings and their own businesses are also important activities for a significant number of families. Agricultural and livestock production, apart from supplying income, are important to ensure families' food source. Regarding income generated outside the plots, wage labor in public institutions (e.g. the Ministry of Education or local government bodies) or the private sector (oil companies based in the province) is particularly 
Table 39. Colonist and indigenous (Kichwa and Shuar) income for February 2011-July 2012

\begin{tabular}{|c|c|c|c|c|c|c|c|c|}
\hline \multirow{3}{*}{ Source of income } & \multicolumn{6}{|c|}{ Average income } & \multicolumn{2}{|c|}{$\begin{array}{l}\text { No. of households that } \\
\text { obtain income from } \\
\text { these activities }\end{array}$} \\
\hline & \multicolumn{2}{|c|}{$\begin{array}{l}\text { Colonists } \\
(n=48)\end{array}$} & \multicolumn{2}{|c|}{$\begin{array}{l}\text { Indigenous } \\
\quad(n=72)\end{array}$} & \multicolumn{2}{|c|}{$\begin{array}{c}\text { Total } \\
(n=120)\end{array}$} & \multirow[t]{2}{*}{ Colonists } & \multirow{2}{*}{$\begin{array}{l}\text { Indigenous } \\
\text { people }\end{array}$} \\
\hline & USD & $\%$ & USD & $\%$ & USD & $\%$ & & \\
\hline Wage labor ${ }^{* * * *}$ & 2052 & 62 & 923 & 47 & 1375 & 55 & 25 & 39 \\
\hline Sale of forest products ${ }^{b}$ & 341 & 10 & 410 & 21 & 382 & 15 & 27 & 39 \\
\hline Human Development Bond ${ }^{c}$ & 210 & 6 & 233 & 12 & 224 & 9 & 24 & 40 \\
\hline Sale of agricultural production ${ }^{d}$ & 217 & 7 & 155 & 8 & 180 & 7 & 34 & 50 \\
\hline Sale of livestock production & 177 & 5 & 150 & 8 & 160 & 6 & 31 & 47 \\
\hline Income from own business ${ }^{f * *}$ & 169 & 5 & 50 & 3 & 98 & 4 & 6 & 10 \\
\hline Other income ${ }^{g}$ & 53 & 2 & 8 & 0 & 26 & 1 & 4 & 1 \\
\hline Total***h & 3298 & 100 & 1945 & 100 & 2486 & 100 & & \\
\hline
\end{tabular}

Note: a) wage labor includes all labor that is carried out outside the smallholding and paid, for example, agricultural labor, sawmilling and labor under work contracts; b) forest income refer to income in cash for the sale of timber, non-timber forest products (NTFPs) and Income from the Government's Socio Bosque Program (PSB); c) the Human Development Bond has already been explained; $d$ ) the sale of agricultural production refers to the cash income from the sale of these type of products, for example, cocoa, corn, coffee, guayusa, etc; e) the sale of livestock production is obtained from the sale of animals or their by-products, for example, cattle, chickens and milk, among others; $f$ ) income from own business refers to any activity in which the smallholder works on his own, i.e., he is his own boss; for example, merchants or store owners; g) other income refers to income that is not part of any of the above categories; $h$ ) Independent samples t-test in the differences of income diversification between colonists and Kichwas at $1 \%\left(^{* * *}\right)$ and $5 \%\left({ }^{* *}\right)$ level of significance.

Source: Own elaboration based on a household survey conducted between February-July 2012.

important. Their own businesses mainly refer to small business activities, but they also include other activities like transport service provision or sale of crafts. The Human Development Bond is also a relevant economic aid for many rural families in the province.

From February 2011 and July 2012, there were 66 households (55\%) that had income related to the sale of forest products. Timber is the most important source of income among forest products. Although forests have a potential to generate significant profits, they constitute the only source of family income only for a few families. Taking as a basis the overall figure of 120 interviewed households, timber sale constitutes $10 \%$ of the total annual income for colonist families and 22\% for indigenous households in this period. However, in absolute terms, the amount of timber sold per year on average is relatively similar for colonists and for indigenous groups. It is important to note that, for the households selling timber (66), income from timber products is higher in household's total annual income, $18 \%$ in colonist families $(0.40 \%-100 \%)$ and $41 \%$ in Kichwa families (3\%-100\%) (Table 40).

Similarly to what was mentioned regarding the households interviewed in the province of Napo, forest income does not seem to play a central role in family safety mechanisms in response to a crisis or unexpected events in the households interviewed in Orellana province. A total of 73 households (61\%) experienced some kind of crisis or unexpected expense in the year before the survey, but only 12 $(16 \%)$ said that they had sold more forest products to address these issues (Figure 13).

Since timber is a major source of income, households look for strategies to maintain this income in the future by growing species like chuncho (Cedrelinga catenaiformes), mahogany/ ahuano (Swietenia macrophylla) and guayacán (Tabebuia chrysanthemum), among others. Of all interviewees, 70 households (58\%) declared they had planted trees of these species in their lands. 


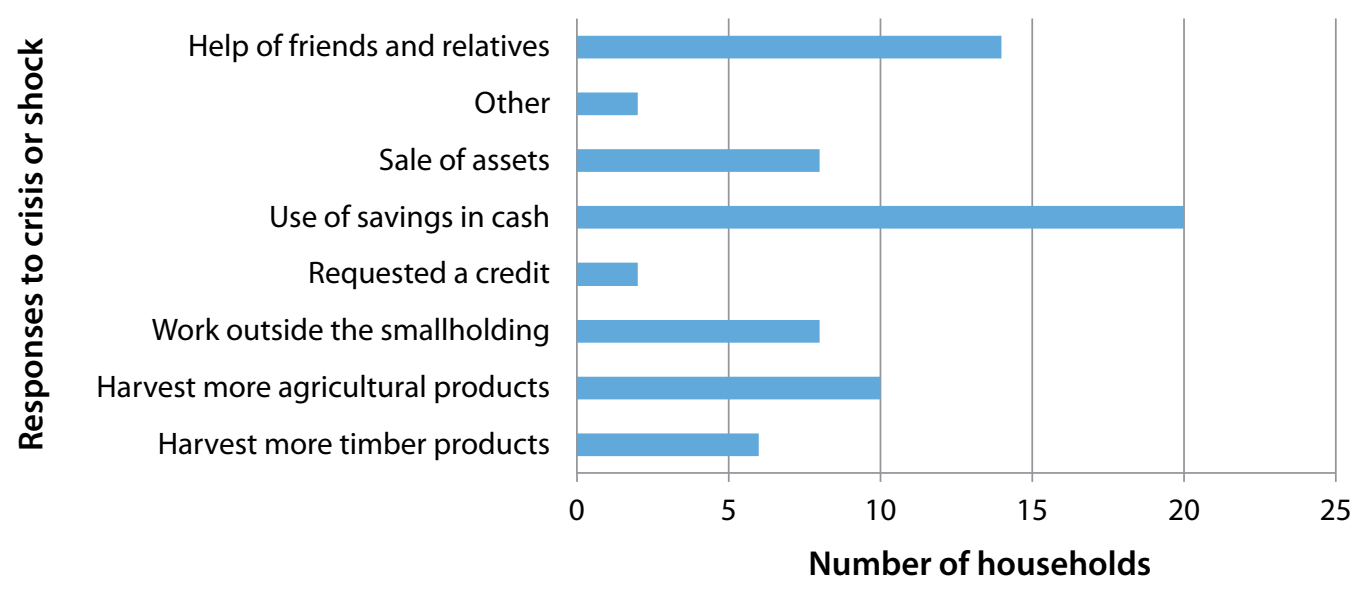

Figure 13. Role of forestry income in family security mechanisms in crisis or contingency situations. Based on a survey to households carried out between February and July 2012.

Table 40. Description of forest income from timber and non-timber products for February 2011July 2012

\begin{tabular}{|c|c|c|c|c|c|c|c|c|}
\hline \multirow{3}{*}{ Forest income } & \multicolumn{6}{|c|}{ Average income } & \multicolumn{2}{|c|}{$\begin{array}{l}\text { No. of households that obtain } \\
\text { income from these activities }\end{array}$} \\
\hline & \multicolumn{2}{|c|}{ Colonists $(n=8)$} & \multicolumn{2}{|c|}{$\begin{array}{l}\text { Indigenous } \\
\quad(n=72)\end{array}$} & \multicolumn{2}{|c|}{ Total $(n=120)$} & \multirow[t]{2}{*}{ Colonists } & \multirow[t]{2}{*}{ Kichwas } \\
\hline & USD & $\%$ & USD & $\%$ & USD & $\%$ & & \\
\hline Total income ${ }^{* * *}$ & 3298 & 100 & 1945 & 100 & 2486 & 100 & 48 & 72 \\
\hline \multicolumn{9}{|l|}{ Total forest income } \\
\hline Sale of timber & 332 & 10 & 426 & 22 & 388 & 16 & 27 & 39 \\
\hline $\begin{array}{l}\text { Sale of non-timber forest } \\
\text { products (NTFPs) }\end{array}$ & 11 & 0.3 & 1 & 0 & 4 & 0.2 & 2 & 1 \\
\hline Socio Bosque Program & 31 & 1 & 0 & 0 & 13 & 1 & 1 & 0 \\
\hline
\end{tabular}

Note: a) Independent samples t-test in the differences of income diversification between colonists and Kichwas at $1 \%\left({ }^{* * *}\right)$ of level of significance.

Source: Own elaboration based on a household survey conducted between February and July 2012.

\subsection{Differentiated strategies for timber harvesting}

This section uses a typology that is similar to that used for the same analysis presented in the case of Napo province. Three groups have been identified: group 1 corresponds to the smallholders that harvest on their own; group 2 refers to the smallholders that employ staff; group 3 consists of the smallholders that sell timber to intermediaries, who harvest; and group 4 refers to the smallholders that are not devoted to timber sale. Tables 41 and 42 present the main features of the different households according to this classification.

The information presented indicates that most of the smallholders that do the harvesting own chainsaws with which they can work in timber harvesting, apart from having a larger number of family members in the household, which differentiates them from the other groups that probably need to hire labor or find other harvesting strategies. Groups 2 and 3 are characterized by receiving lower income for their paid jobs 
Table 41. Types according to household attributes and the strategy of forest resources harvesting

\begin{tabular}{|c|c|c|c|c|}
\hline & \multicolumn{2}{|c|}{$\begin{array}{c}\text { The smallholder performs } \\
\text { the extraction }\end{array}$} & \multirow{2}{*}{$\begin{array}{l}\text { The intermediary } \\
\text { carries out all the } \\
\text { extraction }\end{array}$} & \multirow{2}{*}{$\begin{array}{l}\text { Timber is not } \\
\text { sold }\end{array}$} \\
\hline & On his own & With hired staff & & \\
\hline \multicolumn{5}{|l|}{ Household characteristics } \\
\hline Number of households & 43 & 11 & 35 & 31 \\
\hline $\begin{array}{l}\text { Ethnic group of the head of } \\
\text { household }^{b}\end{array}$ & \multicolumn{4}{|c|}{$40 \%$ colonists and $60 \%$ indigenous ( $37 \%$ Kichwas and $23 \%$ Shuars) } \\
\hline Gender of head of household ${ }^{b}$ & \multicolumn{4}{|l|}{$4 \%$ are women } \\
\hline $\begin{array}{l}\text { Number of people per household } \\
\mathrm{a}^{* * *}\end{array}$ & 6 people & 3 people & 5 people & 4 people \\
\hline Number of adults per household ${ }^{\text {a }}$ & 4 people & 2 people & 3 people & 3 people \\
\hline Age of head of household ${ }^{b}$ & \multicolumn{4}{|c|}{$58 \%$ are under 45 and the rest are over 45} \\
\hline Age of head of household ${ }^{a}$ & \multicolumn{4}{|l|}{ Average age is 42.} \\
\hline Smallholding size (ha) $)^{\mathrm{a}^{* *}}$ & $\begin{array}{l}\text { It has on average } \\
48 \text { hectares }\end{array}$ & $\begin{array}{l}\text { It has on average } \\
33 \text { hectares }\end{array}$ & $\begin{array}{l}\text { It has on average } \\
56 \text { hectares }\end{array}$ & $\begin{array}{l}\text { It has on average } \\
38 \text { hectares }\end{array}$ \\
\hline Cultivated smallholding size (ha) ${ }^{\mathrm{a}}$ & It has on average & hectares & & \\
\hline \multirow{4}{*}{$\begin{array}{l}\text { Work outside the smallholding }{ }^{b^{*}} \\
\text { (laborer) and } b^{* * *} \text { (sawyer) }\end{array}$} & \multicolumn{4}{|c|}{$19 \%$ of all households had a work contract in the last 12 months } \\
\hline & $\begin{array}{l}49 \% \text { work as } \\
\text { outside the } \\
\text { smallholding } \\
\text { laborers }\end{array}$ & $\begin{array}{l}18 \% \text { work as } \\
\text { outside the } \\
\text { smallholding } \\
\text { laborers }\end{array}$ & $\begin{array}{l}26 \% \text { work as } \\
\text { outside the } \\
\text { smallholding } \\
\text { laborers }\end{array}$ & $\begin{array}{l}48 \% \text { work as } \\
\text { outside the } \\
\text { smallholding } \\
\text { laborers }\end{array}$ \\
\hline & $\begin{array}{l}28 \% \text { receive } \\
\text { income }\end{array}$ & $\begin{array}{l}9 \% \text { receive } \\
\text { income }\end{array}$ & $\begin{array}{l}3 \% \text { receive } \\
\text { income }\end{array}$ & $\begin{array}{l}32 \% \text { receive } \\
\text { income }\end{array}$ \\
\hline & $\begin{array}{l}\text { as outside the } \\
\text { smallholding } \\
\text { sawyers }\end{array}$ & $\begin{array}{l}\text { as outside the } \\
\text { smallholding } \\
\text { sawyers }\end{array}$ & $\begin{array}{l}\text { as outside the } \\
\text { smallholding } \\
\text { sawyers }\end{array}$ & $\begin{array}{l}\text { as outside the } \\
\text { smallholding } \\
\text { sawyers }\end{array}$ \\
\hline Savings account ${ }^{b}$ & \multicolumn{4}{|c|}{$\begin{array}{l}84 \% \text { of households do not have access to a savings account in a bank, } \\
\text { cooperative, association, etc. }\end{array}$} \\
\hline \multicolumn{5}{|l|}{ Assets } \\
\hline Mobile phone and canoes ${ }^{b}$ & \multicolumn{4}{|c|}{$51 \%$ of households have mobile phones and about $2 \%$ have canoes } \\
\hline Chainsaw $\mathrm{b}^{* * *}$ & $\begin{array}{l}81 \% \text { have } \\
\text { chainsaws }\end{array}$ & $\begin{array}{l}55 \% \text { have } \\
\text { chainsaws }\end{array}$ & $\begin{array}{l}40 \% \text { have } \\
\text { chainsaws }\end{array}$ & $\begin{array}{l}42 \% \text { have } \\
\text { chainsaws }\end{array}$ \\
\hline Cattle $^{\mathrm{b}}$ & \multicolumn{4}{|l|}{$68 \%$ have cattle } \\
\hline Pack animals b*** $^{* * 1}$ & $\begin{array}{l}65 \% \text { have } \\
\text { animals }\end{array}$ & $\begin{array}{l}18 \% \text { have } \\
\text { animals }\end{array}$ & $\begin{array}{l}26 \% \text { have } \\
\text { animals }\end{array}$ & $26 \%$ have animals \\
\hline Total assets (USD) ${ }^{\mathrm{a}}$ & \multicolumn{4}{|c|}{ USD 1248 (on average) } \\
\hline Distance to main a town & \multicolumn{4}{|c|}{ The average distance of the communities to ciudad del Coca is 29.8 miles. } \\
\hline
\end{tabular}

Note: a) it refers to the results of the Analysis of Variance (ANOVA) in characteristic differences between the types of harvesting at $1 \%\left({ }^{* *}\right), 5 \%\left({ }^{* *}\right)$ and $10 \%\left({ }^{*}\right)$ of level of significance. b) Pearson Chi-square is significant at $1 \%\left({ }^{* *}\right), 5 \%\left({ }^{* *}\right)$ and $10 \%\left({ }^{*}\right)$ of level of significance.

Source: Own elaboration based on a household survey conducted between February and July 2012. 
compared mainly with the group that does not sell timber. Finally, group 3 is characterized also by having a better relative level of education among heads of households and a higher average age of heads of households.

\subsubsection{Timber harvesting strategies}

A total of 89 households (74\%) sold timber between 2004 and September 2012, while 66 households sold timber from February 2011 to July 2012. Based on the 89 households and the above extraction and marketing strategies, they account for $48 \%$ for group 1, $12 \%$ for group 2 and $39 \%$ for group 3. As discussed above, group 1 includes the smallholders that perform harvesting mostly using family labor, group 2 hires labor for the harvesting, and group 3 involves intermediaries, who are in charge of the harvesting.

While colonists take their decisions individually, Kichwa and Shuar households (the same share) request permission from their communities to harvest and sell timber; approximately $43 \%$ of the households asked for permission from their communities. An important part of the timber harvesting is done in the smallholdings, especially for group 3. However, harvesting also occurs outside smallholdings although in a smaller proportion. This harvesting is done in smallholdings within the community, although it can also be done in smallholdings located in other communities (Table 42).

Purchase negotiations occur mainly through purchase orders of the buyer (66\%), and in other cases producers find a buyer (34\%), especially before logging. A total of $65 \%$ of smallholders have received advance payments for the sale of their timber in order to finance extraction activities when buyers do not carry out this process; the amount received ranges between USD 20 and 1500. This money that is paid in advance would help make up for the lack of the smallholders' sources of financing. Buyers of timber are often intermediaries, most of whom smallholders are already acquainted with. However, the buyer is not always the same person, as half of the respondents said they sell to different buyers. Most of the timber is marketed within the community; only $7 \%$ is sold outside.

On average, $68 \%$ of all the operations made by the three categories were completed without any forest harvesting program. The smallholders that complete the operation through an intermediary sell the largest amount of timber compared with the other groups; i.e. the operations carried out by the smallholders tend to extract and mobilize smaller volumes of timber (Table 43).

Most of the households sell their timber as sawn timber, but standing trees are sold as well. Out of a total of 89 households that perform harvesting, 12 of them sold standing trees to group 3. In general, the informality of timber harvesting is present in all the strategies used by the smallholders. In most cases, the volumes of both standing trees and sawn timber are larger when they are extracted under a forest harvesting program (Table 44). The amount of sawn timber sold does not significantly

Table 42. Characteristics of harvesting by form of harvesting

\begin{tabular}{|c|c|c|c|c|}
\hline & & \multicolumn{2}{|c|}{$\begin{array}{l}\text { Smallholder conducts } \\
\text { the extraction }\end{array}$} & \multirow{2}{*}{$\begin{array}{l}\text { Intermediary } \\
\text { conducts the } \\
\text { extraction }\end{array}$} \\
\hline & & On his own & $\begin{array}{l}\text { With hired } \\
\text { staff }\end{array}$ & \\
\hline \multirow{2}{*}{$\begin{array}{l}\text { Requested permission from } \\
\text { the community }\end{array}$} & Yes & $18(45 \%)$ & $2(22 \%)$ & $16(47 \%)$ \\
\hline & No & $22(55 \%)$ & $7(78 \%)$ & $18(53 \%)$ \\
\hline \multirow[t]{2}{*}{ Place of timber extraction } & Own smallholding & $35(81 \%)$ & $8(73 \%)$ & 34 (97\%) \\
\hline & Outside the smallholding & $8(19 \%)$ & $3(27 \%)$ & $1(3 \%)$ \\
\hline \multirow[t]{2}{*}{ Place of sale of timber } & In the community & $39(95 \%)$ & $9(72 \%)$ & $21(95 \%)$ \\
\hline & Outside the community & $2(5 \%)$ & $2(18 \%)$ & $1(5 \%)$ \\
\hline
\end{tabular}

Source: Own elaboration based on a household survey conducted between February and July 2012. 
Table 43. Characteristics of the sale of timber according to the form of harvesting

\begin{tabular}{|c|c|c|c|c|c|}
\hline & & \multicolumn{2}{|c|}{$\begin{array}{c}\text { The smallholder performs } \\
\text { the extraction }\end{array}$} & \multirow{2}{*}{$\begin{array}{l}\text { The intermediary } \\
\text { performs the } \\
\text { extraction }\end{array}$} & \multirow[t]{2}{*}{ Total } \\
\hline & & On his own & With hired staff & & \\
\hline \multicolumn{6}{|c|}{ Period February 2011-July 2012} \\
\hline Without a program & \multirow[t]{2}{*}{ No. of households } & 30 & 4 & 13 & 47 \\
\hline With a program & & $7(19 \%)$ & $3(43 \%)$ & $9(41 \%)$ & 19 \\
\hline \multirow{2}{*}{ Timber sold in $\mathrm{m}^{3}$ in $2012^{\mathrm{a}^{* * *}}$} & No. of households & 34 & 6 & 18 & 58 \\
\hline & Average & $12.4 \mathrm{~m}^{3}$ & $29.9 \mathrm{~m}^{3}$ & $38.8 \mathrm{~m}^{3}$ & \\
\hline \multirow{2}{*}{$\begin{array}{l}\text { Number of trees sold in } \\
2012^{a^{*}}\end{array}$} & No. of households & 33 & 5 & 22 & 60 \\
\hline & Average & 13 & 5 & 25 & \\
\hline \multicolumn{6}{|l|}{ Period 2004-2012 } \\
\hline Without a program ${ }^{b}$ & \multirow[t]{2}{*}{ No. of households } & 35 & 7 & 23 & 65 \\
\hline With a program & & $14(29 \%)$ & $4(40 \%)$ & $12(34 \%)$ & 30 \\
\hline \multirow{2}{*}{$\begin{array}{l}\text { Timber sold in } \mathrm{m}^{3} \text { in different } \\
\text { years }{ }^{\mathrm{a}^{*}, \mathrm{c}}\end{array}$} & No. of households & 42 & 10 & 22 & 74 \\
\hline & Average & $21.1 \mathrm{~m}^{3}$ & $37.9 \mathrm{~m}^{3}$ & $43.7 \mathrm{~m}^{3}$ & \\
\hline \multirow{2}{*}{$\begin{array}{l}\text { Number of trees sold in } \\
\text { different years }{ }^{a, c}\end{array}$} & No. of households & 43 & 8 & 35 & 86 \\
\hline & Average & 17 & 10 & 22 & \\
\hline
\end{tabular}

Note: a) it refers to the results of the Analysis of Variance (ANOVA) in characteristic differences between the types of use at $1 \%$ $\left({ }^{* *}\right)$ and $10 \%\left({ }^{*}\right)$ of level of significance. $\left.b\right)$ the number of households that have sold timber is 89 ; However, the total of those who sold timber following or not a program is 95 , this is due to the fact that 6 smallholders sold timber both following and not following a program and c) the sale of timber and trees does not reach 89 cases, since some smallholders sold standing timber and others did not remember the amount they had sold.

Source: Own elaboration based on a household survey conducted between February and July 2012.

Table 44. Characteristics of the amount of timber sold with and without a harvesting program according to ethnic groups and harvesting strategies in Orellana

\begin{tabular}{|c|c|c|c|c|}
\hline & & & Sav & $\operatorname{ber}\left(m^{3}\right)$ \\
\hline & & & Colonists & Indigenous people \\
\hline On their own & Informal & No. of households & 13 & 21 \\
\hline & & Average & $13.3^{\mathrm{c}^{* *}}$ & $11.2^{\mathrm{c}^{* * *}}$ \\
\hline & Formal & No. of households & 2 & 11 \\
\hline & & Average & $18.7^{\mathrm{c}^{* *}}$ & $40.8^{\mathrm{c}^{* * *}}$ \\
\hline With hired staff & Informala ${ }^{*}$ & No. of households & 4 & 2 \\
\hline & & Average & 13.0 & $3.7^{\mathrm{c}^{* * *}}$ \\
\hline & Formal & No. of households & 2 & 2 \\
\hline & & Average & 34.0 & $80^{c^{* * *}}$ \\
\hline The intermediary & Informal & No. of households & 4 & 8 \\
\hline performs the extraction & & Average & 12.3 & $13.9^{9^{* * *}}$ \\
\hline & Formal & No. of households & 1 & 9 \\
\hline & & Average & 50.0 & $80.4^{4^{* * *}}$ \\
\hline Total & & No. of households ${ }^{b}$ & 26 & 53 \\
\hline & & Average & 18.9 & 35.5 \\
\hline
\end{tabular}

Note: a) Independent samples t-test with and without harvesting programs at $10 \%\left({ }^{*}\right)$ level of significance, b) the total amount of households is 79; however it should be 74 , as shown in table 41 . The difference is due to the fact that some households have sold timber in the last year with and without following a harvesting program, thus making figures increase. With the data obtained from Kichwa households an independent samples t-test was conducted among this ethnic group at $1 \%\left({ }^{* * *}\right)$ of level of significance.

Source: Own elaboration based on a household survey conducted between February and July 2012. 
differ between colonists and indigenous people, except for group 2, where the indigenous people sell much less than colonist households. In the case of Orellana, it is known that most households receive money in cash in advance for timber harvesting; this is known as an advance payment. However, in group 2 harvesting is carried out probably without any advance payment, which implies that these indigenous households did not have enough resources for larger-scale harvesting. Although group 3 tends to harvest larger volumes, they also perform small timber harvesting operations, often informally, especially when they need to complete the volumes for larger orders.

\subsubsection{Costs and benefits of harvesting}

The cost analysis includes the expenses covered by the smallholder in the use of inputs, spare parts, salaries, animal rental and food, as explained above in the analysis of the province of Napo. For
Orellana, the main expenses are workers' salaries for both groups. For group 2, the main expenses within total expenses are payments to workers, equipment and animal rental. For group 1, most expenses are associated with payments to workers and supply/input purchases. Salary expenses are high with respect to total expenses, which does not mean that they are the same as for those who hire staff (Figure 14).

Net income from February 2011 to July 2012 was recorded. Net income from timber does not vary significantly between groups. Income from group 3 is expected to be higher since an intermediary would not conduct a small operation. One of the reasons is that intermediaries bought small amounts from these producers to be able to complete the trip of a program. Regarding the payment made to producers per $\mathrm{m}^{3}$, group 3 is the one that receives the lowest income of the three groups (Table 45).

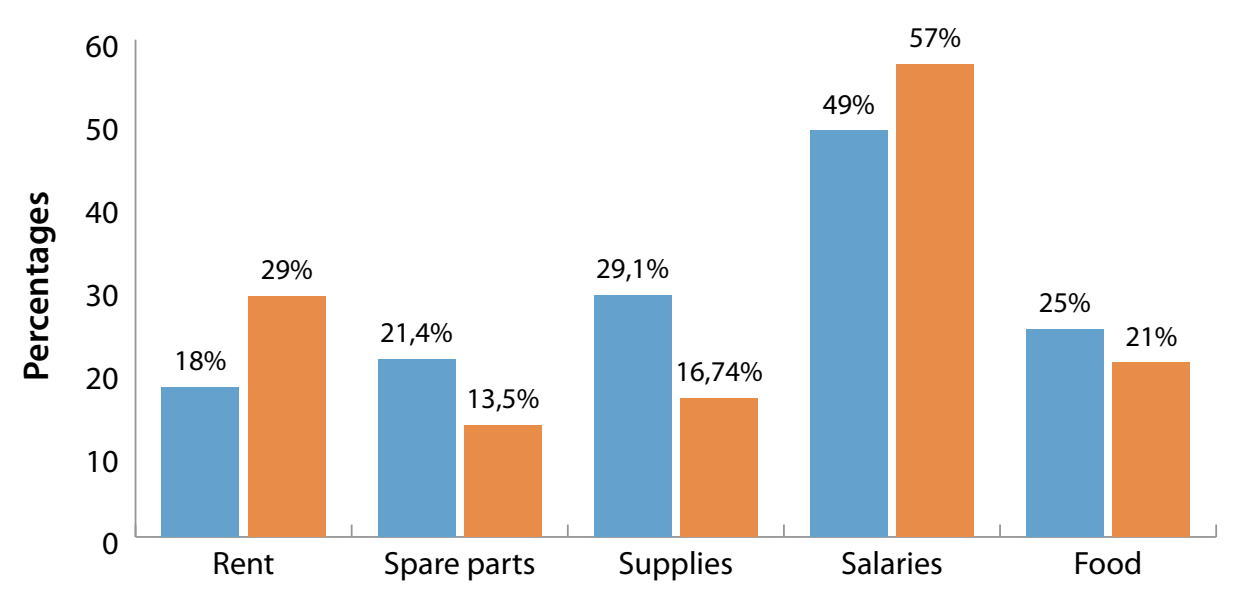

Smallholder who extracts on his own (Group 1) Smallholder who hires staff (Group 2)

Figure 14. Percentage of the total cost for February 2011-July 2012. Based on a survey to households carried out between August and September 2012. Group 3 is not included because the smallholders did not have the information about expenses.

Table 45. Costs and benefits of small smallholders for February 2011-July 2012 (in USD)

\begin{tabular}{lccc} 
& \multicolumn{2}{c}{ Smallholder conducts the extraction } & $\begin{array}{c}\text { The intermediary } \\
\text { performs the extraction }\end{array}$ \\
\cline { 2 - 4 } & On his own & With hired staff & 2032 \\
Gross income & 970 & 1090 & - \\
Costs & 295 & 942 & 747 \\
Net income from timber & 675 & 49 & 30 \\
Net income from $\mathrm{m}^{3}$ of & 60 & & \\
sold timber & & & \\
\hline
\end{tabular}

Source: Own elaboration based on a household survey conducted between February and July 2012. 


\subsubsection{Species and amount of timber}

To compare harvesting programs, the MAE classification which harmonizes secondary forests, fallows-regenerated secondary forests and silvopastoral areas in agroforestry systems has been used. Table 46 shows an estimate of the amount sold by smallholders in Orellana; the largest amount of timber sold comes mainly from native forests.

\subsection{Summary of findings with regards to timber harvesting by smallholders}

In Orellana, households are characterized by having larger plots than in Napo. Indigenous groups in the province usually have access to a larger land and forest area than indigenous peoples in Napo, which can be due to the fact that Napo is an older province, where a greater fragmentation of the plots between the different household members has occurred over time. As a result of the plot fragmentation, the area of secondary forest and regenerated secondary forest is also larger in Napo. The area devoted to crops is similar in both provinces, although households of colonist families tend to cultivate a larger area with crops, mainly for the establishment of pastures.

Between 2006 and 2012, a larger number of households have converted forests to agricultural uses in the province of Orellana (86) than in Napo (71). It is assumed that in Orellana there is more pressure on native forests since households in this province have a larger area of native forests than in Napo. In both provinces, $64 \%$ of the cleared plots were not intervened for timber harvesting, mainly due to the absence of valuable species, the lack of access roads and absence of buyers. Land is cleared for agricultural and cattle-ranching activities, which provide consumption goods and contribute to income generation of colonist and indigenous families.

Production systems in the smallholdings are characterized by being relatively diversified, agriculture being the most common activity done by smallholders. In general, colonist households show higher incomes than indigenous households both in Orellana and in Napo, the latter being higher than in Orellana due to the fact that salary income outside the smallholding is twice as much as the same income in Napo. The main source of income in both provinces is paid employment, which includes both work in other smallholdings and work agreements outside the smallholdings or rural areas. Of the 140 households that receive income for their paid jobs, 45 associate them with chainsaw milling, which represents $23 \%$ of the total of income perceived as salaries.

Table 46. Use by type of species and land use (in $\mathrm{m}^{3}$ )

\begin{tabular}{|c|c|c|c|}
\hline & Native forests & Agroforestry systems & Total \\
\hline Arenillo, pondo (Erisma uncinatum) $\left(^{*}\right)$ & 178.04 & 9.65 & 187.69 \\
\hline Chuncho, seique, (Cedrelinga catenaiformes) $\left(^{*}\right)$ & 136.54 & 4.80 & 141.34 \\
\hline Doncel, sangre de gallina, (Otoba spp.) $\left(^{*}\right)$ & 115.6 & & 115.6 \\
\hline Laurel (Cordia alliodora) $\left(^{*}\right)$ & & 81.57 & 81.57 \\
\hline Chalviande, coco, (Virola spp.) & 67.35 & 6.75 & 74.1 \\
\hline Ceiba, ceibo, (Ceibainsignis) & 30.63 & & 30.63 \\
\hline Tamburo, bella María, Juan Colorado (Vochysia spp.) $\left(^{*}\right)$ & 36.9 & 4.50 & 41.40 \\
\hline Canelo (Nectandrareticulata) $\left(^{*}\right)$ & 14.12 & 6.94 & 21.06 \\
\hline Colorado, manzano, tucuta, piaste (Guarea Kunthiana) $\left(^{*}\right)$ & 15.75 & & 15.75 \\
\hline Other & 12.15 & 2.41 & 14.56 \\
\hline Total & 607.14 & 116.62 & 723.76 \\
\hline Percentage & $84 \%$ & $16 \%$ & $100 \%$ \\
\hline
\end{tabular}

Note: Species marked with an * belong to hard or semi-hard species, the rest are considered softwood species.

Source: Own elaboration based on a household survey conducted between February and July 2012. 
Between $64 \%$ and $74 \%$ of the households interviewed have received income for the sale of timber in Napo and Orellana, mostly between 2004 and 2012, respectively. Instead, last year when the interviews were carried out, only $53 \%$ of the interviewed households received income from the sale of timber, due to the fact that not all households cut timber in this period. This indicates that timber harvesting, and hence income derived from this activity, is relatively irregular over time. On average, income from timber represents $16 \%$ of the total income of all the households interviewed. This income differs between colonists and indigenous peoples for both provinces. In Napo, sales of timber are higher in colonist households than in indigenous households. In Orellana, income derived from the sale of timber is the same for both groups in absolute terms. In turn, indigenous people from Orellana receive approximately twice the income from the sale of timber in Napo, which can be due to the larger forest areas these groups have access to in Orellana compared with Napo.

The most sold species differ by province, since Orellana harvests more valuable species than Napo according to the report by MAE Technical Offices (Oficinas Técnicas) for 2011. In Napo the main four species are laurel (Cordia alliodora), doncel (Otoba spp), balsa (Ochroma pyramidale), and sande rojo (Brosimun spp.). In Orellana, the main species are arenillo (Erisma uncinatum), chuncho (Cedrelinga catenaiformes), doncel (Otoba spp.), and laurel (Cordia alliodora). In Orellana, most of the harvesting is conducted in native forests and in Napo. In Napo, 60\% occurs in secondary forests, agroforestry areas, silvopastoral areas, and regenerated secondary forests.
The households have implemented activities of reforestation on their own for valuable species to be used in the future. This reveals the interest in forest losses and shows that reforestation is probably considered complementary to its other production activities, which states how certain activities can be managed by smallholders. The species that raise the greatest interest among smallholders are chuncho (Cedrelinga catenaiformes), mahogany/ahuano (Swietenia macrophylla), guayacán (Tabebuia chrysantha), and cedar (Cedrela odorata), among others. These are valuable species that have a better price in the market due to their timber, so they are broadly recognized by smallholders both in Orellana and in Napo, thus becoming a source of income for smallholders in the future.

A typology was used to analyze harvesting and benefits of smallholders, as discussed above in detail. The strategies used by smallholders differ by province. In Napo, $86 \%$ of the smallholders intervene in-or lead-harvesting operations, while this percentage is $60 \%$ in Orellana. This shows that the rest is exclusively made by the intermediary without smallholder participation in the harvesting, a procedure that is more common in Orellana. This might be due to the presence of a stronger, more organized intermediation network in Orellana than in Napo. The characteristics of the negotiation with buyers are very similar in both provinces, since most of the smallholders sell their timber through a purchase order, and the rest find a buyer. In Orellana, more than half of the smallholders received an advance payment, while in Napo this amount was quite lower. This money helps to cover the lack of sources of financing of the smallholders (Table 47). Most of the timber is harvested in the smallholding itself and sold within

Table 47. Comparative information between Napo and Orellana

\begin{tabular}{lll}
\hline & Households in the province of Napo & Households in the province of Orellana \\
\hline $\begin{array}{l}\text { Did you contact the buyer } \\
\text { or received an order? }\end{array}$ & $56 \%$ received a purchase order & $66 \%$ received a purchase order \\
$\begin{array}{l}\text { Do you always sell to the } \\
\text { same buyer? }\end{array}$ & $75 \%$ sell to the same buyer & $50 \%$ sell to the same buyer \\
$\begin{array}{l}\text { Did you receive an advance } \\
\text { payment for the purchase } \\
\text { of timber? }\end{array}$ & $15 \%$ received an advance payment & $65 \%$ received an advance payment \\
\hline
\end{tabular}

Source: Own elaboration based on a household survey conducted between February and September 2012. 
the community. Thus, the buyer is the one in charge of timber transport from the community to the end market.

Timber harvesting without an approved program amounts to $69 \%$ and $75 \%$ of total harvesting in Orellana and Napo respectively. In general, timber volumes sold from harvesting operations with approved programs are larger than without approved programs. One of the differences found between the harvesting strategies between the provinces is that the intermediaries that conduct forest harvesting operations with smallholders tend to buy timber of informal origin more frequently in Orellana than in Napo, in order to complete the timber quota of approved programs that did not manage to harvest the authorized volume due to pathological or mechanical damage to trees. In Napo, the number of households that sell without a harvesting program is larger in households of indigenous peoples than colonists; on the contrary, in Orellana, the number of households that sell without a program is larger among colonists than indigenous peoples.

The most frequent expenses covered in by smallholders when leading the harvesting are salaries, inputs, animal rental, food, and spare parts. Net income received by the smallholders that perform the operation on their own is higher in Orellana than in Napo. This can be due to the fact that for this group there are more indigenous families in Napo, which get much lower incomes than the indigenous people in Orellana. Net income per volume of timber sold in $\mathrm{m}^{3}$ by the group of intermediaries that perform harvesting operations is lower on average, compared with the smallholders that harvest on their own both in Napo and in Orellana. Finally, net income by $\mathrm{m}^{3}$ in Orellana is higher than in Napo, which may be because higher fine wood sales are reported in Orellana. 


\title{
Small-scale timber harvesting
}

\author{
Elena Mejía, Guido Fernández, Marco Vinueza, and Álvaro Fuentes
}

Native forests should be harvested in compliance with the forest legislation, which is briefly discussed in chapter 3. Legislation on forest harvesting provides for the implementation of a Logging and Harvesting Program in smallscale operations, usually associated with timber chainsawing and legal land conversion plans. However, as suggested in chapter 4, a significant part of timber harvesting does not occur under approved management programs.

An aspect associated with small-scale timber harvesting consists of benefit distribution between different actors involved in forest operations, especially smallholders who own forest land. On one hand, Mederski (2006) and FAO (2012) suggest that smallholders' profits from harvesting operations tend to be significantly reduced, since an important part is retained by intermediaries. On the other hand, other authors indicate that intermediaries play an important role in the timber business and that without them timber trade would be more difficult (Palacios and Malessa, 2010; Vásquez, 2011; Medjibe and Putz, 2012). These opposing perspectives suggest that better empirical data are required on benefit distribution in different forest harvesting situations in the Ecuadorian Amazon.

This analysis helps to understand better the cost and benefit distribution based on empirical information derived from the monitoring of timber harvesting operations carried out through small-scale formal and informal programs in the provinces of Napo and Orellana. The obtained results enable the characterization of the economic and production performance of the different timber harvesting systems. The criteria used to identify different types of harvesting refer to the forms of smallholder participation in these operations, and whether timber harvesting has been formally approved in accordance with the current forest legislation.

A total of eight communities in the provinces of Orellana and Napo were selected to gather information on the performance of small-scale timber harvesting operations. These communities are located in the main paved roads and secondary roads where timber is transported, particularly in the Aucas road, los Zorros road, Pano road, Misahualli road and Ahuano road. To the extent possible, socio-economic data of smallholdings was available in the selected communities; which were previously analyzed in chapter 5 of this study, thus carrying out a similar selection of Kichwa, Shuar and colonist communities.

The selection of case studies was based on a typology of four different forms of smallscale harvesting organization that takes into consideration two basic criteria: the first is the way in which intermediaries and smallholders participate in the harvesting process, and the second is whether the harvesting complies with legal requirements or not. Eight logging operations were selected for information gathering, following the typology in Table 48.

The information was collected in previously validated template sheets. Although the identification of the cases followed the above criteria, the selection of operations depended largely on the willingness of smallholders and intermediaries to provide relevant information. Forest operations were monitored on site for a sequential period of six months between March and August 2012. The monitoring of the cases under study was ended when the timber was placed on the side of the road, where smallholders' participation in the harvesting process ends. 
Table 48. Identified types and number of selected cases ${ }^{a}$

\begin{tabular}{llc}
\hline Type & $\begin{array}{l}\text { Organization of the harvesting } \\
\text { (participation of smallholders and intermediaries) }\end{array}$ & No. of cases \\
\hline 1 & $\begin{array}{l}\text { The intermediary covers PAFSI costs } \\
\text { The intermediary covers harvesting costs } \\
\text { The smallholder does not participate in the harvesting }\end{array}$ & 1 \\
\hline 2 & $\begin{array}{l}\text { The intermediary covers PAFSI costs } \\
\text { The smallholder covers harvesting costs }\end{array}$ & 1 \\
\hline 3 & The smallholder participates in the harvesting & 5 \\
\hline 4 & The smallholder conducts a PAFSI & \\
& The smallholder covers harvesting costs & \\
& The smallholder doesn't follow a PAFSI \\
\end{tabular}

Note: a) The sample depended on the willingness of these actors to participate in the survey.

Source: Own elaboration.

\subsection{Characteristics of timber operations and the actors involved}

Following the typology mentioned above, three formal cases (type 1,2 and 3) and five informal cases (type 4) were established. In general, all operations showed that the main constraints in onsite logging and hauling are the topographical and climatic conditions. Table 49 presents eight cases with their main characteristics. The characteristics of these cases are described below.

- In formal case 1 , timber harvesting was conducted in an indigenous community where a Simplified Forest Harvesting Management Plan (PAFSI, for its acronym in Spanish) had been negotiated with a community member who decided not to participate in the logging and sell instead his standing trees, since he also runs a liquor store. In this sense, the timber intermediary hired two operators and three haulers to take the timber to the side of the road. Land transportation was also arranged by the intermediary, who hired trucks to deposit the timber in Coca and, subsequently, in Huaquillas.

- In formal case 2, harvesting occurred in an individual property owned by a colonist smallholder. The smallholder did not participate in the cutting process due to health problems. For this reason, he sold standing trees instead. The intermediary used three operators and two haulers. He was also in charge of transportation. This intermediary, from the coast, began his business as a transporter-intermediary.
However, later on, he took over the entire harvesting operation.

- Formal case 3 was conducted in an indigenous community led by a smallholder involved in the building sector. He hired temporary staff for the logging and hauling and took care of processing the logging permit through a public forestry advisor of the Ministry of Environment (MAE, for its acronym in Spanish) ${ }^{27}$. Moreover, he covered the costs of land and river transportation to the final destination, Coca.

- Informal case 1 was carried out in an individual property owned by an indigenous family harvesting timber sporadically, since due to selective logging they do not have many valuable species. Input, hauling and labor costs were entirely borne by the smallholder. The timber was sold on the side of the road by a transportationintermediary, who had ordered timber for formwork.

- Informal case 2 was carried out in an individual property owned by a colonist family. The operation was conducted by the smallholder on his own land. This smallholder is also a local sawyer-intermediary. In general, when a smallholder acts as this type of intermediary, he logs small amounts of timber from other lands and sells them to a transportation-intermediary. In the case under study, the person sold formwork timber to the same transportation intermediary who had bought the timber in informal case 1 .

27 In 2011 the Ministry of Environment created the position of public forestry advisor to reduce smallholders' legalization costs. 


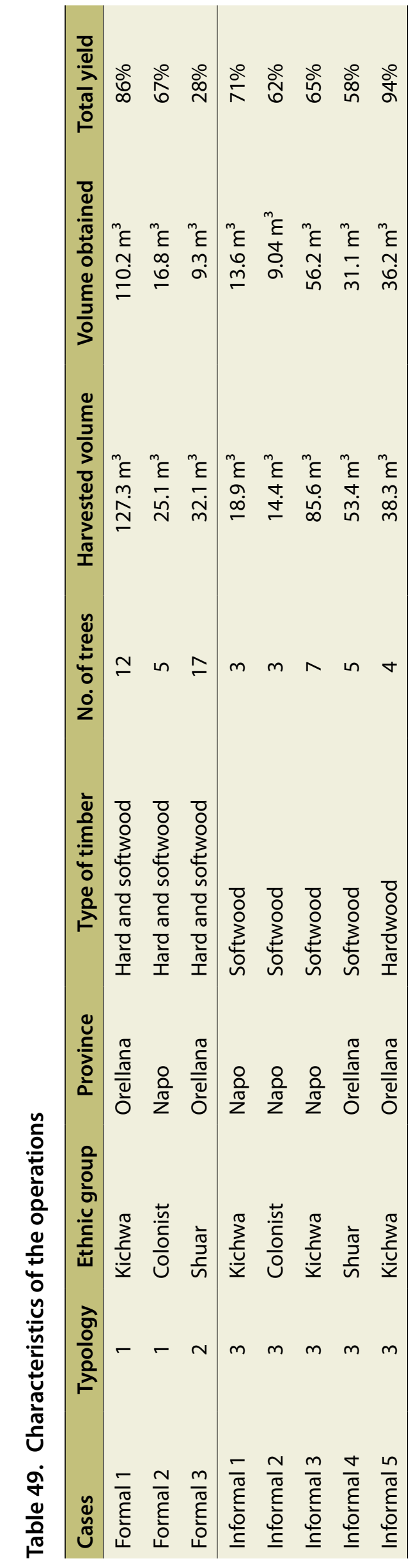

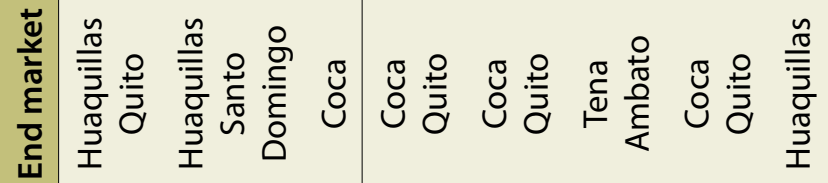

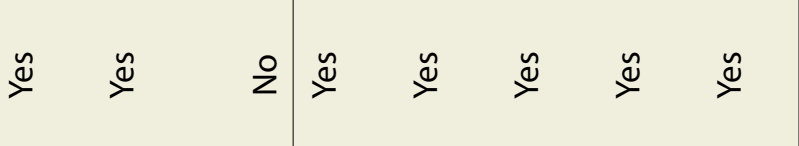

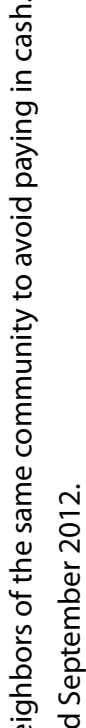

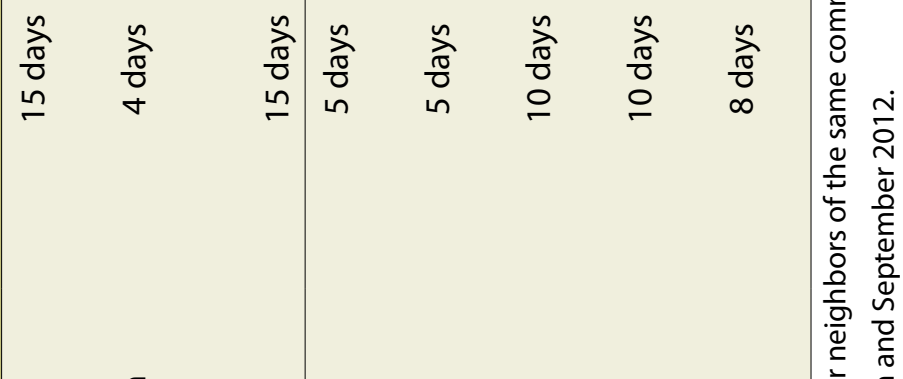

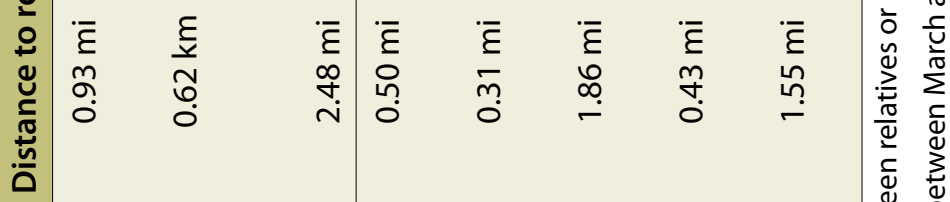

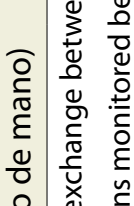

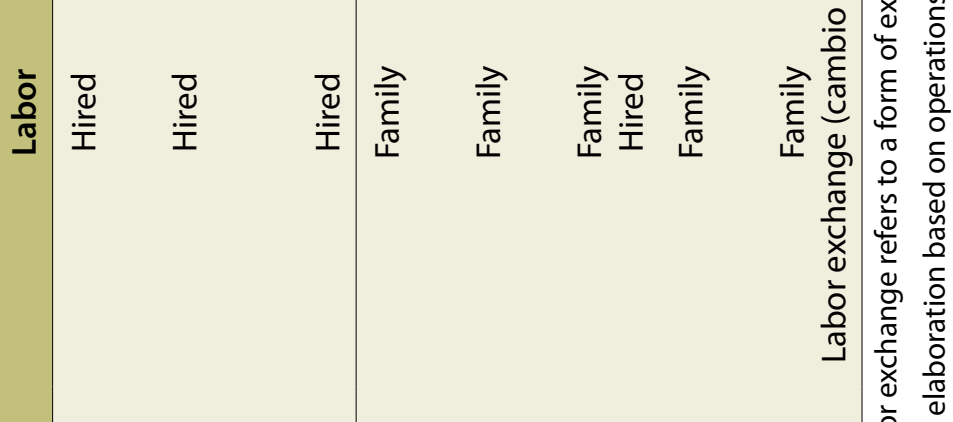

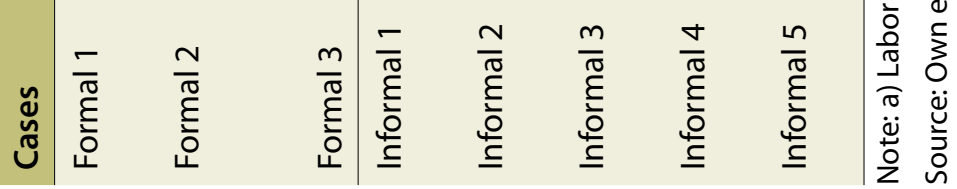


- Informal case 3 was carried out in a property that is only accessible by river. This family harvests timber to sell it in the local market, and uses this income to cover education and food expenses. The smallholder used family labor, especially his wife and children, during timber harvesting and logging. He also hired raft drivers (balseros) to transport the timber downstream to the local market, which brings together a number of transportation-intermediaries every Friday.

- Informal case 4 was carried out in an individual property inside an indigenous community. The transportation-intermediary that had ordered the timber, made an advance payment so that the smallholder could cover the expenses generated from buying oil and chainsaw spare parts. The smallholder harvested with the help of his wife and children, but they hired haulers with mules to transport the timber to the road side.

- Informal case 5 was carried out in a communal forest of an indigenous community. The smallholder requested authorization to harvest four hardwood trees to sell the timber to a timber intermediary who was carrying out a formal operation in the same community. In this case the timber helped complete the volume projected in the legal program, since several trees could not be harvested. The smallholder logged the timber using inputs provided by the intermediary and neighbor labor. Moreover, he hired haulers to transport the timber to the side of the road. He used this income to buy a motorcycle.

\subsection{Legality costs in timber harvesting programs}

According to the estimates in the case studies, the decision to harvest according to regulations depends on smallholders' connections with a broker-intermediary or timber intermediary, depending on order destinations. Likewise, in formal cases 1 and 2, an intermediary covered the approval costs of harvesting programs. Table 50 shows these costs.

Table 50. Costs associated with timber legalization in USD

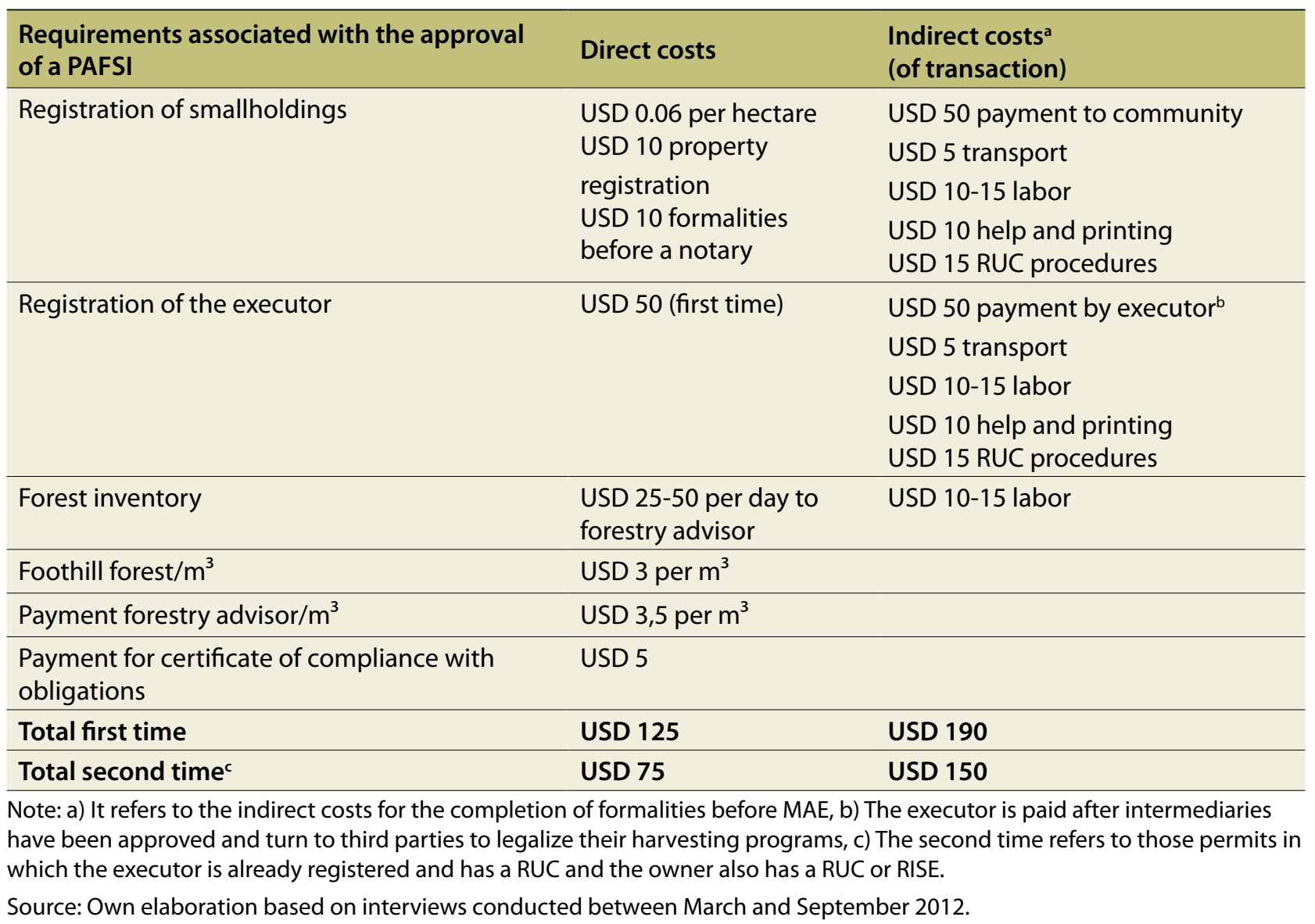


Table 51. Legalization costs in the area under study for different volumes of harvested timber

\begin{tabular}{lcccccc}
\hline Volume & Direct costs & Indirect costs & Foothill forest & Forestry advisor & Total & USD $/ \mathrm{m}^{3}$ \\
\hline $50 \mathrm{~m}^{3}$ & 125 & 190 & 150 & 150 & 615 & 12.3 \\
$100 \mathrm{~m}^{3}$ & 125 & 190 & 300 & 300 & 915 & 9.1 \\
$200 \mathrm{~m}^{3}$ & 125 & 215 & 600 & 600 & 1540 & 7.7 \\
$400 \mathrm{~m}^{3}$ & 125 & 215 & 1200 & 1200 & 2740 & 6.8 \\
\hline
\end{tabular}

Source: Own elaboration based on interviews conducted between March and September 2012.

The costs associated with the legalization process of forest harvesting are divided into two groups. On the one hand, there are direct costs derived from required payments to comply with the Logging and Simplified Forest Management Programs of the Ministry of Environment. On the other hand, there are indirect costs, which do not constitute direct requirements but are necessary to complete administrative procedures. Where forest harvesting was conducted without following authorized programs, transaction costs were minimal, since program development costs were avoided and the intermediary contacted the community directly. Transaction costs covered by timber intermediaries are difficult to quantify. However, Table 50 includes reference figures.

It is estimated that, on average, between 6.8 and 12.3 USD are needed to legalize a cubic meter of timber in the area under study, depending on the logging volume (Table 51). These estimates suggest that the costs of legalizing timber harvesting tend to decrease as the volume of harvested timber increases. According to the intermediaries interviewed in the study in chapter 3, this leads to a preference of legal timber harvesting of at least $100 \mathrm{~m}^{3} /$ sawn timber.

\subsection{Decisions related to timber harvesting, productivity and quality}

The decision made by the smallholders as regards the harvesting of a tree was discussed with them during data collection. In the case of formal harvesting, this decision was generally made by a forestry technician or a forestry advisor, who is in charge of marking the trees to be approved. In the case of informal harvesting, or harvesting that is conducted without formal authorization, this decision is made by the smallholder himself, and sometimes by the chainsaw operator. The main parameter usually taken into consideration is that the selected tree should effectively provide at least 15 wide planks (Approximately $0.5 \mathrm{~m}^{3}$ ). Although this rule was observed in five cases of informal timber logging, this does not mean that only trees of this volume are harvested, but rather that this is the criterion for setting the minimum logging volume. Table 49 shows the average logging volume in the cases analyzed. This criterion assumes that at least this number of logs per tree will cover the costs associated to the harvest operation and that this will generate an income to the smallholder.

There are other factors that determine the volume and species to be harvested, which have to do with the quality of the timber. According to the intermediaries interviewed during logging, there are markets like those of Huaquillas, Quito and Guayaquil that demand good quality timber without mechanical or pathological defects. In addition, the timber should be measured based on buyer requirements. These requirements are possibly due to the fact that some of the timber sent to Huaquillas is sold in international markets (Box 3 in chapter 4), whereas chuncho (Cedrelinga catenaeformis) timber, which is traded in Guayaquil is intended mostly for export after being transformed into doors (Ministerio del Ambiente del Ecuador, 2011).

Smallholders or chainsaw operators pay special attention when cutting and sawing, especially when these operations involve more valuable species, such as colorado, chuncho and arenillo (Erisma uncinatum), to avoid improper cuts or damages. In this sense, they also reject logs with pathological defects ${ }^{28}$ that render timber that is less valuable. These are also logged, despite their

28 A common defect in heartwood is the "knot", which is defined as a kind of eye in the timber. 
lower commercial value, and are considered average quality, provided that they correspond to hard species. Among hired chainsaw operators and smallholders who perform the cutting, the latter prefer to take advantage of "defective" logs, thus diversifying sales through different intermediaries, which only occurs when species with commercial value are involved.

In logging with chainsaw, more waste was registered in formal than informal operations. The difference between the two is related to the time spent during logging and selection. In the first case, a day and a half was spent on average for every softwood tree and two days for every hardwood tree logged. The logging was carried out by experienced chainsaw operators and smallholders. In the second case, which comprises unauthorized or informal harvesting programs, logging took longer; with an average for softwood trees of four days and five days for hardwood trees. Generally, during informal harvesting, smallholders do not devote all their time to this activity, but work in other activities in their smallholdings.

Chainsaw use during harvesting, in terms of efficiency, is currently under debate (Box 4). Usually, and although there is little empirical evidence to support this view, chainsaws are regarded as a low performing tool, thus generating lower income to smallholders (Vásquez, 2011; Vinueza, 2012). Also, large-scale roundwood harvesting would lead to less waste than smallscale harvesting, where timber is mostly sawn with chainsaws in the forest. However, the data analyzed in this study on the trees that generated waste both in logging as sawing $(n=23)$ show that sawing waste is less waste from unharvested logs due to some mechanical or pathological malformation. There is a clear difference between harvesting planks and boards, the latter creating more sawing waste (Table 52).

\section{Box 4. Chainsaw operators in timber harvesting \\ Marco Vinueza, Santiago Alarcón y Amanda Onofa}

In the only census of sawmills, timber industries and depots, carried out by the National Forestry Directorate in 1982-83, it is shown that at that time there were over 500 circular sawmills that were gradually replaced by the chainsaw (Vásquez, 2011). In this sense there is a paradigm according to which chainsaws put more pressure on native forests than mechanized large-scale harvesting operations (ITTO, 2004; Barrantes, 2006; Viteri, 2010). During the past few years the Amazon has become one of the most important sources of extraction of sawn timber. Apart from cutting, the chainsaw is used in the sawing of timber measured for personal use or to enter the production chain. A chainsaw operator earns around 40 USD per day, sawing 25 simple planks ( $\left.1 \mathrm{~m}^{3} / \mathrm{day}\right)$, for a period of 21 consecutive days, depending on the distance of the forest, the number of trees and legal status. When they are hired on a work day basis and not according to the number of obtained pieces, the daily salary ranges between 25 and 35 USD. This exceeds the basic salary of the country, which makes this activity attractive. The chainsaw operators tend to replace their machinery purchased in installments in local stores in Puyo, Tena and Coca, the tendency being to have smaller machines with faster motors, permitting to cut pieces of higher quality. In general, the chainsaw operators think that they do not have the necessary training to improve the work standards. There are chainsaw operators who are considered "professionals" when they dominate the cutting of pieces, create less waste and work fast, and they are the most demanded to work in shipments to markets that demand quality such as Quito, Guayaquil and Huaquillas.

Table 52. Differences between average waste of cutting and sawing

\begin{tabular}{lcc}
\hline $\mathrm{n}=\mathbf{2 3}$ trees & Average waste due to logs with malformations (in $\mathrm{m}^{\mathbf{3}}$ ) & Average waste from sawing (in $\mathrm{m}^{\mathbf{3}}$ ) \\
\hline Boards & 3.48 & 2.95 \\
Plank & 2.19 & 0.35 \\
\hline
\end{tabular}

Source: Own elaboration based on operations monitored between March and September 2012. 
In terms of timber yield percentages, there are variations between species and it is difficult to demonstrate a trend, as shown in table 53. These yields, as already mentioned, vary according to the product to be harvested.

\subsection{Costs and benefits of small-scale timber harvesting}

It is difficult to determine the costs and benefits in small-scale timber harvesting, since as a result of various factors, fixed costs of this harvesting show relatively large variation and are associated with specific conditions in each operation, such as distance from markets, smallholder participation, type of labor, distance to the smallholding and available species, among others. Each of the selected cases has unique characteristics, thus making it difficult to establish clear trends in terms of operation costs and benefits.

It is important to highlight that cost variability is relatively high for different forest operations, due to the various dimensions of the harvested products. To facilitate the comparison, values obtained are presented in $\mathrm{m}^{3}$ and are expressed in units such as boards, thick and wide planks (Table 55).

There are three variable factors which generally have a higher impact on the costs and benefits of smallscale timber harvesting; these are: 1) smallholder participation in logging, 2) the average distance to the road, and 3) the type of timber (hard or soft) that is being harvested. These factors mainly affect the cost of labor and materials (Table 49).

Table 53. Average yield in studied species

\begin{tabular}{lccc}
\hline Species & $\begin{array}{c}\text { Initial volume } \\
\mathbf{m}^{3}\end{array}$ & $\begin{array}{c}\text { Final volume } \\
\mathbf{m}^{3}\end{array}$ & Yield \\
\hline Arenillo (Erisma uncinatum) $\left(^{*}\right)$ & 12.80 & 11.50 & $89.9 \%$ \\
Caguapanela (Nectandra sp.) $\left(^{*}\right)$ & 1.81 & 0.15 & $8.4 \%$ \\
Canelo (Ocotea spp.) & 2.30 & 0.78 & $33.8 \%$ \\
Ceibo (Ceiba insignis) & 13.03 & 7.76 & $59.6 \%$ \\
Chuncho (Cedrelinga catenaiformes) $\left(^{*}\right)$ & 4.29 & 3.88 & $90.6 \%$ \\
Coco (Virola spp.) & 1.21 & 0.36 & $29.7 \%$ \\
Copal (Dacryodes peruviana) & 10.30 & 6.66 & $64.6 \%$ \\
Cruz caspi (Mauriri sp.) & 1.69 & 0.21 & $12.4 \%$ \\
Cuero de sapo (Parinari sp.) & 1.82 & 1.75 & $96.0 \%$ \\
Doncel, sangre de gallina (Otoba spp.) & 6.99 & 6.34 & $90.7 \%$ \\
Guarango (Acacia glomerosa) & 3.56 & 1.56 & $43.9 \%$ \\
Guayabillo (Terminalia oblonga) & 3.50 & 1.89 & $54.0 \%$ \\
Guayacán (Tabebuia guayacan) $\left(^{*}\right)$ & 4.19 & 0.72 & $17.2 \%$ \\
Manzanofino (Guarea kunthiana) $\left(^{*}\right.$ ) & 10.75 & 9.06 & $84.2 \%$ \\
Mascarey (Hyeronima sp.) & 7.69 & 2.47 & $32.1 \%$ \\
Peine de mono (Apeiba membranácea) & 0.85 & 0.70 & $81.7 \%$ \\
Pigüe (Piptocoma discolor) & 1.08 & 0.99 & $91.1 \%$ \\
Sande (Brosimun sp.) & 11.25 & 5.34 & $47.5 \%$ \\
Sangre (Otoba sp.) & 2.53 & 0.26 & $10.4 \%$ \\
Sapote (Sterculia sp.) & 9.67 & 6.21 & $64.2 \%$ \\
Tamburo (Vochysia spp.) & 9.57 & 9.12 & $95.4 \%$ \\
\hline No: Species & & \\
\hline
\end{tabular}

Note: Species marked with an * belong to hardwood species or species with high commercial value.

Source: Own elaboration based on operations monitored between March and September 2012. 
Table 54. Average costs and sale price of harvested species (in USD $/ \mathrm{m}^{3}$ )

\begin{tabular}{|c|c|c|c|c|}
\hline \multirow{2}{*}{ Species $^{\mathrm{a}}$} & \multicolumn{2}{|c|}{$\begin{array}{l}\text { With authorization } \\
\text { (average based on } 3 \text { cases) }\end{array}$} & \multicolumn{2}{|c|}{$\begin{array}{c}\text { Without authorization } \\
\text { (average based on } 5 \text { cases) }\end{array}$} \\
\hline & Costs $\mathrm{m}^{3}$ & $\begin{array}{l}\text { Prices on the } \\
\text { side of the road }\end{array}$ & Costs $\mathrm{m}^{3}$ & $\begin{array}{l}\text { Prices on the } \\
\text { side of the road }\end{array}$ \\
\hline Arenillo (Erisma uncinatum) $\left(^{*}\right)$ & 47 & 40 & 49 & 140 \\
\hline Caguapanela (Nectandra sp.) $\left(^{*}\right)$ & 106 & 64 & & \\
\hline Canelo (Ocotea spp.) & 96 & 192 & & \\
\hline Ceibo (Ceibainsignis) & 44 & 67 & 32 & 53 \\
\hline Chuncho (Cedrelinga catenaiformes) $\left(^{*}\right)$ & 76 & 133 & 75 & 192 \\
\hline Coco (Virola spp.) & 101 & 64 & & \\
\hline Copal (Dacryodes peruviana) & & & 13 & 40 \\
\hline Cruz caspi (Mauriri sp.) & 139 & 64 & & \\
\hline Cuero de sapo (Parinari sp.) & 128 & 64 & & \\
\hline Doncel (Otoba spp.) & 38 & 50 & 54 & 58 \\
\hline Guayabillo (Terminalia oblonga) & 90 & 70 & 34 & 40 \\
\hline Guarango (Acacia glomerosa) & 45 & 50 & & \\
\hline Guayacán (Tabebuia guayacan) (*) & 82 & 256 & & \\
\hline Manzano fino (Guarea kunthiana) (*) & & & 21 & 168 \\
\hline Mascarey (Hyeronima sp.) & & & 41 & 20 \\
\hline Peine de mono (Apeiba membranácea) & 99 & 64 & & \\
\hline Pigüe (Piptocoma discolor) & & & 32 & 60 \\
\hline Sande (Brosimun sp.) & 104 & 64 & 33 & 61 \\
\hline Sangre (Otoba sp.) & 51 & 36 & & \\
\hline
\end{tabular}

Note: a) These are the most representative species found in the cases analyzed; many are repeated, so an average was chosen; (b) Income from sales suggested by the intermediary, forestry advisor or transporter depending on final destination of the timber. Species marked with an ${ }^{*}$ belong to hardwood species or species with a high commercial value.

Source: Own elaboration based on interviews conducted between March and August 2012.

Table 54 shows the difference in costs and revenues between soft, semi-hard and hard species that were harvested in the eight timber operations under study. Hard species like colorado, chuncho, arenillo and copal, which generate higher revenues per cubic meter, were sold in the Huaquillas and Quito markets. Soft species like the doncel, guarango,sapote ceibo and tamburo have lower values, but are well sold in local markets, as well as external markets like Ambato and Quito, especially in the building sector.

\subsubsection{Operation costs}

Higher costs correspond to labor, whereas lower costs correspond to payments for the legalization of harvesting procedures and input use. However, the latter constitute the main constraint for smallholders engaged in formal operations, since these operations demand a higher logging volume to reduce the costs per cubic meter, as already indicated in table 50 in this chapter. In informal harvesting operations, labor costs become a key factor for larger logged volumes. In this sense, 15 trees was the highest number of harvested trees registered in an informal operation ${ }^{29}$, which was carried out by a sawyer-intermediary. However, the trend in the cases analyzed shows that informal harvesting operations present, on average, three trees/logging operation.

29 This informal harvesting operation was not analyzed in this study, since at the time of the field visit the timber had already been logged and transported. However, the smallholder provided details about the logging process. 
It is interesting to note that the labor used for hauling was considered to be the most expensive part of the operation in the interviews to smallholders. To avoid this cost, especially in informal operations, women participate more actively in forest harvesting, particularly in the case of Kichwa families (Box 5).

\subsection{Income distribution between smallholders and intermediaries}

Intermediaries' income is higher than smallholders', regardless of whether forest operations are duly authorized or not. In formal case 1 and informal case 4, costs are higher than smallholders' income. In the first case, the highest costs did not represent a loss for the smallholder, since these were absorbed entirely by the intermediary, who paid the standing timber to the smallholder. In the second case, however, the smallholder lost money due to several factors, including the selected (softwood) species and high labor and hauling costs derived from the long distance between the harvested forest and the main road (Table 49).

In all eight cases, there is not enough information to establish that formal ones represent a higher income per $\mathrm{m}^{3}$ to the smallholder than informal cases. Higher income is closely related to harvested species, especially in the case of hardwood species, as shown in Tables 54 and 55. In this sense, smallholders are conditioned by forest quality and also by orders from intermediaries, who usually request specific species.

In the cases analyzed, smallholders and intermediaries obtained, in general, higher income than the total costs per operation. In the case of authorized harvesting operations, the intermediary's income between $50 \%$ and $110 \%$

\section{Box 5. Participation of women in forest harvesting activities: Invisible labor-Kichwa women} Elena Mejía, Liliana Vásquez.

One of the principal policies proposed in the National Plan for Good Living of Ecuador is to guarantee equal conditions and opportunities for the full participation of women, especially in the access to natural resources (Núñez, 2009; SENPLADES, 2009). In Ecuador, almost three quarters (74\%) of producers and owners of production units are men, even though women constitute $42 \%$ of the active agricultural population (III National Agricultural Census, 2000, INEC). In 18,6\% of rural households women have the exclusive economic responsibility. The rural women are responsible for the cultivation of most food and tend to combine their productive tasks in the smallholding or a family business with taking care of their families; their contribution, apart from being non-remunerated, lacks visibility (FENOCIN; CNC, 2012; Nino, 2010).

In February and March 201320 interviews with women and 10 with men were carried out in five Kichwa communities where the logging operations were monitored in order to understand the access of these women to land tenure and the decision making concerning forest use as well as the distribution of timber income. The results indicate that the Kichwa women participate in the timber extraction process together with men; their activities range from cooking and taking food to the forest to carrying planks and boards on their shoulders, transporting mules, helping in the planning and marking the cuts in the logs and carrying materials. The women do not receive a compensation for their help in forest activities; neither do they participate in the selling of the timber, nor the negotiation with the intermediary. The men consider the help of the women indispensable, due to the fact that it enables reducing costs on additional staff in timber harvesting, especially in informal logging. The access to forest and its exploitation is similar for both genders, but the products are differentiated. The timber is masculine while annual crops like cassava and banana are feminine; the perennial crops such as cacao are of both genders. The knowledge of the property is the same for both genders and different generations, meaning that men as well as women of different ages know the assets of their forests and farms. However, land tenure presents analogous levels between the two genders; the Kichwa women hope to obtain access to their husbands' lands, but in the five communities visited the women were obtaining ownership rights due to inheritance from their parents or for being widowed. In the areas under study it was observed that the land tenure is associated with the management of forest for harvesting and marketing. 
Table 55. Average costs and sale prices of harvested species in the case studies (in USD/product)

\begin{tabular}{|c|c|c|c|c|c|c|}
\hline & \multicolumn{3}{|c|}{ With authorization ${ }^{\mathrm{a}}$} & \multicolumn{3}{|c|}{ Without authorization $^{b}$} \\
\hline & $\begin{array}{l}\text { Smallholding } \\
\text { income }\end{array}$ & $\begin{array}{c}\text { Costs } \\
\text { unit }\end{array}$ & $\begin{array}{c}\text { Net } \\
\text { Income }\end{array}$ & $\begin{array}{l}\text { Smallholding } \\
\text { income }\end{array}$ & $\begin{array}{c}\text { Costs } \\
\text { unit }\end{array}$ & Net income \\
\hline \multicolumn{7}{|l|}{ Table } \\
\hline Arenillo & & & & 2.6 & 1 & 1.6 \\
\hline Ceibo & 0.8 & 0.5 & 0.3 & 0.8 & 0.5 & 0.3 \\
\hline Doncel & & & & 1.1 & 1.4 & -0.3 \\
\hline Guarango & 0.6 & 0.9 & 0.3 & 0.6 & 0.5 & 0.1 \\
\hline Sapote & & & & 1 & 0.6 & 0.4 \\
\hline \multicolumn{7}{|l|}{ Plank $^{\mathbf{d}}$} \\
\hline Manzano fino & & & & 4.3 & 0.9 & 3.4 \\
\hline Chuncho & 6 & 2.4 & 3.6 & & & \\
\hline Arenillo & 2 & 2.3 & -0.3 & & & \\
\hline Guayacán & 8 & 2.6 & 5.4 & & & \\
\hline Canelo & 8 & 3 & 5 & & & \\
\hline Tamburo & 1.8 & 2.5 & -0.7 & & & \\
\hline Cuero de sapo & 2 & 4.0 & -2 & & & \\
\hline Caguapanela & 2 & 3.3 & -1.3 & & & \\
\hline Cruz caspi & 2 & 4.3 & -2.3 & & & \\
\hline Guabillo & 2 & 3.2 & -1.2 & & & \\
\hline Peine de mono & 2 & 3.1 & -1.1 & & & \\
\hline Sande & & & 0 & 0.5 & 1.6 & -1.1 \\
\hline Coco & 2 & 3.2 & -1.2 & & & 0 \\
\hline Copal & 1.2 & 2.6 & -1.4 & 1.2 & 0.4 & 0.8 \\
\hline Sapote & 2 & 3.2 & -1.2 & 1.2 & 0.5 & 0.7 \\
\hline Guarango & 2.5 & 3.1 & -0.6 & & & 0 \\
\hline Doncel & 2 & 1.9 & 0.1 & 1.2 & 0.5 & 0.7 \\
\hline Mascarey & & & & 1 & 2 & -1 \\
\hline \multicolumn{7}{|l|}{ Thick plank } \\
\hline Chuncho & 8 & 4.5 & 3.5 & & & \\
\hline Guayabillo & 1.8 & 2.7 & -0.9 & & & \\
\hline
\end{tabular}

Note: a) The intermediary assumes the costs of production, b) The smallholder assumes the costs of production, c) Timber measures are $7.87 \mathrm{ft} \times 0.82 \mathrm{ft} \times 0.98 \mathrm{in}$, and $13.12 \mathrm{ft} \times 0.82 \mathrm{ft} \times 0.98 \mathrm{in}, \mathrm{d})$ Timber measures are $7.87 \mathrm{ft} \times 0.82 \mathrm{ft} \times 19.69 \mathrm{in}$ and 13.12 $\mathrm{ft} \times 0.82 \mathrm{ft} \times 19.69 \mathrm{in}, \mathrm{e})$ Timber measures are $7.87 \mathrm{ft} \times 0.82 \mathrm{ft} \times 3.94 \mathrm{in}$.

Source: Own elaboration based on interviews conducted between March and August 2012.

of the total amount invested per $\mathrm{m}^{3}$. As previously discussed, benefits also depend on harvested species and smallholder participation at this stage. In general, formal harvesting is focused on logging of hardwood or a combination of hardwood, semi-hardwood and softwood. According to intermediaries, a legal softwood harvesting program would not be beneficial.
In the formal case in which the smallholder did not participate (formal case 1), income was 30\% lower than if he had participated in the logging, as evidenced by detailed income per case in Figure 15. In this sense, smallholder participation in logging increases timber value, since logs have an added value derived not from the value of standing trees but from the labor used by the smallholder. 


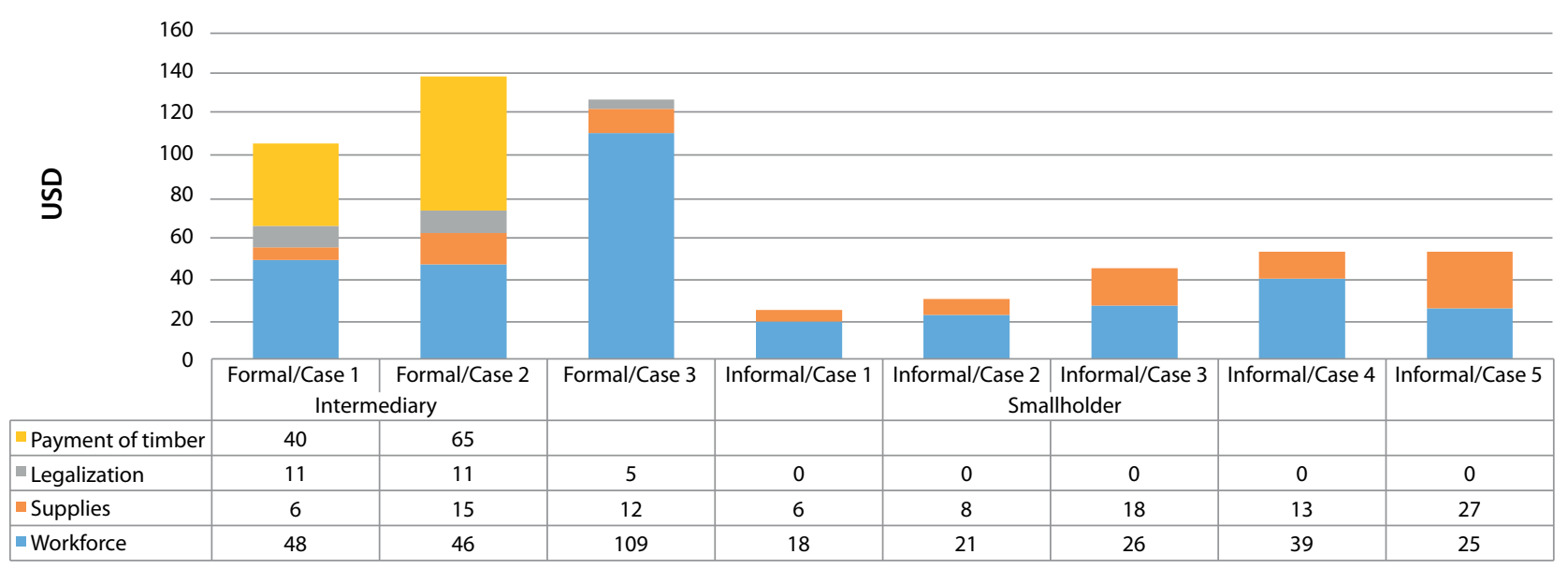

Figure 15. Distribution of costs per cubic meter by item and smallholders' share for eight case studies of small-scale timber harvesting with and without PAFSI (in USD). Based on interviews carried out between March and August 2012.

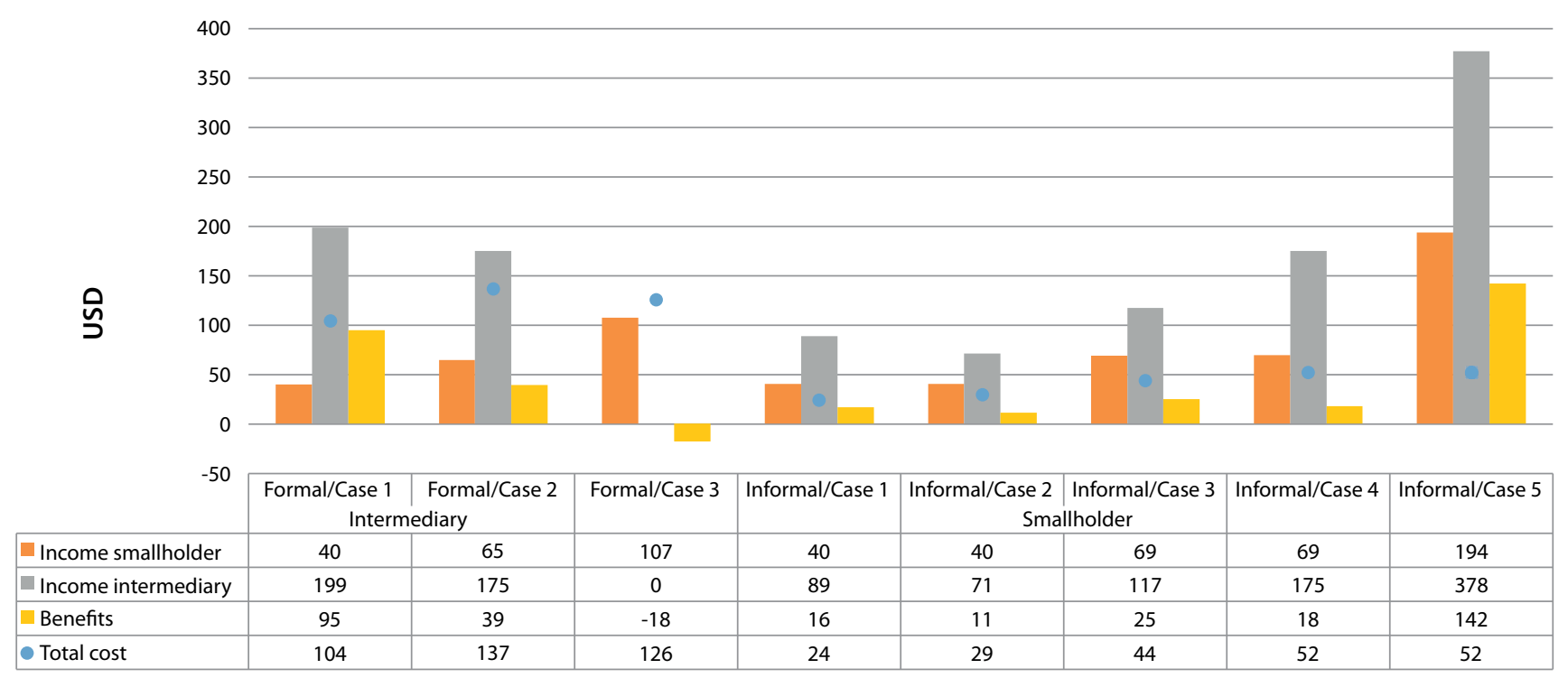

Figure 16. Difference of income and costs between formal and informal artisanal operations with smallholder or intermediary intervention $\left(\mathrm{USD} / \mathrm{m}^{3}\right)$. Personal compilation based on field data gathered between March and August 2012.

\subsubsection{Analysis of benefit distribution among actors in the harvesting process}

In this section, details are provided on the income obtained by the actors involved in the harvesting process. In addition to smallholders and intermediaries, haulers and chainsaw operators are also included. In Figure 16, there is clear evidence that it is intermediaries that obtain greater benefits, regardless of whether the operation is duly authorized or not regardless of the smallholder's participation in the logging. This is also shown in Figure 17. Unlike the income analysis, benefits show the net profit that actors obtain after cost deduction related to their activity. For example, in the case of chainsaw operators, costs from chainsaw repair and chain replacement during harvesting are also included. Usually, chainsaw operators obtain moderate income from logging, despite the widespread idea that they are the ones who benefit the most from this operation. Therefore, 


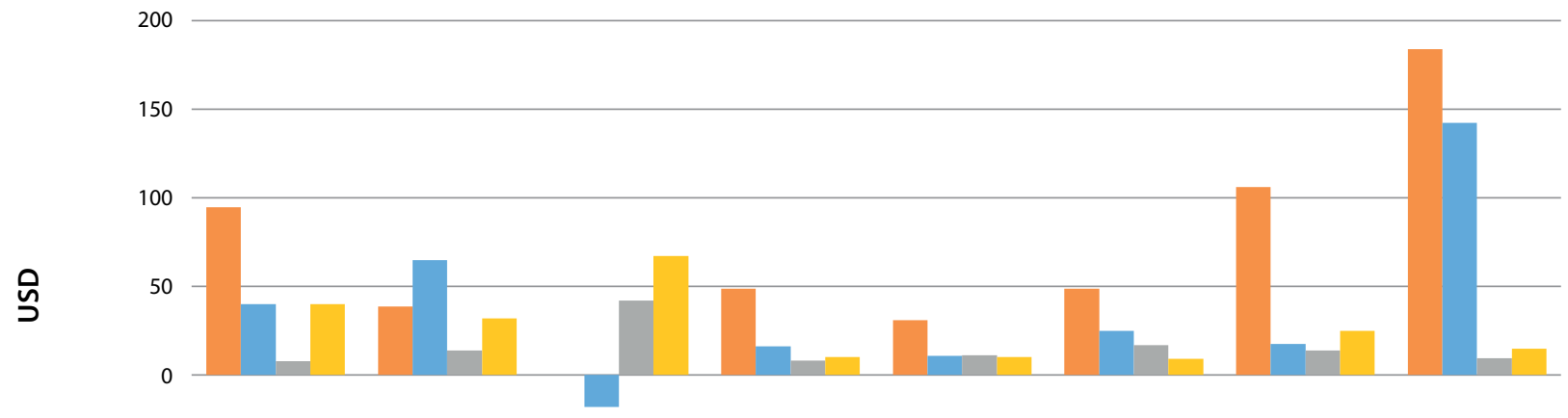

\begin{tabular}{|c|c|c|c|c|c|c|c|c|}
\hline-50 & $\begin{array}{r}\text { Formal/Case } 1 \\
\text { Interm }\end{array}$ & $\begin{array}{l}\text { Formal/Case } 2 \\
\text { ediary }\end{array}$ & Formal/Case 3 & Informal/Case 1 & $\begin{array}{r}\text { Informal/Case } 2 \\
\text { Small! }\end{array}$ & $\begin{array}{l}\text { Informal/Case } 3 \\
\text { holder }\end{array}$ & Informal/Case 4 & Informal/Case 5 \\
\hline Intermediary & 95 & 39 & & 49 & 31 & 49 & 106 & 184 \\
\hline Farmer & 40 & 65 & -18 & 16 & 11 & 25 & 18 & 142 \\
\hline Hauler & 8 & 14 & 42 & 8 & 11 & 17 & 14 & 10 \\
\hline Chainsaw operator & 40 & 32 & 67 & 10 & 10 & 9 & 25 & 15 \\
\hline
\end{tabular}

Figure 17. Distribution of benefits among harvesting actors $\left(\mathrm{USD} / \mathrm{m}^{3}\right)$. Personal compilation based on field data gathered between March and August 2012.

it is important to distinguish between a sawyerintermediary and a simple sawyer.

In the case of formal harvesting by intermediaries, income is higher for smallholders than in informal operations, except in informal case 5 , in which only hardwood species were harvested. In the latter case, the profit obtained by the smallholder was $53 \%$ higher than in formal cases, which confirms that harvested species are more important than the legality of logging itself, in terms of the level of harvesting benefits. However, hard species can only be ordered by intermediaries who can transport the timber. Otherwise, transport to the city for its subsequent trading is difficult for smallholders, since many times the timber is not sold locally but is intended for other provinces.

Timber prices per cubic meter paid to smallholders and intermediaries show differences between 20\% and $60 \%$, depending on the species and the market. The percentage of income is more proportional between smallholders and intermediaries when harvested species are commonly traded hardwood species. The gap between these groups is greater when it comes to the harvesting of softwood species. The fact that some forest harvesting operations are conducted informally or without authorization, does not seem to affect the final income, compared to those which are authorized. These differences are accounted for by the species that are harvested (see again Tables 54 and 55).
The intermediaries assume the costs of authorized Forest Harvesting Programs, whereas smallholders assume the costs derived from informal harvesting, except in formal case 3 , in which smallholders covered the costs of the program. In the second group, informal harvesting operations were marked by losses in the processing of softwood species into boards, as is the case with the doncel (Table 55). However, if the total harvested volume is taken into consideration, logging in informal cases reported income, since other valuable species offset the losses.

During the discussion along the fieldwork, smallholders were aware of such losses. However, they continued logging operations to comply with the orders of the different intermediaries, and to obtain income to buy provisions and gas for the next logging operation.

\subsection{Comparison of smallholders' benefits}

There are several studies that analyze the costs and benefits of different harvesting methods with the aim of determining the best alternative to obtain income from forest management (Mederski, 2006; Bauch, et al., 2009; Spinellia, et al., 2099; Ghajar y Najafi, 2012). Studies on small-scale timber harvesting indicate that, in general, smallholders are the ones who benefit the least (Hetsch, 2004; 
Díaz and Gatter, 2004; Espinoza, 2005). The case studies presented here also show this tendency with respect to intermediaries, who have more efficient harvesting methods to achieve economies of scale, thus resulting in higher profits. Other actors, like chainsaw operators and haulers also obtain higher benefits than smallholders in terms of harvesting intensity. This link was also observed in Napo by Hetsch (2004) in Pastaza and Schlotzhauer (2012). However, in cases 2 and 3, the use of family labor reduces logging and hauling costs.

As regards to formal and informal timber harvesting, in eight of the cases analyzed there is no clear tendency suggesting that formal harvesting generates more income for smallholders. Rather, it is traded species and end markets that determine price differences and, consequently, the profits. In this sense, the studies carried out by Gatter et al. (2005) also concluded that tree species are crucial for smallholders. However, some transportation intermediaries have no special interest in the value of the species, because they take advantage of the return journey after having sold other products.
Timber harvesting requires intensive labor. This is the reason why it represents the highest costs and is also a limiting factor in timber extraction. In the informal cases analyzed, smallholders cut the timber using family labor, especially female, since there is no higher opportunity cost for this type of labor. In this case, low prices for timber or raw materials, in particular softwood species of low economic value, are compensated by family labor. This explains why intermediaries conducting formal harvesting operations are not interested in legalizing softwood species and prefer, instead, to purchase this type of timber in informal markets. Southgate (2000) and Sierra (2001) reached the same conclusion.

In general, markets determine the demand for species to be bought and then harvested by smallholders, as well as logging quality and speed. The best profit scenario for smallholders is yearround harvesting of species with higher market value, as well as smallholder participation in formal logging operations. 


\section{Conclusions}

Forests, mainly timber, provide an important source of income for the households in the area under study in the Ecuadorian Amazon. Like other households around the world (Mamo et al., 2007; CIFOR, 2011; Angelsen et al., 2011), the households analyzed in Napo and Orellana depend to some extent on money in cash from timber sales. Harvesting is carried out mainly in primary forests and agroforestry systems. This indicates that families own lands with native forests and trees within the intervened areas. Both are equally important for the family economy, since they are adapted to the different biophysical and political situation of the Amazon.

When comparing timber harvesting in Napo and Orellana, which are our focus of interest, we note that timber income in Napo comes from agroforestry areas, since these are older settlements where more intervention has taken place. Timber in Orellana, however, comes mainly from native forests, since these are more recent settlements which are characterized by larger and relatively less harvested forest areas. The difference between the two provinces is the area for land uses and the prevalence of valuable species which native forests still preserve compared to agroforestry areas. Although in varying degrees, both types of land use generate income for local households.

Timber from the Amazon supplies mainly the expanding urban domestic markets, although there is a part of the total volume that is intended for international markets. However, there are no reliable data on timber exports. The findings of this study suggest that marketing is structured through relatively complex intermediary networks, which operate through formal and informal mechanisms and aim to address the quantity and quality demands in the orders from different industry sectors. The domestic timber market, at least the one producers and intermediaries in the Ecuadorian Amazon are connected to, is led by large-scale depots that stock timber; particularly, species of high commercial value. This concentration of demand had already been analyzed by previous studies in Ecuador (see, for example, Sierra, 2001; Wunder, 2005 and Middleton, 2007). This suggests that the composition and structure of the domestic timber market has experienced few changes in recent years.

In the light of the increasing domestic demand for timber, the State has sought to improve the control of timber transport from origin to destination through SAF, which has been a central issue in forestry policies. Nowadays, the implementation of more rigorous control due to various irregularities in the way this system was implemented has increased the time and costs associated with obtaining a logging or harvesting permit. This situation has also been discussed in other studies (see FAO, 2012 and Blandinieres et al., 2013). However, there is evidence that payments made for foothill forests together with permit costs have interfered with the harvesting and transport of small legal volumes of timber. Thus, smallholders and intermediaries prefer to trade these volumes informally. Volumes greater than $50 \mathrm{~m}^{3} /$ sawn timber are harvested by intermediaries that overcome these barriers precisely by reducing time and economic costs with larger logging volumes.

The persistence of informal harvesting, as well as its potential consequences in the long-term preservation of native forests in the Amazon, has made the State and different civil society actors maintain a relatively strong protection discourse. Despite all efforts to preserve these forests, both through regulations and control systems, there is still interest among indigenous and colonist smallholders in trading small volumes of timber of high commercial value, as we have already 
discussed, generally through informal trading with intermediaries. A significant aspect of this type of behavior is that this type of arrangement empowers smallholders and fosters more equitable profit distribution with the intermediaries. In the case of formal harvesting, producers prefer to log themselves and let the intermediary cover the costs associated with permits, inputs and hauling, so that logging generates a higher income. In this case, legality costs are a problem for those who harvest small volumes of timber, whereas larger volumes are legalized through intermediaries.

In general, benefit negotiation and distribution in the case of logging in the Amazon has been perceived as unfair, especially for smallholders who cannot separate from intermediaries and sell timber directly to different markets (Gatter and Romero, 2005; Añazco, et al., 2010; Palacios and Malessa, 2010; Ministerio del Ambiente del Ecuador, 2011; Schlotzhauer, 2012). The findings in this research suggest that benefit distribution is closely linked to the negotiation between smallholders and intermediaries. This is a challenge for many smallholders due to various factors, including price information, operation costs and market access. Moreover, these findings show that negotiations between smallholders and intermediaries may be trustworthy or not. Both actors are subject to financial loss in cases of a breach of verbal agreements. In the case of intermediaries, this is due to failure to meet logging times, whereas in the case of smallholders, due to non-payment. Negotiations between the parties are fairer when they already know each other and the smallholders understand the agreed prices.

It is thought that sawn timber is cut more inefficiently than in larger mechanical harvesting operations (Wit et al., 2010; Vásquez, 2011; Pokorny et al., 2012). Our findings indicate that, due to uncertainty as regards to timber quality in a given forest, it is difficult to determine whether the productivity of an operation depends on the logging or on pre-existing pathological or mechanical timber damage. It is evident that intermediaries and smallholders put pressure on species of higher commercial value (semihardwood and hardwood species), as they facilitate to cover the costs of legalization as well as offer an opportunity to earn more with a lower investment of resources. In this regard, when formal systems are assessed, it is impossible to assert that they would be more sustainable than informal systems, since both prefer high commercial value timber. Besides, income is not reinvested in improving availability of the harvested species, but rather in generating more informal and formal logging operations.

Harvesting strategies are characterized by being led by smallholders in both provinces and partly by intermediaries in Orellana (slightly less than half). These strategies are adapted according to the internal characteristics of the households. The exclusive participation of intermediaries in harvesting operations mainly indicates that households have limited access to funding to conduct these harvesting operations; especially of large volumes. As regards to transaction cost problems due to asymmetrical information and bargaining power, these do not differ from the harvesting strategies adopted by households. That is, this is a problem that all smallholders face in both provinces.

It is evident that there is income diversification in both provinces, both in colonist and indigenous households. Although work outside the smallholding is the main source of income, the income generated by the agricultural sector is considered the main strategy used in many households. Forest income represents, on average, $16 \%$ of total household income in both provinces, and it contributes mainly to meet their needs, thus creating liquidity for the family economy. The factors that positively affect the dependence on forest income are the ethnic group (colonists and indigenous people), asset possession (chainsaws) and distance to the main town. However, income from agriculture and work outside the smallholding, as well as the location (province), has a negative effect on the dependence on forest income. These findings support the results in the cited literature. It was found that households adopt conservation strategies in their smallholdings by planting species of economic interest for them.

In short, this work brings together different perspectives of timber harvesting from the point of view of forest users. The forest governance scheme is based on the vertical imposition of regulations on smallholders and indigenous people, who find it difficult to adapt to required practices, which constitutes a barrier to the approval of forest harvesting plans. In general, intermediaries have 
managed to overcome these barriers by using different mechanisms, legal and illegal, to meet the orders from buyers in the cities. For smallholders, there is a gap between what they can produce informally on their own and what they can produce formally with the help of an intermediary. This proves that, in order to achieve legality, it is important to meet the needs of capital and technical know-how.

In order to overcome the difficulties faced by local users, mainly smallholders and indigenous peoples, greater efforts are needed to adjust regulations to better adapt them to the needs and interests of these actors. In addition, it is necessary to rethink the incentive and funding system for small-scale harvesting operations, possibly giving privilege to long-term extractions of lower volumes in native forests and agroforestry systems; since this seems to be the option that better suits smallholders' preferences. As a complementary action line, it is important to explore incentive strategies to support forest reforestation and restoration activities by smallholders including valuable species of interest to smallholders, which could generate or maintain forest income in the future.

Since forests tend to degrade over time, better policies and incentives are needed, either to improve the benefits obtained by smallholders through better use of their forest resources or to adopt strategies for a more sustainable forest management. However, these policies should look beyond the smallholdings towards the market networks that shape smallholders' decision making. 


\section{References}

Adhikari B, Di Falco S and Lovett, JC. 2004. Household characteristics and forest dependency: evidence from common property forest management in Nepal. Ecological Economics, Volume 48, pp. 245- 257.

Angelsen A and Kaimowitz D. 1999. Rethinking the Causes of Deforestation: Lessons from Economics Models. The World Bank Research Observer, 14(1), p. 73-98.

Angelsen A, et al. 2011. Environmental income and rural livelihoods: global-comparative assessment. In: Wye Global Conference.

Ańazco M. Morales M, Palacios W and Vega E. 2010. Sector Forestal Ecuatoriano: propuestas para una gestión forestal sostenible. Serie Investigación y Sistematización No 8, Programa Regional, Quito, Ecuador: ECOBONA-INTERCOOPERATION.

Banco Central del Ecuador, 2012. Estadisticas macroeconómicas, Quito: BCE.

Barbieri A, Carr D and Bilsborrow R. 2009. Migration within the Frontier: The Second Generation Colonization in the Ecuadorian Amazon. Population Research and Policy Review, Issue 28, pp. 291-320.

Barrantes GCHVM. 2006. El Bosque En El Ecuador Una Visión Transformada Para El Desarrollo y La Conservación., Quito.

Barrett C. 2008. Smallholder market participation. Concepts and evidence from eastern and southern Africa. Food Policy, Volume 33, pp. 299-317.

Bauch SC, Amacher GS and Merry FD. 2009. Costs of harvesting, transportation and milling in the Brazilian Amazon: Estimation and policy implications. Forest Policy and Economics, Volume 9, p. 903-915.

Bilsborrow RE, Barbieri AF. and Pan W. 2004. Changes in Population and Land Use Over Time in the Ecuadorian Amazon. Acta Amazónica, 34(4), pp. 635-647.
Blandinieres JP, Betancur L, Maradei D and Saraiva GP. 2013. Timber Trade Flows within to and from South America, Szkolna: EPDR.

Boltz F, Holmes TP and Carter DR. 2003. Economic and environmental impacts of conventional and reduced-impact logging in Tropical South America: a comparative review. Issue 5.

Brown D, et al. 2009. Legal Timber: Verification and Control in the Forest Sector, London: ODI.

Chommitz KM. 2007. At Loggerheads? Agricultural Expansion, Poverty reduction and Environment in the tropics. Washington: World Bank.

CIFOR 2011. Counting on the Environment. The contribution of forests to Rural Livelihoods, London: The Royal Society.

CLIRSEN 2003. La Deforestación en el Ecuador, Quito: Centro de Levantamientos Integrados de Recursos Naturales por Sensores Remotos.

COMTRADE 2011. Estadísticas de Comercio Exterior. Accessed 31 August 2011. legacy. intracen.org/marketanalysis/Default.aspx

Díaz F and Gatter S. 2004. Estudio Comparativo del Desperdicio y Costo de Cepillado y Canteado de la Madera Aserrada a Pulso Vs. Aserrada con Marco Guía, de la Especie Dacroydes Peruviana (Copal), Macas: SFA.

ECLAC 2011. Estadisticas de América Latina y el Caribe. Accessed 31 August 2011. http://websie.eclac.cl/infest/ajax/cepalstat. asp? carpeta $=$ estadisticas

Ecuador Forestal, 2007. Planeación Estratégica: Sub Sector Plantaciones Forestales Ecuador, Quito: CORPEI.

Espinoza G. 2005. Análisis económico de la cadena de aprovechamiento, transformación $y$ comercialización de tres productos de madera provenientes de bosques nativos de las regiones noroccidental y oriental del Ecuador., Quito: Colegio de Ingenieros Forestales de Pichincha CIFOP. 
FAO 1997. Las mujeres en la planificacion forestal del Ecuador, Quito: FAO.

FAO 2006. Andean Countries: An strategy for Forestry. Case Study: Ecuador, Rome: FAO.

FAO, 2010. Global Forest Resources Assessment. Rome: FAO.

FAO 2012. Estudios Sectoriales: Evaluación del cobro o derecho de aprovechamiento de madera y otras tasas sobre el manejo forestal, Rome: FAO.

FENOCIN; CNC, 2012. Ley Orgánica de Tierras y Territorios, Quito.

Gatter S and Romero M. 2005. Análisis Económico de la Cadena De Aprovechamiento, Transformación y Comercialización de Madera Aserrada Provenientes de Bosques Nativos en La Region Centro-Sur De La Amazonía Ecuatoriana, Macas: SFA.

Ghajar I and Najafi A. 2012. Evaluation of harvesting methods for Sustainable Forest Management (SFM) using the Analytical Network Process (ANP). Forest Policy and Economics, Volume 21, p. 81-91.

Gray C, Bilsborrow R, Bremner J and Lu F. 2008. Indigenous land use in the Ecuadorian Amazon: a cross-cultural and multilevel analysis. Human Ecology Journal, Volume 36, pp. 97-109.

Grijalva J et al. 2012. Situación de los Recursos Forestales Genéticos del Ecuador:: Quito.

Hansen CP. 2011. Forest Law compliance and enforcement: The case of on-farm timber extraction in Ghana. Journal of Environmental Management, Volume 92, pp. 575-586.

Hetsch S. 2004. La Comercialización de Madera en la Provincia de Pastaza.: Universidad de Friburgo.

Hetsch S. 2004. La Comercialización de Madera en la Provincia de Pastaza, Puyo: Universidad de Friburgo.

Holand MB et al. 2013. Complex Tenure and Deforestation: Implications for Conservation Incentives in the Ecuadorian Amazon. World Development.

Ibarra E, Romero M and Gatter S. 2008. Análisis del marco legal para el manejo forestal por pequeños productores rurales en la Amazonía ecuatoriana, La Paz: CIFOR, Servicio Forestal Amazónico.

INEC 2011. Encuesta de Superficie y Producción Agropecuaria Continua (ESPAC). Accessed 31 August 2012. www.ecuadorencifras.com/ cifras-inec/main.html
ITTO 2002. Tropical timber products Development of further processing in ITTO producer countries, Geneva: ITTO.

ITTO 2004. Consecución del Objetivo 2000 y la Ordenación Forestal Sostenible en Ecuador. Misión de Diagnóstico establecida conforme la Decisión 2(XXIX), Interlaken: ITTO.

ITTO 2011. Country Profile Ecuador, Yokohama: ITO (unpublished).

Izko X. 2009. Mecanismos Financieros para el Sector Forestal en el Ecuador, Quito: FAO, ITTO and OTCA.

Kaimowitz D. 2003. Forest law enforcement and rural livelihoods. International Forestry Review, 5(3), p. 199-210.

Kautz M. 2005. Aprovechamiento de la madera en el territorio Shuar de la Cordillera del Cóndor. Dresden University.

Key N, Sadoulet E and Janvry A. 2000. Transactions costs and agricultural household supply response. American Journal of Agriculture Economics, 82(2), pp. 245-259.

Kingman S. 2007. Áreas Protegidas y Pueblos Indigenas: Un Estudio de Caso en ECUADOR, Quito: FAO.

Kishor N and Damania R. 2009. Crimen y justicia en el Jardín del Edén: Mejorar la Gobernabilidad y Reducir la corrupción en el Sector Forestal. In: Múltiples Caras de la Corrupción. Washington DC: World Bank.

Lee D. 2005. Agricultural sustainability and technology adoption: Issues and policies for developing countries. American Journal of Agriculture Economics, 87(1325-1334), p. 5.

Li R and Buongiorno J. 2010. Long-term effects of eliminating illegal logging on the world forest industries, trade and inventory. Número 10.

MAGAP 2000. III Censo Nacional Agropecuario. Ministerio de Agricultura, Ganadería, Acuacultura y Pesca, Quito: Ministerio de Agricultura y Ganadería.

Mamo G, Sjaastad E and Vedeld P. 2007. Economic dependence on forest resources: A case from Dendi District, Ethiopia. Forest Policy and Economics Journal, Volume 9, pp. 916-927.

Mateo RG et al. 2013. A new spin on a compositionalist predictive modelling framework for conservation planning: A tropical case study in Ecuador. Biological Conservation, Issue 160, p. 150-161.

Mederski PS. 2006. A comparison of harvesting productivity and costs in thinning operations 
with and without midfield. Forest Ecology and Management, Volume 224, p. 286-296.

Medina G, Pokorny B and Campbell B. 2008. Favouring local development in the Amazon: Lessons from community forest management initiatives, Bogor: CIFOR.

Medjibe V P and Putz FE. 2012. Cost comparisons of reduced-impact and conventional logging in the tropics. Journal of Forest Economics, Volume 18, p. 242-256.

Mejía EK. 2010. La descentralización del ambiente en Ecuador, Fribourg: University of Fribourg.

Mena CF et al. 2011. Land use change on household farms in the Ecuadorian Amazon: Design and implementation of an agent-based model. Applied Geography, pp. 210-222.

Merino J. 2010. Estudio Económico de dos Formas de Aprovechamiento Forestal del Pigue (Pollalesta discolor) en el canton Mera, provincia de Pastaza., Riobamba: ESPOCH.

Meza JA. 2010. Los programas forestales nacionales en América del Sur: Política, legislación e institucionalidad - sistematización de la información, Santiago: FAO, Regional Office for Latin America and the Caribbean.

Middleton A. 2007. Globalization, Free Trade, and the Social Impact of the Decline of Informal Production: The Case of Artisans in Quito, Ecuador. World Development, 35(11), pp. 1904-1928.

Ministerio del Ambiente del Ecuador. 2006. El Sistema Nacional Descentralizado de Control Forestal, Sao Paulo: MAE.

Ministerio del Ambiente del Ecuador. 2006. Transparencia Forestal, Lima: MAE.

Ministerio del Ambiente del Ecuador. 2010. Reservas de Biosfera del Ecuador: lugares excepcionales, Quito, Ecuador: GTZI GESOREN/DED-WCS- NCI-UNESCO.

Ministerio del Ambiente del Ecuador. 2011. Descripción de las Cadenas Productivas de Madera en el Ecuador. Quito. 95p, Quito: MAE-ITTO.

Ministerio del Ambiente del Ecuador. 2011. Gobernanza Forestal en el Ecuador, Quito: MAE-ITTO.

Ministerio del Ambiente del Ecuador. 2011. Supervisión y Verificación de los Recursos Forestales en el Ecuador, Quito: MAE-ITTO.

Ministerio del Ambiente del Ecuador. 2012. Linea Base de Deforestación del Ecuador Continental, Quito: Ministerio del Ambiente.
Moser C and Barrett C. 2003. The disappointing adoption dynamics of a yield-increasing, low external-input technology: the case of SRI in Madagascar. Agricultural Systems, 76(3), pp. 1085-1100.

Navarro G, Gatto FD and Schroeder M. 2009. Sistema Ecuatoriano Tercerizado de Control Forestal, Turrialba: CATIE.

Nino ACB. 2010. Haciéndonos mi cuerpo: etnicidad, género y generación en un grupo napo kichwa. Quito: FLACSO.

Núñez AM. 2009. Estado de situación sobre las tierras indigenas y mujeres indigenas, La Paz: UNIFEM.

Owen R and Thiel H. 2006. Andean Countries: A Strategy for Forestry. Case Studies - Volume III of V. Ecuador., Rome: FAO/World Bank Cooperative Programme, Latin America and the Caribbean Service, Investment Centre Division.

Pacheco P. 2012. Smallholders and Communities in Timber Markets: Conditions Shaping Diverse Forms of Engagement in Tropical Latin America. Conservation and Society, 10(2), pp. 114-123.

Pacheco P, Barry D, Cronkleton P and Anne L. 2009. El papel de las instituciones informales en el uso de los recursos forestales, Bogor: CIFOR.

Pacheco P, de Jong W and Johnson J. 2010. The evolution of the timber sector in lowland Bolivia: examining the influence of three disparate policy approaches. Forest Policy and Economics, Volumen 12, pp. 271-276.

Palacios W. 2008. Análisis de la situación de la gobernabilidad y del cumplimiento de la legislación en el sector forestal en el Ecuador. Quito. Iniciativa para la aplicación de la legislación forestal en la Amazonía, Quito: ALFA-OTCA/MAE.

Palacios W and Malessa U. 2010. Situación de las comunidades productoras forestales de la Amazonía ecuatoriana: obstáculos y oportunidades para comercializar madera legal, Quito: TRAFFIC.

Pichon F. 1997. Colonist Land-Allocation Decisions, Land Use, and Deforestation in the Ecuadorian Amazon Frontier. Economic Development and Cultural Change, 45(4), pp. 707-744.

Pinedo-Vásquez M, et al. 2001. Post-Bool Logging in Amazonía. Human Ecology, 29(2), pp. 219-239. 
PNC ONU-REDD Ecuador, 2013. Programa de Naciones Unidas para la Reducción de las Emisiones por Deforestación y Degradación del Bosque en los Paises en Desarrollo Documento del Programa Nacional Conjunto, Quito: ONU.

Pokorny B and Johnson J. 2008. Community forestry in the Amazon: The unsolved challenge of forests and the poor. ODI.

Pokorny B, Johnson J, Medina G and Hoch L. 2012. Market-based conservation of the Amazonían forests: Revising win-win expectations. Geoforum, Volume 43, pp. 387-401.

Robles M. 2013. Incentivos en el sector forestal (interview, 20 March 2013).

Sadoulet E and Janvry A. 2005. Quantity Development Policy Analysis. Baltimore: The Johns Hopkins University Press.

Salazar F. 2006. Huaquillas es la puerta del comercio ilegal (Cámara de Comercio) (interview, 27 March 2006).

Schlotzhauer P. 2012. Value chain analysis of wood utilization from the standing tree to the final product inside the Cantón Tena, Ecuador, Fribourg: University of Fribourg.

SENPLADES 2009. Plan Nacional para el Buen Vivir 2009-2013: Construyendo un Estado Plurinacional e Intercultural, Quito: Secretaria Nacional de Planificación.

Sherbinin A d, et al. 2008. Rural household demographic, livelihoods and the environment. Global Environmental Change, Volume 18, pp. 38-53.

Sierra R. 2001. The role of domestic timber markets in tropical deforestation and forest degradation in Ecuador: Implications for conservation planning and policy. Ecological Economics, Issue 36, pp. 327-340.

Smith J, Colan V, Sabogal C and Snook L. 2006. Why policy reforms fail to improve logging practices: The role of governance and norms in Peru.

Southgate D, Salazar-Canelos P, Camacho-Saa C and Stewart, R., 2000. Markets, Institutions, and Forestry: The Consequences of Timber Trade Liberalization in Ecuador. 28(11).

Southgate D, Sierra R and Brown L. 1991. The Causes of Tropical Deforestation in Ecuador: A Statistical Analysis. World Development, 19(9), pp. 1145-1151.

Southgate D, Wasserstrom R and Reider S. 2009. Oil development, deforestation and indigenous populations in the Ecuadorian Amazon.
In Meeting of the Latin American Studies Association, Rio de Janeiro: LASA.

Spinellia R, Ward SM and Owende PM. 2099.

A harvest and transport cost model for Eucalyptus spp. fast-growing short rotation plantations. Biomass and bioenergy, Volume 33, p. 1265-1270.

Tandazo F and Gatter. 2004. Manual para el Manejo Forestal en Fincas.

Terán C. 2012. La industria forestal en el Ecuador, Quito.

Thiel $\mathrm{H}$ and Trelles M. 2008. Análisis Preliminar de la Aplicación de la Legislación Forestal en la Cuenca Amazónica, Quito: Organización del Tratado de Cooperación Amazónica.

Vásquez E. 2004. La Industria Forestal Del Ecuador, Quito: COMAFORS.

Vásquez E. 2011. Propuesta de un Plan de Mejora Competitiva Valorada de la Cadena de Madera Aserrada, Quito: Ministerio de Industrias y Productividad.

Vinueza M. 2012. La evolución del Sistema Nacional de Control Forestal (interview, 2012).

Viteri A, Cuenca P and Cordero V. 2010. Documento de Análisis del Sector Forestal en el Contexto De Adaptación y Mitigación sa Cambio Climático Del Sector Uso De Suelo, Cambio De Suelo, Y Silvicultura Forestal) En El Ecuador, Quito: UNDP.

Wit M, et al. 2010. Chainsaw milling: supplier to local markets - a synthesis. ETFRN News, Volume 52, pp. 7-27.

Wollni M. 2006. Coping with the Coffee Crisis; an Analysis of the Production and Marketing Performance of Coffee Farmers in Costa Rica. Development Economic and Policy, Volume 57, p. 173.

Wunder S. 1996. Los Caminos de la Madera. Una investigación de los usos domésticos y comerciales de los productos de la madera, y su relación con el proceso de deforestación, Quito: DDA, INTERCOOPERATION and IUCN.

Wunder S. 2000. The Economics of Deforestation: The Example of Ecuador, Basingstoke: Macmillan.

Wunder S. 2003. Ecuador. In: Oil Wealth and the Fate of the Forest. A comparative study of eight tropical countries. London: Routledge.

Wunder S. 2005. Macroeconomic Change, Competitiveness and Timber Production: A Five-Country Comparison. 33(1). 


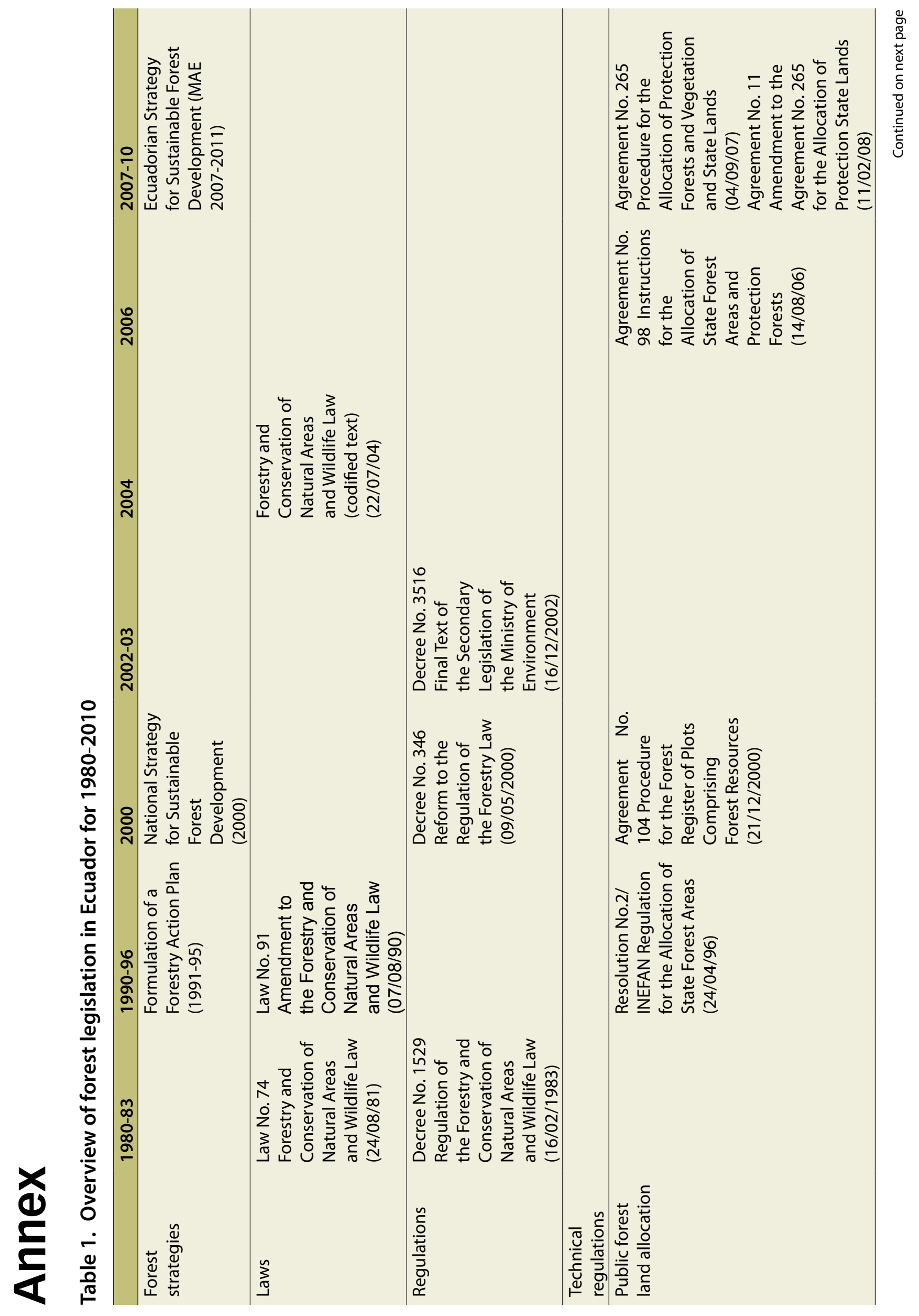




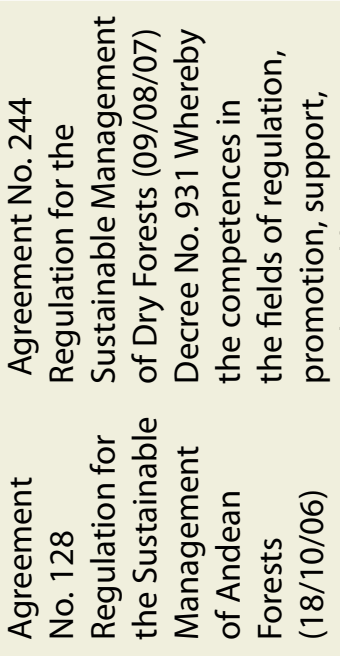

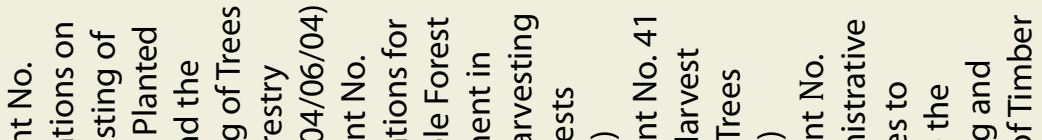

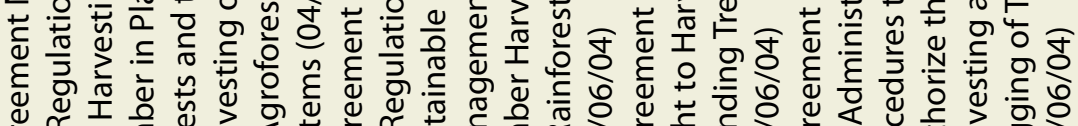

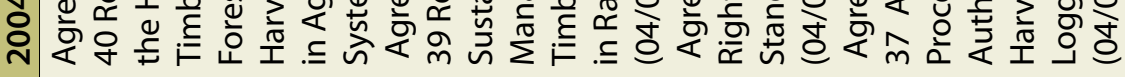

守导的 气

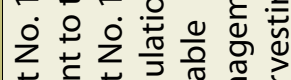

$m$ 要

กิ山

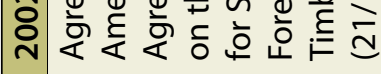

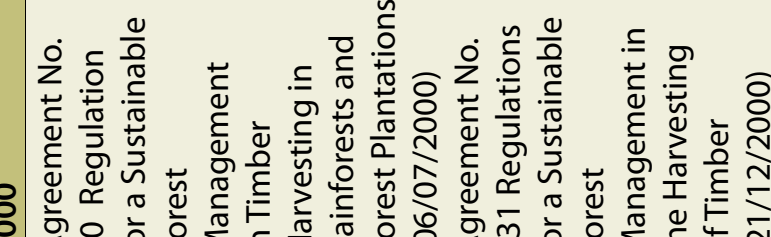

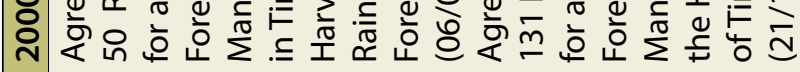

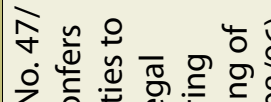

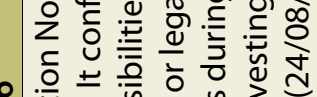

क人ำ

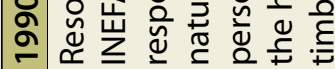

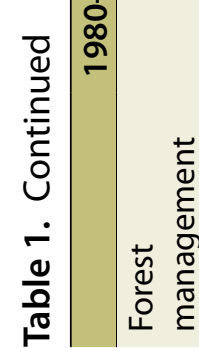




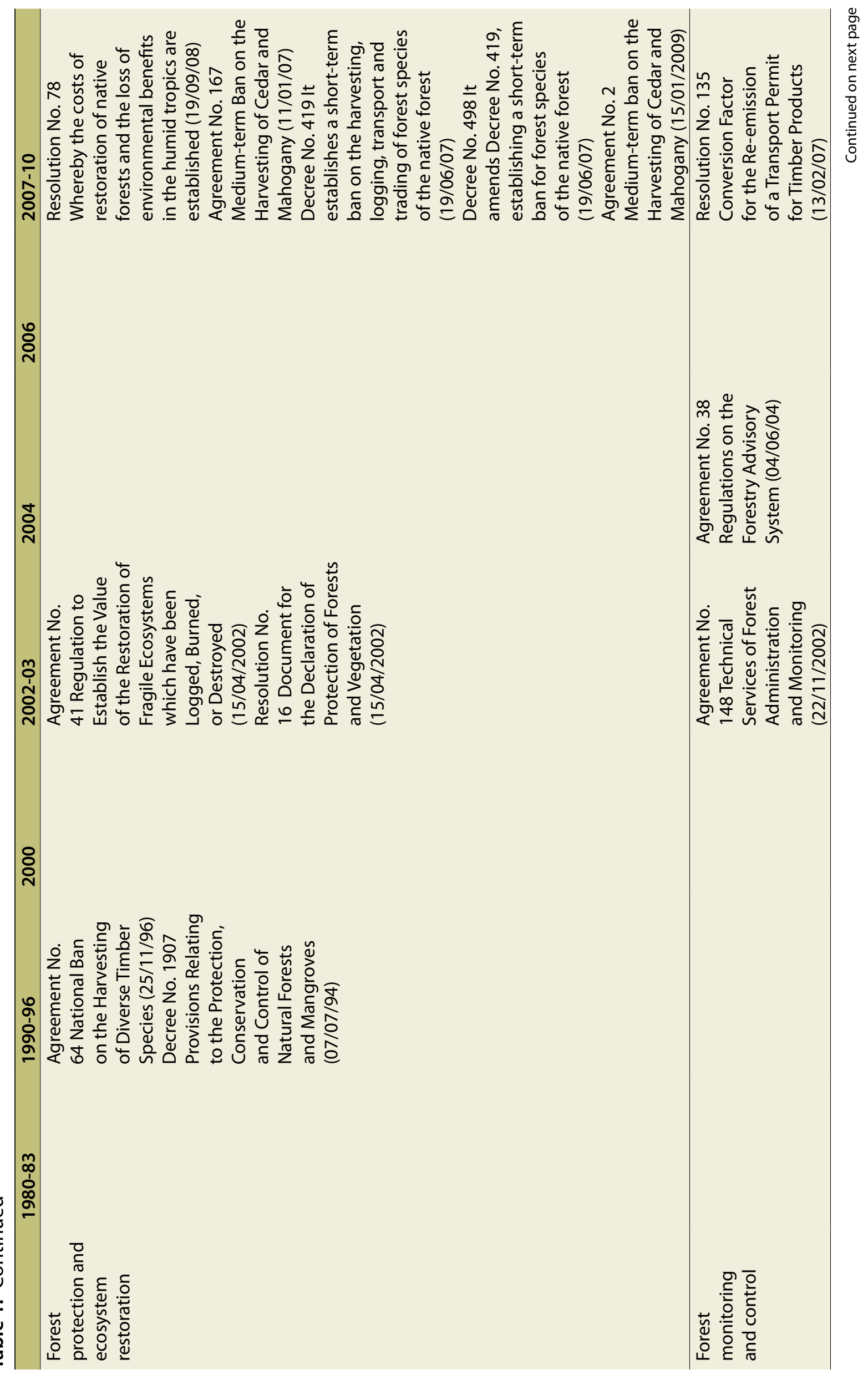




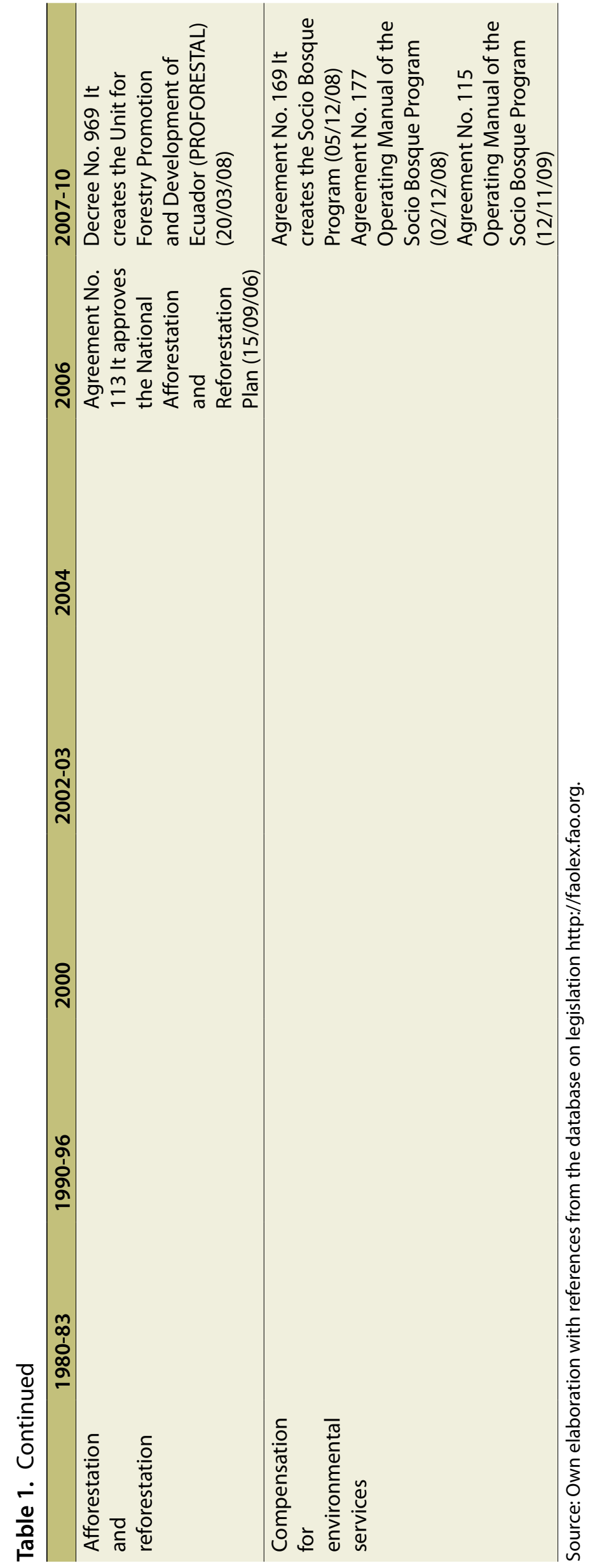



CIFOR Occasional Papers contain research results that are significant to tropical forest issues. This content has been peer reviewed internally and externally.

Ecuador is a rich country in natural resources, most of which are found in the Amazon. Timber is one of the most important resources obtained from native forests. Most of the timber is consumed in the domestic market, which has doubled during the past five years, and a smaller part is destined to a cross-border market, the size of which remains unknown. The timber harvested in the Amazon comes from forests of native communities located in rural smallholdings or farms. The smallholders sell their timber formally but also through informal operations. The timber intermediation networks in rural areas are handled by intermediaries who legalize the timber offered in the market through different mediums, while the urban markets are dominated by large processors and distributors. The growing urban demand also contributes to the informality due to the fact that the intermediaries are unable to supply all of the purchase orders with timber originating from legal harvesting. Timber harvesting is important because it contributes approximately $19 \%$ of the average total income of rural households and provides money in cash to these households to satisfy some basic needs of the family.

\begin{tabular}{|c|c|c|}
\hline CGIAR & $\begin{array}{l}\text { RESEARCH } \\
\text { PROGRAM ON } \\
\text { Forests, Trees and } \\
\text { Agroforestry }\end{array}$ & $\begin{array}{l}\text { This research was carried out by CIFOR as part of the CGIAR Research Program on Forests, Trees } \\
\text { and Agroforestry (CRP-FTA). This collaborative program aims to enhance the management and } \\
\text { use of forests, agroforestry and tree genetic resources across the landscape from forests to farms. } \\
\text { CIFOR leads CRP-FTA in partnership with Bioversity International, CATIE, CIRAD, the International } \\
\text { Center for Tropical Agriculture and the World Agroforestry Centre. }\end{array}$ \\
\hline
\end{tabular}
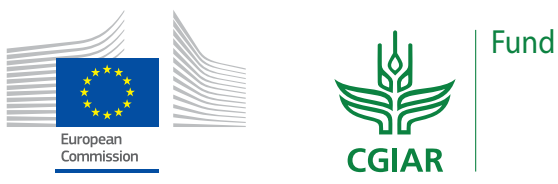